\title{
OVERLEGALIZING HUMAN RIGHTS: INTERNATIONAL RELATIONS THEORY AND THE COMMONWEALTH CARIBBEAN BACKLASH AGAINST HUMAN RIGHTS REGIMES
}

\author{
Laurence R. Helfer*
}

As the ratification of human rights treaties increases and the use of supranational adjudication to challenge human rights violations becomes more widespread, international legal scholars and international relations theorists alike have started to examine the effects of the increasing legalization of human rights norms. This Article raises the claim that international human rights law can become overlegalized, and it draws upon international relations theory and new empirical evidence to explore a recent case study of overlegalization. The Article seeks to understand why, in the late 1990s, three Commonwealth Caribbean governments denounced human rights agreements and withdrew from the jurisdiction of international human rights tribunals. It concludes that, while the denunciations can be viewed as arising from certain features unique to the Caribbean-in particular a dispute over capital punishment or judicial imperialism by the region's highest appellate court-they can also be understood as a response to the overlegalization of the governments' human rights commitments. In addition, the Article reassesses realist, ideational, and liberal international relations theories of treaty formation and compliance in light of the Caribbean case study, concluding that the notion of overlegalization adds nuance to the predictive power of these three theories.

\section{TABle of Contents}

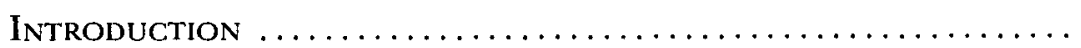

I. Legalization and the International Politics of Human Rights Treaties ................................ 1839

A. 1dentifying Legalization Variables in Human Rights Treaties ............................... 1839

B. International Relations Theories of Human Rights Treaty Formation ....................... 184I

C. International Relations Theories of Human Rights Treaty Compliance..........................

* Professor of Law and Lloyd Tevis Fellow, Loyola Law School, Los Angeles. Thanks to Ellen Aprill, Jeff Atik, David Boyd, Allison Danner, Graeme Dinwoodie, Catherine Fisk, John Knox, Kal Raustiala, Ted Seto, Beth Simmons, Anne-Marie Slaughter, and Lawrence Solum, who commented on earlier drafts or discussed specific issues raised in those drafts, to Kristopher Diulio, Loyola Class of 2003, for excellent research assistance, and to Jennifer Laurin of the Columbia Law Review for her exceptionally thoughtful review of the manuscript. Earlier versions of this paper were presented at the 2002 American Society of International Law Annual Meeting, the Political Study of International Law Speaker Series at UCLA Law School, and at faculty workshops at Arizona, Loyola, Melbourne, and USC law schools. 
1. 1deational Theory: The Spiral Model of Human Rights Change

2. Liberal Theory: The Role of lncorporation and Supranational Judicial Review in Securing Treaty Compliance

D. Human Rights Treaty Evolution and the Overlegalization of Human Rights .

1. Overlegalization that Changes Initial Treaty Bargains

2. Overlegalization that Improves Enforcement Opportunities .

E. The Causes and Consequences of Overlegalization:

A Preliminary Assessment ....................... 1858

11. The Human Rights Backlash in the Commonwealth

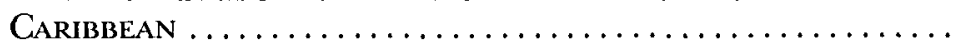

A. Political and Legal Systems and Efforts to Protect

Human Rights $\ldots \ldots \ldots \ldots \ldots \ldots \ldots \ldots \ldots \ldots$

1. Domestic Regime Types ...................

2. Domestic and International Protection of Human Rights

3. Domestic Legal Systems: The Role of the Privy Council .................................

B. Criminal Justice Systems and the Pratt Case ........ 1867

1. The Rise of Death Rows in the Caribbean ...... 1867

2. The Pratt Case ......................... 1869

3. The Domestic Effects of Pratt.............. 1872

4. The International Effects of Pratt ............ 1872

5. The International Response to Pratt.......... 1874

6. The Domestic Response to Pratt............. 1879

C. Severing Links to the Privy Council and Creating a New Caribbean Court of Justice ..................

D. Caribbean Human Rights Protections in the Twentyfirst Century

III. Viewing the Caribbean Backlash Through Three

Optics............................... 1886

A. The Caribbean Backlash as a Capital Punishment

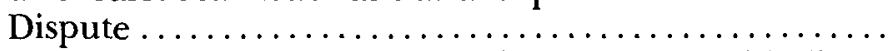

B. The Caribbean Backlash as a Consequence of Judicial Imperialism ............................ 1888

C. The Caribbean Backlash as Overlegalization of International Law ..........................

IV. Assessing Competing International Relations Theories in Light of the Caribbean Treaty Denunciations.......

A. Assessing Realist Theory .................... 1895

B. Assessing Ideational Theory .................. 1898

C. Assessing Liberal Theory .................... 1902

1. Differences in Regime Type as an Explanatory Variable ................................ 1902

2. Incorporation and Supranational Judicial Review as Explanatory Variables ....................... 1905 


\section{NTRODUCTION}

Questions of compliance dominate international human rights law. Although once the exclusive province of nonbinding norms with no clear avenues of enforcement, international human rights today is comprised of complex and constraining rules targeted at the heart of domestic legal systems. It contains precise and detailed requirements for governments, and it uses judicial or court-like dispute settlement mechanisms to which aggrieved private parties have direct access.' Strikingly, this progressive legalization ${ }^{2}$ of human rights has thus far appeared to meet with state approval. States have adhered to human rights treaties in increasing numbers, such that near universal ratification of many treaties is now plausible. ${ }^{3}$

Yet does the legalization of international human rights norms necessarily increase state compliance with those norms? Can human rights be "overlegalized," ${ }^{4}$ making their substantive rules or review mechanisms too constraining of sovereignty and precipitating a backlash by governments? If so, when are such counter-reactions likely to arise and how can they be avoided?

International legal scholars and international relations theorists answer these questions very differently. Within the legal academy, it is an article of faith that law matters. The international legal literature is replete with assertions that governments, albeit to greater or lesser degrees in different contexts, value their treaty commitments and alter their conduct to meet them. ${ }^{5}$ International legal scholars focus on success stories-well-publicized cases where compliance with treaty rules does occur and where domestic practices are altered as a result-and use those stories to extrapolate to conclusions about the overall efficacy of interna-

1. See Laurence R. Helfer, Forum Shopping for Human Rights, 148 U. Pa. L. Rev. 285, 288-89 (1999) (discussing history of international human rights petition system).

2. For a definition and discussion of "legalization," see infra Part I.A.

3. See United Nations, Economic and Social Council, Commission on Human Rights, Effective Functioning of Bodies Established Pursuant to United Nations Human Rights Instruments, Final Report on Enhancing the Long-term Effectiveness of the United Nations Human Rights Treaty System II 14-36, U.N. Doc. E/CN.4/1997/74 (1997) (noting "significant improvement" in progress toward universal ratification of the "core" U.N. human rights treaties and setting forth recommendations to encourage achievement of goal). Too much weight should not be placed on the increase in treaty ratifications, however. It has been argued that the "widespread ratification of human rights treaties masks widely varying normative views" about compliance with human rights norms. Kenneth W. Abbott, International Relations Theory, International Law, and the Regime Governing Atrocities in Interual Conflicts, 93 Am. J. Int'l L. 361, 373 (1999); see also Stephen D. Krasner, Sovereignty: Organized Hypocrisy 32 (1999) ("At Ieast until the 1990 s... the correlation between the behavior of governments with regard to human rights and the number of United Nations accords they had signed was weak.").

4. For a definition and detailed discussion of overlegalization, see infra Part I.D.

5. The most famous of these assertions is Louis Henkin's, that "almost all nations observe almost all principles of international kaw and almost all of their obligations almost all of the time." Louis Henkin, How Nations Behave 47 (2d ed. 1979) (emphasis omitted). 
tional law. These scholars also stress the evolutionary character of international law (and human rights law in particular), including its increasing number of regimes and institutions, its expansion to new settings and issue areas, and its penetration into national law. Only rarely do legal scholars seek to isolate the variables that contribute to compliance $^{6}$ or effectiveness, ${ }^{7}$ or to support their conclusions with empirical evidence. $^{8}$

By contrast, political scientists concerned with international legal regimes seek to develop empirically testable hypotheses about whether, and under what conditions, legal rules are effective in changing government behavior. These scholars also attempt to isolate the causal pathways by which compliance with those rules occurs. Most of the literature on these subjects is of a relatively recent vintage, ${ }^{9}$ and the empirical challenges (particularly in the human rights context) of measuring compliance are considerable. ${ }^{10}$ Yet international relations scholars have already generated a number of important theories about the relative importance of different explanatory variables (of which law is only one) in altering government conduct. Many of these hypotheses challenge, often fundamentally, the beliefs long held by international lawyers.

This Article lies at the intersection of international law and politics. It seeks to understand why, in the late 1990 s, three Commonwealth Caribbean governments denounced human rights treaties, including treaties granting jurisdiction to two international human rights tribunals. The denunciations followed a series of rulings by the region's highest appellate court, the Judicial Committee of the Privy Council, restricting the

6. For rare exceptions, see Benedict Kingsbury, The Concept of Compliance as a Function of Competing Conceptions of International Law, 19 Mich. J. Int'l L. 345, 346 (1998) (linking different conceptions of compliance to different theories "of the relations of law, behavior, objectives, and justice"); Kal Raustiala, Compliance \& Effectiveness in lnternational Regulatory Cooperation, 32 Case W. Res. J. lnt'l L. 387, 391-99 (2000) (defining distinct concepts of "compliance" and "effectiveness" and contrasting them with other concepts, such as "implementation").

7. One exception is Laurence R. Helfer \& Anne-Marie Slaughter, Toward a Theory of Effective Supranational Adjudication, 107 Yale L.J. 273, 298-336 (1997) (identifying three sets of variables that co-vary with effective supranational adjudication in Europe).

8. For a recent and significant exception, see Oona A. Hathaway, Do Human Rights Treaties Make a Difference?, 111 Yale L.J. 1935, 1940, 1962-2002 (2002) (presenting extensive quantitative analysis of states' human rights practices and concluding that "noncompliance with treaty obligations appears to be common" and that "treaty ratification is not infrequently associated with worse human rights ratings than otherwise expected").

9. For a comprehensive survey of this literature, see Kal Raustiala \& Anne-Marie Slaughter, International Law, lnternational Relations, and Compliance, in Handbook of International Relations 538, 539-45 (Walter Carlsnaes et al. eds., 2002).

10. E.g., Douglass Cassel, Does International Human Rights Law Make a Difference?, 2 Chi. J. Int'l L. 121, 122, 131 (2001) (noting that numerous variables influencing government behavior problematize empirical proof of human rights law's effectiveness); Hathaway, supra note 8 , at 1963-68 (discussing the challenges of measuring compliance with and effectiveness of human rights treaties through quantitative analysis). 
execution of criminal defendants who had filed petitions with the international tribunals alleging violations of their rights. I refer to the governments' withdrawals from these treaties and from the jurisdiction of these tribunals as the "Commonwealth Caribbean backlash" against human rights regimes. My study of this backlash has two objectives. The first is to show how overlegalizing human rights can lead even liberal democracies $^{11}$ to reconsider their commitment to international institutions that protect those rights. The second objective is to use the Caribbean example as a case study ${ }^{12}$ against which to test recent and competing international relations theories seeking to explain the conditions under which states comply with their treaty commitments.

The Commonwealth Caribbean backlash is intriguing on several levels. First, it runs counter to the largely progressive evolution of human rights law to date. ${ }^{13}$ It tells the story of an unprecedented "exit" 14 by liberal democratic governments from international human rights regimes, a withdrawal that includes formal (and likely permanent) treaty denunciations. ${ }^{15}$ Second, the case study describes a rich set of interactions between international jurists and their national counterparts. It thus adds to the growing literature that sees links between international tribunals and domestic courts as a key variable favoring treaty compliance. ${ }^{16}$ Third, the case study is non-European. Much of the research

11. For a list of the major characteristics shared by liberal democratic states, see infra note 45 .

12. For a discussion of the importance of case studies to international relations theories relevant to international lawyers, see Abbott, supra note 3, at 362-63.

13. See Cassel, supra note 10, at 126 (noting that "processes of rights protectionincluding human rights law-are . . growing stronger"); Helfer, supra note 1, at 289 (noting that "rich and nuanced case law" has developed in human rights tribunals).

14. J.H.H. Weiler, The Transformation of Europe, 100 Yale L.J. 2403, 2411-1 2 (1991) (asserting that member states' relinquishment of option to "exit" from European Community correlated with exercising of "voice" in Community governance (citing Albert O. Hirscbman, Exit, Voice and Loyalty: Responses to Decline in Firms, Organizations, and States (1970))).

15. Formal denunciations of human rights agreements or institutions are relatively rare (and often temporary) and generally have been carried out by nondemocratic governments. In 1999, for example, President Alberto Fujimori of Peru denounced the jurisdiction of the Inter-American Court of Human Rigbts. After Fujimori's exit from power and a return to democratic rule, Peru reacceded to the court's contentious jurisdiction in January 2001. Cassel, supra note 10 , at 128 . Greece followed a similar pattern in the early 1970s, withdrawing from the Council of Europe and its human rights system after a military coup and rejoining after a return to democracy. Kathryn Sikkink, The Power of Principled ldeas: Human Rights Policies in the United States and Western Europe, in Ideas and Foreign Policy: Beliefs, Institutions, and Political Change 130, 149-50 (Judith Goldstein \& Robert O. Keohane eds., 1993). North Korea denounced the International Covenant on Civil and Political Rights (ICCPR) in 1997. Letter from Kim Yong Nam, Minister of Foreign Affairs, North Korea, to Kofi Annan, Secretary-General, United Nations (Aug. 23, 1997) (on file with the Columbia Law Review).

16. See, e.g., Karen Alter, The European Union's Legal System and Domestic Policy: Spillover or Backlash?, 54 lnt'l Org. 489, 492 (2000) (asserting that "many if not most of the advances in European law have been the result of national courts referring preliminary 
touting the efficacy of international law focuses on Europe, a region whose treaty regimes and international courts are among the most advanced and effective in existence. ${ }^{17}$ Study of a non-European exemplar, particularly one rich in cross-court relationships, tests the robustness of theories developed in one region in other parts of the world. Fourth and finally, the case study is based on new empirical evidence. It incorporates detailed data on changing patterns in the filing and review of international human rights petitions against Commonwealth Caribbean governments during the 1990s, data that allow for a deeper assessment of the backlash's causes.

Before proceeding, however, a cautionary note is in order. The case study does not identify any single variable or set of variables that conclusively explains the actions of Commonwealth Caribbean governments. The complex series of events leading to the treaty denunciations does not so easily lend itself to such definitive causal conclusions. In addition, the study contains a number of specific features-such as the prominence of differing views over capital punishment, and appellate review by a national court located in a foreign jurisdiction-that are unlikely to recur in other contexts.

But if the details are unique to the Commonwealth Caribbean, the study has important implications for international law and international relations generally. It suggests that states precisely calibrate the legalized quality of treaty regimes to achieve particular objectives. Seen from this perspective, the legalization of international commitments is not unambiguously good, and overlegalized treaty regimes may pose particular dangers. Consider the World Trade Organization (WTO) as an example. ${ }^{18}$ When it was launched in 1995, scholars praised the victory of trade "legalists," who trumpeted the WTO's sanctions-based dispute settlement system as an improvement over its more "diplomatic" predecessor (the

rulings to the [European Court of Justice (ECJ)]"); Helfer \& Slaughter, supra note 7, at 309 (explaining that the ECJ and the European Court of Human Rights (ECHR) have increased their effectiveness in part by crafting their opinions to appeal to both the material interests and professional ideals of national courts and prospective litigants); Anne-Marie Slaughter, Judicial Globalization, 40 Va. J. 1nt'l L. 1103, 1104-12 (2000) [hereinafter Slaughter, Judicial Globalization] (describing process by which the ECJ and ECHR reviewed complaints arising from domestic legal settings and enhanced states' compliance with European Community treaties and the European Convention on Human Rights).

17. See John H. Barton \& Barry E. Carter, The Uneven But Growing Role of International Law, in Rethinking America's Security: Beyond Cold War to New World Order 279, 287 (Graham Allison \& Gregory F. Treverton eds., 1992) (describing judgments of the European Court of Human Rights as being "as effective as those of any domestic court"); see also Helfer \& Slaughter, supra note 7, at 293-97 (describing the docket of the ECHR as "relatively teeming" and noting that "the rate of compliance by states with the ECHR's rulings is extremely high").

18. Final Act Embodying the Results of the Uruguay Round of Multilateral Trade Negotiations, Apr. 15, 1994, Legal lnstruments-Results Of The Uruguay Round vol. 1 (1994), 33 l.L.M. 1140 (1994) [hereinafter Final Act]. 
General Agreement on Tariffs and Trade (GATT)). ${ }^{19}$ Seven years on, the case for strongly legalized trade regimes is more uneasy. Governments do not habitually alter their domestic laws to comply with WTO rulings. And one of the remedies for noncompliance-retaliatory sanctions-causes the very trade distortions that the WTO was designed to avert. ${ }^{20}$ The Caribbean backlash suggests that patterns of overlegalization can also develop for international human rights-an area that, paradoxically, is often viewed as underlegalized. ${ }^{21}$

The Caribbean backlash also generates important insights for international legal and international relations scholars. For political scientists, the case study provides an opportunity to test and refine competing arguments. Each of three major theoretical approaches-realist, ideational, and liberal-that seek to explain why states create and enforce legalized human rights regimes offers insights into why Caribbean states abrogated their treaty commitments. But no single theory offers a complete explanation, and the evidence presented here challenges hypotheses that each theory has advanced. For international legal scholars, the case study raises important issues of treaty structure, of international tribunals' appropriate functions, and of the role of state and nonstate actors in implementing treaty obligations.

The remainder of this Article proceeds as follows. Part I reviews the international relations literature on legalization and applies it in the context of human rights. 1t then describes three international relations theories-realist, ideational, and liberal-that offer competing hypotheses to explain why states enter into legalized commitments to protect human rights, the conditions under which states comply with those commitments, and the mechanisms by which human rights regimes evolve from their origins. Part 1 also introduces the contention that human rights agreements can become overlegalized, generating domestic opposition to a state's international obligations and pressure to exit from a treaty. It identifies two distinct types of overlegalization and undertakes a preliminary assessment of what causes human rights treaties to become more highly legalized.

19. See G. Richard Shell, Trade Legalism and International Relations Theory: An Analysis of the World Trade Organization, 44 Duke L.J. 829, 833-34 (1995).

20. See Judith Goldstein \& Lisa L. Martin, Legalization, Trade Liberalization, and Domestic Politics: A Cautionary Note, 54 Int'l Org. 603, 620-21, 630 (2000) (arguing that the WTO's highly legalized rules may be suboptimal at achieving progressive liberalization of international trade); see also Steve Charnovitz, Rethinking WTO Trade Sanctions, 95 Am. J. Int'l L. 792, 792 \& n.2 (2001) (asserting that trade sanctions "undermine[ ] the [WTO] trading system" and proposing "softer measures" as alternatives).

21. See Christine M. Chinkin, Book Review, 95 Am. J. Int'l L. 472, 473 (2001) (reviewing Human Rights in Glohal Politics (Tim Dunn \& Nicholas Wheeler eds., 1999)) (" $[\mathrm{H}]$ uman rights activists and their organizations have invested significant resources in a strategy of legality - that is, a belief that claims are strengthened when encapsulated in law."). 
Part II reviews the political, legal, and historical commonalities shared by Commonwealth Caribbean states, including their domestic regime types, their support of international human rights institutions, and their retention of the Judicial Committee of the Privy Council as their highest court of appeal. Part II then sets out a brief narrative of the events leading to the Caribbean backlash against human rights treaties, human rights tribunals, and the Privy Council. It identifies the relationships among domestic and international state and nonstate actors and provides data concerning the filing and review of petitions with human rights tribunals during the 1990s.

Part III views the Caribbean backlash through three different optics-one focused on capital punishment, the second addressing the judicial imperialism of the Privy Council, and the third emphasizing the overlegalization of human rights obligations-and explores the broader implications of analyzing the case study from these perspectives.

Part IV reviews the case study using the three international relations theories discussed in Part I. It identifies features of the Caribbean backlash that each theory helps to explain, as well as aspects where the case study questions existing hypotheses.

\section{Legalization and the International Politics of Human Rights Treaties}

\section{A. Identifying Legalization Variables in Human Rights Treaties}

International relations theories relating to human rights regimes are one component of a broader debate about the role of law in world politics. In a series of recent studies, a number of prominent scholars analyzed why international regimes and institutions in a number of issue areas are increasingly "legalized." 22 These scholars reject any suggestion that governments face a binary choice between legalized and nonlegalized norms, and instead measure legalization using three variables: obligation, precision, and delegation. "Obligation" refers to the binding nature of an institution's or a regime's rules; "precision" refers to the specificity of those rules; and "delegation" refers to the authority granted to neutral third parties to interpret and implement those rules, to resolve disputes relating to them, and (sometimes) to create new rules. ${ }^{23}$

These three components of legalization are not fixed; each may vary independently of the others, both within a single regime and across different regimes. Consider a few examples of these components in the

22. Judith Goldstein et al., Introduction: Legalization and World Politics, 54 Int'l Org. 385, 393-96 (2000).

23. Kenneth W. Abbott et al., The Concept of Legalization, 54 1nt'l Org. 401, 401 (2000). 
human rights context, ${ }^{24}$ beginning with obligation. Human rights norms are found in instruments ranging from nonbinding documents, such as the Helsinki Accords, ${ }^{25}$ to legally binding conventions and treaties, such as the American Convention on Human Rights (American Convention) or the International Covenant on Civil and Political Rights (ICCPR).$^{26}$ Within a single treaty system, some agreements are binding while others (both substantive and procedural) are optional or merely hortatory. States parties to the American Convention, for example, must comply with that treaty's substantive rules, but have the choice of whether to ratify the Protocol to Abolish the Death Penalty, or to recognize the jurisdiction of Inter-American Court of Human Rights. ${ }^{27}$ Variations in obligation also exist among the decisions of international tribunals. Some decisions, such as those of the Inter-American Court, are legally binding; ${ }^{28}$ others, such as those of the Inter-American Commission on Human Rights and the U.N. Human Rights Committee, are not. ${ }^{29}$

Precision differs widely across all human rights instruments, often varying inversely with levels of obligation. The soft law Helsinki Accords contain very clear and detailed rules, for example, while the hard law International Covenant on Economic, Social and Cultural Rights contains far more ambiguous prescriptions for government conduct. ${ }^{30}$ Even

24. Non-human rights examples of these variations can be found in Kenneth $W$. Abbott \& Duncan Snidal, Hard and Soft Law in International Governance, 54 Int'l Org. $421(2000)$.

25. Conference on Security and Co-operation in Europe, Aug. 1, 1975, 14 I.L.M. 1292.

26. American Convention on Human Rights, Nov. 22, 1969, S. Exec. Doc. F, 95-2, at 41 (1978), 1144 U.N.T.S. 144 (entered into force July 18, 1978) [hereinafter American Convention]; International Covenant on Civil and Political Rights, adopted Dec. 19, 1966, S. Exec. Doc. E, 95-2, at 23 (1978), 999 U.N.T.S. 171 (entered into force Mar. 23, 1976) [hereinafter ICCPR].

27. American Convention, supra note 26, art. 62, S. Exec. Doc. E, 95-2, at 58, 1144 U.N.T.S. at 159; Protocol to the American Convention on Human Rights to Abolish the Death Penalty, June 8, 1990, 29 I.L.M. 1447.

28. American Convention, supra note 26, art. 68(1), S. Exec. Doc. E, 95-2, at 59, 1144 U.N.T.S. at 160 ("The States Parties to the Convention undertake to comply with the judgment of the Court in any case to which they are parties.").

29. See Optional Protocol to the International Covenant on Civil and Political Rights, adopted Dec. 19, 1996, art. 5(4), 999 U.N.T.S. 302, 303 (entered into force Mar. 23, 1976) [hereinafter Optional Protocol] (referring to decisions of the U.N. Human Rights Committee as "views"); Caballero Delgado \& Santana Case, Inter-Am. Ct. H.R. 135, 154, OAS/Ser.L/V/III.33, doc. 4 (1995) (holding that a "recommendation" issued by the InterAmerican Commission under articles 50 and 51 of the American Convention "does not have the character of an obligatory judicial decision for which the failure to comply would generate State responsibility"); see also Christina M. Cerna, International Law and the Protection of Human Rights in the Inter-American System, 19 Hous. J. Int'l L. 731, 752 (1997) (stating that the "[1nter-American Commission's] recommendations are not obligatory and the State may chose to comply or ignore them as it chooses"); Helfer \& Slaughter, supra note 7, at 351 (discussing expressly nonbinding nature of Committee's decisions).

30. Compare, e.g., Conference on Security and Co-operation in Europe, supra note 25 , pt. VII (stating that " $[\mathrm{s}]$ tates will recognize and respect the freedom of the individual to 
within a single human rights treaty, some provisions are vague, such as the collective right to self-determination, while others are unequivocal and clear-cut, such as the bans on slavery and torture. ${ }^{31}$

Levels of delegation in human rights instruments are also extremely diverse. Most human rights treaties contain their own independent monitoring mechanisms to review states' compliance with their international commitments. These mechanisms take many forms, ranging from fully adversarial courts to nonadversarial managerial bodies, with many gradations in between. A large number of treaties contain some kind of judicial or court-like procedure for individuals and private parties to bring complaints alleging violations of their treaty rights against governments. ${ }^{32}$

The degree to which human rights treaties are legalized across each of these three elements is, at least initially, a function of state preferences. States consciously design human rights agreements in response to specific problems, choosing the degrees of obligation, precision, and delegation required to solve those problems. ${ }^{33}$ But legalization is not costless. To the contrary, greater legalization necessarily requires a more farreaching diminution of sovereignty, raising the important question of what motivates states to create legalized human rights agreements in the first place.

\section{B. International Relations Theories of Human Rights Treaty Formation}

As Andrew Moravcsik has noted, human rights law is different from most other forms of institutionalized international cooperation. ${ }^{34}$ lt is primarily intended not to regulate the external interactions of states but

profess and practise, alone or in community with others, religion or belief acting in accordance with the dictates of his own conscience"), with International Covenant on Economic, Social and Cultural Rights, adopted Dec. 16, 1966, art. 2(1), S. Exec. Doc. D, 952, at 13 (1978), 993 U.N.T.S. 3, 5 (entered into force Jan. 3, 1976) (obligating states parties "to take steps . . . to the maximum of its available resources, with a view to achieving progressively the full realization of the rights recognized in the present Covenant").

31. Compare, e.g., ICCPR, supra note 26, art. 1(1), S. Exec. Doc. E, 95-2, at 23, 999 U.N.T.S. at 173 ("All peoples have the right of self-determination."), with id. art. 8(1), S. Exec. Doc. E, 95-2, at 25, 999 U.N.T.S. at 175 ("No one shall be held in slavery; slavery and the slave-trade in all their forms shall be prohibited."). For other examples, see Ellen L. Lutz \& Kathryn Sikkink, International Human Rights Law and Practice in Latin America, 54 Int'l Org. 633, 633-39 (2000) [hereinafter Lutz \& Sikkink, International Human Rights Law] (discussing levels of obligation, precision, and delegation of torture, disappearances, and democracy in Latin America).

32. See Helfer, supra note 1, at 296-98 (discussing courts, tribunals, and treaty bodies that review human rights complaints under.U.N.-based and regional human rights treaties).

33. Raustiala and Slaughter refer to these choices as a regime's "problem structure" and "solution structure." Raustiala \& Slaughter, supra note 9, at 545.

34. Andrew Moravcsik, The Origins of Human Rights Regimes: Democratic Delegation in Postwar Europe, 54 Int'l Org. 217, 217 (2000) [hereinafter Moravcsik, Origins]. 
rather to hold governments accountable for conduct occurring within their own borders. Moreover, human rights law often empowers the objects of its protection-individuals, groups, and private parties-to enforce legal commitments through international courts and quasi-judicial bodies. These two features make human rights treaties a particularly deep form of international agreement.

Three different theories-realist, ideational, and liberal-provide different answers to the question of why states seek to create intrusive and legalized international commitments. ${ }^{35}$ According to realist theorists, these commitments, including their review and enforcement institutions, are nothing more than a reflection of states' power and interests. Treaties and international organizations are thus of little concern to realists because they do not impose constraints on hegemonic states. ${ }^{36}$ Realists' focus on power as the currency of international affairs does, however, offer an explanation for why nonhegemonic states ratify human rights treaties. Weaker governments "accept international obligations because they are compelled to do so by great powers." 37 The latter, seeking to export their ideological preferences and further their own political interests, coerce weaker states to join human rights agreements. Conversely, where powerful states oppose progressive human rights policies, realist theory holds that they can block the formation of human rights commitments by other nations. ${ }^{38}$

An ideational theory of human rights law stands on a very different footing. 1t posits that the source of human rights commitments "lie[s] not solely in preexisting state or societal interests but in strongly held principled ideas (ideas about right and wrong)." 39 These ideas exert their own persuasive power that shapes the interests and identity of both state and nonstate actors. ${ }^{40}$ They also lead governments to create legalized commitments affirming the salience of the principles they embody and confirming collective legitimation on like-minded nations.

Liberal theory emphasizes states' rational pursuit of national interests, interests which reflect the preferences of their component constituencies and the "domestic and transnational social context in which they

35. For more extended discussions of these three theories, see id. at 220-29; Ellen Lut\% \& Kathryn Sikkink, The Justice Cascade: The Evolution and Impact of Foreign Human Rights Trials in Latin America, 2 Chi. J. Int'l L. 1, 5-7 (2001) [hereinafter Lutz \& Sikkink, Justice Cascade].

36. See Kenneth W. Abbott \& Duncan Snidal, Why States Act Through Formal International Organizations, 42 J. Conflict Resol. 3, 8 (1998) (noting this point, but stating that realist theorists underestimate the importance of international organizations, even to powerful states).

37. Moravcsik, Origins, supra note 34 , at 221.

38. See Lutz \& Sikkink, Justice Cascade, supra note 35, at 6.

39. 1d. at 5; see also Sikkink, supra note 15, at 140 (arguing that "[o]ne cannot understand the emergence and adoption of human rights policies ... without taking into account the unmediated role of ideas").

40. Lut\% \& Sikkink, Justice Cascade, supra note 35, at 5. 
are embedded." 41 It asserts that governments bind themselves to human rights commitments to reduce the political uncertainty that is an inevitable byproduct of popular sovereignty. According to one leading liberal theorist, nascent democracies are acutely sensitive to this uncertainty and to the possibility of nondemocratic retrenchment. It is they, rather than established democracies, who press for international commitments and judicial review as a means of "locking in' democratic rule through the enforcement oi human rights." 42

A key concept shared by both liberal and ideational scholars is a focus on the state as a transparent entity composed of disaggregated governmental and nongovernmental actors, each with its own distinct functions and interests. ${ }^{43}$ The diverse and often divergent preferences of these actors allow for a rich series of domestic and transnational interactions. But the very fact that these parties act with at least nominal independence says much about the political structures in which they are embedded. For if a state is controlled by a totalitarian or other nondemocratic political authority, these actors (to the extent they exist at all) will have little or no ability to oppose the forces exercising political power. Thus, liberal theory, and to a lesser degree ideational theory, attach critical importance to domestic regime type as a predictor of a state's behavior and of its interactions with other states and international institutions. ${ }^{44}$ States' status as liberal democracies ${ }^{45}$ or rule of law socie-

41. Andrew Moravcsik, Taking Preferences Seriously: A Liberal Theory of International Politics, 51 lnt'l Org. 513, 513 (1997); see also Jose E. Alvarez, Interliberal Law: Comment, 94 Am. Soc'y lnt'l L. Proc. 249, 253 (2000) (describing liberal theory's "central insight" as "investigating the complex consequences of the disaggregated state"); Anne-Marie Slaughter, A Liberal Theory of International Law, 94 Am. Soc'y Int'l L. Proc. 240, 241 (2000) [hereinafter Slaughter, Liberal Theory] (stating that characteristics of liberal theory include its bottom-up view, its linking of the international and domestic spheres, its rendering of state-society relations as transparent, and its transformation of states into governments).

42. Moravcsik, Origins, supra note 34, at 228. Other commentators have questioned whether this hypothesis about a human rights treaty's supporters holds outside of Europe. See, e.g., Lutz \& Sikkink, Justice Cascade, supra note 35, at 7 (questioning the hypothesis for Latin America).

43. This focus on disaggregation is not shared by realist theorists. But even for realists, the exporting of human rights policies by hegemonic states is undertaken by particular governmental subunits (i.e., the executive or legislative branch), whose actions, in turn, place pressure on other governmental subunits within weaker target states.

44. See Slaughter, Liberal Theory, supra note 41, at 249 ("Liberal international relations theory insists that differences in domestic regime type drive differences in positive behavior. Thus ... [there is a] distinction between liberal and non-liberal states as a positive predictor of how states are likely to behave . . . within or toward international institutions.").

45. See, e.g., Michael W. Doyle, Kant, Liberal Legacies, and Foreign Affairs, 12 Phil. \& Pub. Aff. 205, 207-09 (1983) (defining liberal democracies as having four major characteristics: (1) protection of private property; (2) a market economy; (3) equality under the law and respect for human rights; and (4) a representative government deriving its authority from the consent of individuals); Anne-Marie Slaughter, International Law in a World of Liberal States, 6 Eur. J. Int'l L. 503, 511 (1995) (defining a liberal democracy as 
ties $^{46}$ has thus featured prominently in recent international relations scholarship relating to human rights and other legalized international commitments. ${ }^{47}$

\section{International Relations Theories of Human Rights Treaty Compliance}

Although each of the three international relations theories seeks to explain why states negotiate new human rights treaties, none of them alone conclusively predicts how states will act once a human rights regime has been established. States face a number of critical choices with respect to such extant regimes. These choices include whether to join a treaty already binding on other nations; whether to ratify optional or supplemental treaty provisions, such as those allowing for judicial or quasi-judicial review; whether to comply with agreed-to commitments; and whether to formally exit from a treaty.

International relations scholars recognize the inadequacy of existing theories fully to explain these issues. Thus, a recent study offering a liberal explanation for the creation of the European Convention on Human Rights (European Convention) acknowledges that "the determinants of the evolution of human rights regimes are unlikely to be identical to the determinants of their founding and are therefore unlikely to be explained entirely by republican liberal theory." 48 In a similar vein, in a study of human rights trials in Latin America, two ideational scholars state that they "do not know with certainty what motivated" newly democratic governments in that region rapidly to ratify existing human rights agreements, and they note that the historical evidence supports all three theoretical perspectives. ${ }^{49}$

a state that possesses "some form of representative government secured by the separation of powers, constitutional guarantees of civil and political rights, juridical equality, and a functioning judicial system dedicated to the rule of law").

46. See Beth A. Simmons, The Legalization of International Monetary Affairs, 54 lnt'1 Org. 573, 595 (2000) [hereinafter Simmons, Legalization] (arguing that states complying with the "rule of law" have strong court systems, stable political institutions, an established framework of property rights, and an orderly system of succession).

47. See Andrew Moravcsik, Explaining International Human Rights Regimes: Liberal Theory and Western Europe, 1 Eur. J. Int'l Rel. 157, 179-80 (1995) [hereinafter Moravcsik, Explaining] (arguing that certain features of liberal regime types were essential preconditions for success of European human rights system and comparing features of regime types found in Latin America); see also Robert $O$. Keohane et al., Legalized Dispute Resolution: Interstate and Transnational, 54 Int'l Org. 457, 478 (2000) (positing that liberal democracies will be most receptive to efforts to "embed international law in domestic legal systems”); Simmons, Legalization, supra note 46, at 597-98 (presenting results of empirical research supporting premise that compliance with international monetary obligations is more likely for rule of law states than for liberal states); Beth A. Simmons, Capacity, Commitment and Compliance: International Institutions and Territorial Disputes 17-18 (2002) (unpublished manuscript, on file with the Columbia Law Review) (examining hypothesis that domestic regime type is an indicator of the likelihood of Latin American states submitting territorial disputes to arbitration).

48. Moravcsik, Origins, supra note 34 , at 246.

49. Lutz \& Sikkink, Justice Cascade, supra note 35 , at 7 . 
In seeking to discern how governments behave with regard to extant human rights agreements, recent international relations scholarship has reviewed the complex mechanisms by which state and nonstate actors interact within and across borders. Ideational and liberal scholars in particular have made significant contributions to identifying the causal pathways by which compliance occurs. ${ }^{50}$

1. Ideational Theory: The Spiral Model of Human Rights Change. Leading ideational scholars have developed a five-step " 'spiral model' of human rights change" that helps to explain compliance with human rights agreements. ${ }^{51}$ ln seeking to discern the forces that drive change at each stage of the spiral, ${ }^{52}$ these scholars look both within the state and outside it. Internally, ideationalists focus on domestic nongovernmental organizations, which act as "compliance constituencies" to pressure government officials to adhere to international commitments. ${ }^{53}$ Externally, these theorists highlight the importance of "transnational advocacy networks" or "principled issue-networks" comprised of concerned individuals, groups, and domestic and international government agencies and of-

50. Realist scholars have yet to respond to these ideational and liberal contributions. In part, this may result from a lack of interest in agreements that (realists assert) merely reflect rather than constrain state power. Because of such power, treaty compliance is merely a coincidence and can in fact be explained by a state acting in its self interest. See Hathaway, supra note 8 , at 1944-46. Notwithstanding the absence of recent realist efforts to explain compliance with human rights agreements, this Article considers a realist explanation for the Caribbean backlash in infra Part IV.A.

51. See Thomas Risse \& Kathryn Sikkink, The Socialization of International Human Rights Norms into Domestic Practices: Introduction, in The Power of Human Rights: International Norms and Domestic Change 1, 17-35 (Thomas Risse et al. eds., 1999) [hereinafter The Power of Human Rights].

52. In the first two stages of the spiral, states respond to domestic pressure for rights protections by repressing local advocacy groups, denying the validity of international jurisdiction, and asserting the counternorm of national sovereignty. Domestic nonstate actors also begin to forge links with transnational human rights networks during these early periods, allowing for increasing external pressure on state actors. Id. at 22-24. During the third stage of the spiral, governments begin to make minor "tactical concessions" in response to these internal and external pressures. Although governments often believe these concessions to be cosmetic or inconsequential, the discursive practices of advocacy groups entrap governments in their own rhetoric and initiate a dialogue that eventually changes both minds and interests. 1d. at 25-28. The spiral's fourth stage occurs when human rights norms acquire "prescriptive status." States acknowledge the validity of human rights norms, internalize them into their domestic legal systems, and ratify international agreements protecting individual rights. Id. at $29,31,33$. In the fifth and final stage of the spiral, governments engage in behavior that conforms to the international rules they have recognized and internalized, and pressure for change by nongovernmental organizations declines. Id. at 33. For additional discussion of the fourth and fifth stages of the spiral model as they relate to treaty ratification and treaty compliance, see infra notes $62-65$ and accompanying text.

53. See Miles Kahler, Conclusion: The Causes and Consequences of Legalization, 54 Int'l Org. 661, 675 (2000) (reviewing conclusions of other studies); see also Goldstein \& Martin, supra note 20, at 614-15 (discussing nonstate domestic actors favoring and opposing compliance with international trade agreements). 
ficials, who work together to solve human rights problems. ${ }^{54}$ Linking up with these transnational networks, domestic compliance constituencies create "boomerang" patterns of influence ${ }^{55}$ on "vulnerable" states ${ }^{56}$ by pressuring government officials " from above' and 'from below.' "57 Also central to ideationalist theory are "norm cascades," collections of normaffirming events that lead states rapidly to conform their conduct to international standards and implement those standards in their domestic legal systems. $^{58}$ Once these norm cascades evolve beyond their tipping

54. See Margaret E. Keck \& Kathryn Sikkink, Activists Beyond Borders: Advocacy Networks in International Politics 1 (1998); Kathryn Sikkink, Human Rights, Principled Issue-Networks, and Sovereignty in Latin America, 47 lnt'l Org. 411, 415-16 (1993); see also Peter M. Haas, Introduction: Epistemic Communities and International Policy Coordination, 46 lnt'l Org. 1, 3 (1992) (defining the related concept of "epistemic communities" as "network[s] of professionals with recognized expertise and competence in a particular domain and an authoritative claim to policy-relevant knowledge within that domain or issue-area").

55. According to Risse and Sikkink:

A "boomerang" pattern of influence exists when domestic groups in a repressive state bypass their state and directly search out international allies to try to bring pressure on their states from outside. National opposition groups, NGOs, and social movements link up with transnational networks and INGOs [international nongovernmental organizations] who then convince international human rights organizations, donor institutions, and/or great powers to pressure norm-violating states.

Risse \& Sikkink, supra note 51, at 18; see also Keck \& Sikkink, supra note 54, at 12-13 (describing operation of the boomerang pattem of influence).

56. Keck \& Sikkink, supra note 54, at 29 ("Vulnerability arises both from the availability of leverage and the target's sensitivity to leverage; if either is missing, a campaign may fail.").

57. Risse \& Sikkink, supra note 51, at 26 (citing Alison Brysk, From Above and Below: Social Movements, the International System, and Human Rights in Argentina, 26 Comp. Pol. Stud. 259, 261 (1993)).

58. See Lutz \& Sikkink, International Human Rights Law, supra note 31, at 655 ("We suggest that norms cascades are collections of norm-affirming events. These events are discursive events-that is, they are verbal or written statements asserting the norm."). The concept of norm cascades is borrowed from a literature that focuses on domestic norms. See, e.g., Cass R. Sunstein, Free Markets and Social Justice 34-38 (1997) ("Norm cascades occur when societies are presented with rapid shifts toward new norms.").

International legal process scholars offer similar explanations for human rights changes, focusing on "the process whereby an international law rule is interpreted through the interaction of transnational actors in a variety of law-declaring fora, then internalized into a nation's domestic legal system." Harold Hongju Koh, Bringing International Law Home, 35 Hous. L. Rev. 623, 626 (1998); see also Harold Hongju Koh, Why Do Nations Obey International Law?, 106 Yale L.J. 2599, 2645-56 (1997) (book review) [hereinafter Koh, Why Do Nations Obey?] (identifying three phases in process by which nations comply with international norms: "interaction" with transnational actors, "interpretation" of international norm, and "internalization" of norm into domestic legal systems); Janet Koven Levit, The Constitutionalization of Human Rights in Argentina: Problem or Promise?, 37 Colum. J. Transnat'l L. 281, 285-87 (1999) (applying international legal process model to human rights issues in Argentina). 
point, ${ }^{59}$ states find it increasingly difficult to dispute the validity of international rules or engage in rights violations. ${ }^{60}$

What roles do treaty ratification and treaty compliance play in the ideational analysis? The ideationalists' spiral model understandably takes a long view of human rights change to include the practices of the most repressive governments that are the world's worst rights violators. Accordingly, treaty ratification generally does not occur until the spiral's fourth and penultimate stage, after a state has acknowledged the validity of human rights norms and international monitoring mechanisms and is engaging advocacy networks over compliance issues. ${ }^{61}$

The empirical evidence gathered by ideationalists suggests that although a few states may ratify international agreements as a tactical concession to opponents, most states are aware that treaty ratification has consequences. Thus, they will not accept international standards unless they are "prepared to live up to these standards domestically." 62 Although rights violations may occur during this period, states no longer question the validity of international norms but instead seek to justify or explain their conduct. Habitual rule-consistent behavior only occurs in the model's fifth and final stage, as human rights norms become fully institutionalized in domestic legal structures. As compliance improves, advocacy networks begin to demobilize. ${ }^{63}$

The spiral model does not, however, presume that human rights changes are either unidirectional or uniform across states. 1n the model's early stages, states can increase repression of domestic groups and cut off their contacts with transnational allies to stall advances in rights protection. Arresting change later in the process is far more difficult, however. Once a fully mobilized domestic opposition with transnational links has formed, "there is not much . . oppressive rulers can do to fight off the pressure and to continue the violation of human rights." 64 In addition, not all states respond identically to international pressures. In a point that overlaps with liberal theory, ideational theorists claim that " $[t]$ o the degree that a nation values its membership in an emerging com-

59. See Martha Finnemore \& Kathryn Sikkink, International Norm Dynamics and Political Change, 52 lnt'l Org. 887, 896, 901 (1998) ("After norm entrepreneurs [agents with strongly held notions of appropriate behavior within a relevant community of actors] have persuaded a critical mass of states to become norm leaders and adopt new norms, we can say the norm reaches a threshold or tipping point.").

60. Risse \& Sikkink, supra note 5I, at 21-22; Finnemore \& Sikkink, supra note 59, at 904-05; see also Lutz \& Sikkink, International Human Rights Law, supra note 31, at 638 (explicating the phenomenon of human rights "norm cascades" in Latin America in the I980s)

61. Risse \& Sikkink, supra note 5I, at 29-30.

62. Thomas Risse \& Stephen C. Ropp, International Human Rights Norms and Domestic Change: Conclusions, in The Power of Human Rights, supra note 51, at 234, 250. But see Hathaway, supra note 8 , at 1999 (reporting results of statistical study concluding that noncompliance by states ratifying human rights treaties is common).

63. Risse \& Sikkink, supra note 51, at 31-33.

64. Id. at 35 . 
munity of liberal states, it will be more vulnerable to pressures than a state that does not value such membership." 65

In sum, ideationalists conclude that treaties do matter, and that their ratification is a necessary, although not a sufficient, condition for consistent observance of human rights standards. ${ }^{66}$ Given the complexity of the spiral model and the divergent pathways to compliance that it generates, more studies and empirical data are needed to refine ideational hypotheses over when and why treaty compliance occurs. ${ }^{67}$ These hypotheses are revisited in Part IV to assess the predictive power of ideational theory in light of the Caribbean backlash.

2. Liberal Theory: The Role of Incorporation and Supranational Judicial Review in Securing Treaty Compliance. - Scholars of liberal theory (working in human rights and other international fields) have focused on a different explanation for treaty compliance, derived from an analysis of the strategies states adopt to "implement" their international commitments. ${ }^{68}$ These implementation strategies map across two distinct but interrelated variables: (1) the incorporation of international commitments into national law, and (2) the use of supranational judicial review to interpret those commitments and assess alleged violations. ${ }^{69}$ As explained below, the presence of high values for each of these variables (that is, deeper

65. Id. at 24.

66. See, e.g., Risse \& Ropp, supra note 62, at 276-77 (asserting that signing and ratifying international agreements is the first step toward institutionalizing human rights norms into domestic law, but that such "prescriptive status is inadequate in and of itself").

67. Other international relations scholars have questioned whether the norms-driven analysis of ideational and transnational legal process theorists adequately explains the evolution of a consensus favoring human rights protection. See Kahler, supra note 53, at 678 ("Although normative analysis identifies actors and processes, explanation too often appears to be post hoc."); Moravcsik, Origins, supra note 34, at 225 (questioning explanatory power of ideational theory); see also Raustiala \& Slaughter, supra note 9, at 544 (noting that transnational legal process model conflates independent and dependent variables).

68. Raustiala, supra note 6 , at 392 ("Implementation refers to the process of putting international commitments into practice: the passage of domestic legislation, promulgation of regulations, creation of institutions (both domestic and international), and enforcement of rules.").

69. See Raustiala \& Slaughter, supra note 9 , at 541-48 (describing these variables and others relating to compliance, including "problem structure; solution structure; solution process; norms; domestic linkages; and international structure"). The supranational judicial review variable is a particularized version of the "delegation" variable identified in the legalization literature, according to which the legalized attributes of an international regime are measured by whether states delegate interpretation, monitoring, and dispute settlement functions to a neutral third party. See supra Part I.A. Outside of the human rights context, however, such third parties often do not have (and from the perspective of optimal regime design, often should not have) any adjudicatory powers. See Raustiala, supra note 6, at 423-27 (discussing the success of nonbinding enforcement mechanisms in recent international environmental agreements). By contrast, the human rights landscape is rich in supranational courts, tribunals, and quasi-judicial review bodies. See Helfer, supra note 1, at 298-301 (describing the detailed procedures of three U.N. treaty bodies that monitor compliance with specific human rights treaties). 
incorporation or a more powerful supranational tribunal) independently favors treaty compliance. Moreover, the two variables often interact synergistically in ways that enhance compliance opportunities.

Consider first the incorporation of international rules into domestic legal systems-what liberal and other scholars have variously described as "embeddedness," 70 or "internalization."71 In its legal incarnation, incorporation occurs when national judiciaries give a treaty direct effect (in American parlance, treat it as self-executing) or when national legislatures transpose a treaty into a constitution or statute. This penetration into the domestic sphere allows private parties to invoke the weight of national judicial authority to press for compliance with international rules. ${ }^{72}$ Thus, holding other variables constant, liberal theory predicts that higher degrees of legal incorporation should be associated with higher levels of treaty compliance. ${ }^{73}$

Distinctly, states can create independent international institutions to review states' compliance with treaty commitments. Although human rights law contains the full spectrum of these bodies, liberal scholars devote particular attention to those courts and court-like institutions (often referred to as "supranational" or "transnational" tribunals) to which aggrieved individuals and groups have direct access. ${ }^{74}$ As compared to judicial institutions before which only states may appear, such tribunals are more likely to receive a large number of cases challenging the treaty-compatibility of national government practices. ${ }^{75}$ Whether this surge of individually initiated cases in itself enhances treaty compliance is unclear; at a minimum, it generates opportunities to impose domestic political pressure on governments to adhere to international rulings. ${ }^{76}$

70. Keohane et al., supra note 47 , at 458 .

71. Risse \& Sikkink, supra note 51 , at 5.

72. A prominent example of this in the human rights context is the incorporation of the European Convention on Human Rights into the domestic laws of the Convention's contracting parties. See generally Andrew Z. Drzemczewski, European Human Rights Convention in Domestic Law: A Comparative Study 260-303 (1983) (discussing signatories to the European Convention that have incorporated the treaty into domestic law, thereby allowing individuals to invoke the treaty or the ECHR's judgments in national judicial proceedings).

73. Keohane et al., supra note 47 , at 478 ("Other things being equal, the more firmly embedded an international commitment is in domestic law, the more likely is compliance with judgments to enforce it.").

74. See Helfer \& Slaughter, supra note 7, at 289 ; Keohane et al., supra note 47 , at 458 .

75. Keohane et al., supra note 47 , at 474.

76. Alter, supra note 16, at 507-08; see also Kahler, supra note 53, at 675 (describing how, under regional human rights conventions, legalization and transnational dispute settlement "strengthened transnational networks that mobilized in support of domestic compliance constituencies"); Keohane et al., supra note 47 , at 478 ("Individuals and groups can zero in on international court decisions as focal points around which to mobilize, creating a further intersection between transnational litigation and democratic politics."). 
Thus, holding other variables constant, ${ }^{77}$ the existence of supranational adjudication in a treaty regime should be associated with higher levels of treaty compliance.

Domestic incorporation of international commitments and supranational judicial review of those commitments each independently enhances prospects for treaty compliance. But neither alone is a sufficient guarantee of compliance. To the contrary, because these two attributes are endogenous choices available to states when designing treaty regimes, states may choose them only when they are predisposed to comply with international commitments. ${ }^{78}$ Empirical evidence reviewed by liberal scholars, however, suggests that when both attributes coexist, compliance levels rise significantly. Most notably, the Treaty of Rome ${ }^{79}$ and the European Convention ${ }^{80}$ - treaties that require significant modifications to national laws-are characterized by deep incorporation, powerful supranational tribunals, and membership limited to liberal democracies. Both agreements exhibit high rates of compliance rivaling those found in domestic legal systems. ${ }^{81}$

How did incorporation and supranational judicial review function together to enhance treaty compliance in Europe? Studies of the Treaty of Rome and the European Convention, and of their supranational tribunals, the European Court of Justice (ECJ) and the European Court of Human Rights (ECHR), focus on two different time periods. ${ }^{82}$ During an initial period after the treaties came into force, the two courts forged links with domestic state and nonstate actors interested in seeking compliance with their rulings. In particular, they sought to align the interests of private litigants (seeking to enforce treaty provisions that benefited them) with those of domestic court judges (seeking to augment their power of judicial review or, in the case of the European Community (EC), to bypass the authority of higher national courts by referring cases

77. Such variables include the "independence" of the international tribunal and the liberal or nonliberal regime type of states parties to the treaty creating it. See Keohane et al., supra note 47 , at 459-62, 478-79.

78. Cf. Raustiala, supra note 6 , at 392 (discussing treaty regimes in which compliance levels are high because states have adopted international standards that precisely match existing domestic practices).

79. Treaty Establishing the European Economic Community, Mar. 25, 1957, 298 U.N.T.S. 11 ,

80. Convention for the Protection of Human Rights and Fundamental Freedoms, Nov. 4, 1950, 213 U.N.T.S. 221 [hereinafter European Convention].

81. See supra note 17 and accompanying text.

82. See Alec Stone Sweet \& Thomas L. Brunell, Constructing a Supranational Constitution: Dispute Resolution and Governance in the European Community, $92 \mathrm{Am}$. Pol. Sci. Rev. 63, 65 (1998); see also Anne-Marie Burley \& Walter Mattli, Europe Before the Court: A Political Theory of Legal Integration, 47 Int'l Org. 41, 41 (1993) (describing different mechanisms by which ECJ promoted integration of European Community); Helfer \& Slaughter, supra note 7, at 290-96 (recounting processes used by ECJ and ECHR to enhance their authority in relation to European governments). 
directly to the ECJ). ${ }^{83}$ Once such links were established, the tribunals adopted legal doctrines that enhanced their own authority and pressed for deeper incorporation, often in ways unanticipated by the treaties' drafters. In short, supranational jurists in Europe consciously sought to augment the two treaty regimes in ways that favored compliance.

\section{Human Rights Treaty Evolution and the Overlegalization of Human Rights}

As this brief overview of the two European courts illustrates, state compliance with legalized international commitments is often intimately related to the question of whether and how those commitments evolve over time.

Initially, the levels of obligation, precision, and delegation contained in a treaty, as well as the degrees (if any) of incorporation and supranational judicial review, are fixed by governments themselves as conscious acts of regime design. ${ }^{84}$ Consider the choices governments face when

83. In the case of the ECJ, litigants filed cases in national courts, which in turn referred the cases to the ECJ for rulings on the treaty compatibility of national laws and policies. Enforcement of these rulings was left not to the vagaries of domestic politics, but instead entrusted to the same national jurists who had referred the cases, thereby enabling their enforcement as part of the domestic legal order. See Alter, supra note 16, at 492 (explaining how the ECJ encouraged national courts to use preliminary reference procedure and thereby "turned national courts into enforcers of European law in the national sphere"). In the case of both the ECJ and the ECHR, the court "craft[ed] opinions that encourage[d] national judges to view development of supranational law as a common project, while reassuring them that their own jurisdiction [would] be respected." Abbott, supra note 3, at 378; see also Helfer \& Slaughter, supra note 7, at 297-98 (noting that the ECHR and ECJ "achieved substantial compliance with [their] judgments by forging relationships with domestic government institutions, both directly and indirectly through relationships with private parties").

84. See Raustiala \& Slaughter, supra note 9 , at 550 (reviewing literature on design of international regimes); see also Barbara Koremenos et al., The Rational Design of International Institutions, 55 lnt'l Org. 761, 762 (2001) (arguing that "states use international institutions to further their own goals, and they design institutions accordingly" (emphasis omitted)).

Althougb the states that negotiate a human rights treaty have the most influence over setting its legalization and incorporation levels, individual ratifying states have some leeway to adjust those levels to suit their domestic particularities through the use of reservations. See Inter-American Commission on Human Rights, Signatures and Current Status of Ratifications: American Convention on Human Rights, available at http://www.cidh.oas. org/Basicos/basic4.htm (last visited Aug. 12, 2002) (on file with the Columbia Law Revierv) [hereinafter American Convention Ratification Chart] (listing reservations filed by states at time of ratification); United Nations, 1 Multilateral Treaties Deposited with the SecretaryGeneral: Status as of 31 December 2001, at 181, 182-225, U.N. Doc. ST/LEG/SER.E/20, U.N. Sales No. E. 02.V.4 (2002); an updated version is available at http://untreaty.un.org/ ENGLISH/bible/englishinternetbible/partI/chapterlV/treaty5.asp (on file with the Columbia Law Review) [hereinafter ICCPR Ratification Chart] (same). A reservation alters the receptivity of the reserving state's domestic legal system to international rules and institutions. A prominent (and controversial) example is the package of reservations, understandings, and declarations adopted by the United States when ratifying multilateral human rights treaties. Compare Kenneth Roth, The Charade of US Ratification of International Human Rights Treaties, 1 Chi. J. Int'l L. 347,347 (2000) (lamenting that the 
negotiating human rights agreements. Often the trade off is between a treaty's hard and soft law elements. ${ }^{85}$ States may tolerate rather high levels of precision, but only if levels of obligation and delegation are more attenuated. This occurred in the European Convention, where governments approved a mandatory set of detailed substantive rules, but made the right of individual petition and recognition of the ECHR's jurisdiction wholly optional. ${ }^{86}$ Other human rights regimes reflect similar efforts to mute full legalization, for example by making the right of individual petition mandatory but making the resulting decisions recommendatory rather than binding. ${ }^{87}$

Why are governments so concerned about a human rights treaty's legalization variables? The answer lies in the domestic political costs of protecting individual liberties. Altering domestic policies to conform to international human rights standards is not costless. ${ }^{88}$ Such alterations impose external constraints on a government's ability to respond to legitimate social problems by regulating the behavior of individuals within its

United States, out of fear and arrogance, ratifies human rights treaties in such a way as to preclude any domestic effect), with Jack Goldsmith, Should International Human Rights Law Trump US Domestic Law?, I Chi. J. Int'l L. 327, 329 (2000) (defending the United States practice of limiting domestic effect of international human rights treaties because the domestic costs outweigh the domestic and international benefits). The validity of a reservation depends upon its compatibility with the object and purpose of the treaty. For a detailed discussion, see General Comment 24 (52) on lssues Relating to Reservations Made Upon Ratification or Accession to the Covenant or the Optional Protocols Thereto, or in Relation to Declarations Under Article 41 of the Covenant, U.N. GAOR, Hum. Rts. Comm., 50th Sess., Supp. No. 40, at I19, U.N. Doc. A/50/40 (1996), available at http:// www.unhchr.ch/tbs/doc.nsf/symbol/69c55b086f72957ec 12563ed004ecf7a?open

document (on file with the Columbia Law Review) (identifying "the principles of international law that apply to the making of reservations and by reference to which their acceptability is to be tested and their purport to be interpreted").

85. See Abbott \& Snidal, supra note 36 , at 424-50 (discussing the advantages and disadvantages of hard and soft law and why states choose one form of international cooperation over the other); Raustiala, supra note 6, at 423-27 (exploring benefits of nonbinding instruments and the possibility that they may be more effective than legally binding treaties). See generally Commitment and Compliance: The Role of Non-Binding Norms in the International Legal System (Dina Shelton ed., 2000) (reviewing different subject areas of international law in which states have created nonbinding norms and standards).

86. Moravcsik, Origins, supra note 34 , at 218.

87. Compare American Convention, supra note 26, art. 44, S. Exec. Doc. F, 95-2, at 53, 1144 U.N.T.S. at 155 (requiring states parties to grant individuals right of access to Inter-American Commission), with Caballero Delgado \& Santana Case, Inter-Am. Ct. H.R. 135, 154, OAS/Ser.L/V/I11.33, doc. 4 (1995) (confirming that a "recommendation" issued by the Inter-American Commission "does not have the character of an obligatory judicial decision"). Legalization under the ICCPR is even more attenuated, since states need not permit individuals to file complaints with the U.N. Human Rights Committee, and even if they do, the decisions of the Committee are not binding. See Helfer \& Slaughter, supra note 7 , at $341-43,351$.

88. See Hathaway, supra note 8 , at 1951 ("Countries that are parties [to human rights treaties] may . . . be required to make potentially costly system-wide changes in order to bring themselves into compliance."). 
borders or by allocating resources to other areas of social policy-both traditional aspects of state sovereignty. States have differential preferences for committing themselves to these external constraints, which may vary based on their regime type, level of socioeconomic development, responsiveness to domestic civil society, or desire to impose human rights obligations on other states. ${ }^{89}$ As a result of these differing preferences, states intentionally design international agreements with varying levels of legalization to allow themselves a measure of flexibility to achieve societal objectives that rival the protection of individual rights.

This cost-benefit view of legalization may seem a more apt tool for analyzing treaties regulating international trade or international environmental law than agreements that protect individual liberties. But such balancing can also be a useful way to analyze human rights accords, given the pragmatic reality of the international system in which states determine a treaty's structure and retain the power to control if and when they will be bound by it through the acts of ratification and denunciation. ${ }^{90}$ Moreover, the widespread prevalence of derogation and "clawback" clauses in human rights agreements ${ }^{91}$ supports the argument that states

89. From a realist perspective, a powerful state might use weakly legalized treaties as part of a long-term strategy to pressure other states toward greater adherence to human rights standards. Since compelling other states to alter their human rights policies is not costless even for a hegemon, it might be rational for the powerful state to press for the ratification of a human rights treaty with low or moderate levels of legalization. Later, the state might add additional modes of financial or political pressure or seek to augment the treaty's legalization levels.

From an ideational perspective, a state might attempt to mollify domestic interest groups demanding human rights protections by negotiating and ratifying a human rights treaty with relatively weak legalization levels. According to the ideationalists' spiral model, however, ratification has consequences. It causes domestic and international advocacy groups to put increasing pressure on governments to improve their human rights performance.

From a liberal perspective, a partially legalized treaty might be the result of bargaining between newly democratic states (who seek high levels of obligation, precision, and delegation to lock in the requisites of democratic rule) and well-established democracies (who favor weaker human rights regimes or optional enforcement mechanisms to protect their sovereignty). See Moravcsik, Origins, supra note 34, at 228-29.

90. States may, of course, choose to make treaty ratification a one-way ratchet by precluding the possibility of exit. See Elizabeth Evatt, Democratic People's Republic of Korea and the ICCPR: Denunciation as an Exercise of the Right of Self-defence?, 5 Aust. J. Hum. Rts. 215, 219-20 (1998) (discussing Human Rights Committee's decision, in response to North Korea's attempt to denounce the ICCPR, that drafters intended to preclude states parties from denouncing the treaty).

91. Compare, e.g., American Convention, supra note 26, art. 27, S. Exec. Doc. F, 95-2, at 49,1144 U.N.T.S. at 152 (identifying limited emergency situations in which states may derogate from treaty obligations but listing rights from which no derogation is permitted), with European Convention, supra note 26, art. 10(2) (listing "formalities, conditions, restrictions or penalties" states may impose on the right to freedom of expression where "prescribed by law" and "necessarily in a democratic society" in the interests of, inter alia, "national security, territorial integrity or public safety, for the prevention of disorder or crime, for the protection of health or morals"). 
consciously draft treaties that-with a few notable exceptions-are only partially legalized to strike a balance between the protection of individual liberties and other important societal objectives. ${ }^{92}$

A state's attempt to fix the attributes of a treaty's structure during the negotiation stage does not, however, guarantee that those attributes will remain fixed once the treaty enters into force ${ }^{93}$ Where a treaty's obligation, precision, or delegation levels increase over time, government discretion to achieve countervailing societal objectives in tension with human rights diminishes. For example, an agreement's substantive standards or its review procedures can progress from weak norms and procedures that only modestly constrain government conduct to more obligatory legal rules or review mechanisms that compel governments to act or refrain from acting. Indeed, this transformation can occur between any two points on a continuum that stretches from entirely nonbinding norms and review mechanisms at one end of the spectrum to entirely binding rules and review procedures at the other, with numerous intermediate points. "Overlegalization" exists where a treaty's augmented legalization levels require more extensive changes to national laws and practices than was the case when the state first ratified the treaty, generating domestic opposition to compliance or pressure to revise or exit from the treaty. ${ }^{94}$

This definition of overlegalization can be disaggregated into two distinct types, each of which makes different assumptions about the relationship between a state's desire and ability to comply with its human rights commitments and the compliance expectations reflected in the treaty. In addition, each type of overlegalization has different normative consequences that can be used to evaluate claims that a treaty regime has become overlegalized.

1. Overlegalization that Changes Initial Treaty Bargains. - In the first type of overlegalization, the obligation, precision, and delegation levels of a human rights treaty-in the form that it is ratified-optimally balance the ratifying state's desire to protect individual liberties against its desire to achieve other governmental objectives in tension with that protection. Overlegalization occurs when the treaty's legalization levels rise over time, constraining a state's ability to achieve this balance. This might occur, for example, where a supranational tribunal expands a treaty's

92. Such balancing is not permitted, of course, where states draft a treaty right in absolute terms. See, e.g., European Convention, supra note 80, art. 3 ("No one shall be subjected to torture or to inhuman or degrading treatment or punishment."); id. art. 4(1) ("No one shall be held in slavery or servitude."). Where states choose such language, they conmit themselves to the proposition that no competing societal objective, however compelling, can justify the violation of that right.

93. For a discussion of what causes human rights treaties to evolve toward higher levels of legalization, see infra Part I.E.

94. The consequences of overlegalization may include an increase in noncompliance rates, proposals to amend a treaty to more accurately reflect state preferences, and denunciations of one or more instruments within a treaty regime. 
mandatory substantive reach (thereby increasing obligation), narrowly interprets ambiguous derogation or "clawback" clauses (thereby increasing precision), or concludes that states are required to implement its nonbinding recommendations (thereby increasing delegation). ${ }^{95}$ Given the assumption of perfect correspondence between domestic preferences and the state's international commitments at the time of ratification, domestic opposition to compliance or pressure to exit from the treaty should increase if the state adheres to the treaty in its overlegalized form.

Challenges by a state objecting to the existence of this first type of overlegalization have some intuitive appeal. After all, the increase in legalization has "changed the rules of the game" for the ratifying state by adding new obligations, specifying existing obligations with greater particularity, or strengthening mechanisms for review and enforcement. These were not the commitments that the state agreed to undertake when it first joined the treaty regime.

This does not mean, of course, that optimal levels of legalization in a treaty cannot evolve over time to create more deeply legalized human rights commitments. Such a result might occur, for example, where states and their citizens develop preferences for stronger human rights protection in response to pressure from domestic and transnational advocacy groups (an ideational explanation) or from powerful states (a realist account), or where supranational tribunals successfully lock in the requisites of democracy (as liberal theory asserts) ${ }^{96}$ But this type of overlegalization does illustrate how evolving treaty regimes can become too constraining, forcing governments to choose among noncompliance, revising the treaty, or denouncing it.

2. Overlegalization that Improves Enforcement Opportunities. - A second type of overlegalization is also plausible. This type relaxes the assumption of a perfect correlation between domestic preferences for human rights

95. See, e.g., Grigoriades v. Greece, 57 Eur. Ct. H.R. 2575, 2589 (1997) (holding that the ECHR's review of limitations on right to freedom of expression is not "limited to ascertaining whether the respondent State exercised its discretion reasonably, carefully and in good faith," but rather that the court must "look at the interference complained of in the light of the case as a whole and determine whether it was "proportionate to the legitimate aim pursued' and whether the reasons adduced by the national authorities to justify it are 'relevant and sufficient'"); Marckx v. Belgium, 31 Eur. Ct. H.R. (ser. A) at 19 (1979) (explaining that ECHR interprets the European Convention "in light of presentday conditions" rather than adhering to human rights standards endorsed by the Convention's drafters); Bradshaw v. Barbados, Communication No. 489/1992, U.N. GAOR, Hum. Rts. Comm., 49th Sess., Supp. No. 40 vol. 2, at 305, 309, U.N. Doc. A/49/40 (1994) ("It is an obligation for the State party to adopt appropriate measures to give legal effect to the [nonbinding] views of the Committee as to the interpretation and application of the [1CCPR] in particular cases arising under the Optional Protocol.").

96. The striking success of the ECHR in expanding the obligations of the European Convention and its own review powers without creating diminished compliance with its judgments illustrates this possibility. See Helfer \& Slaughter, supra note 7, at 311-12 (explaining ways in which ECHR augmented its authority and expanded reach of the European Convention). 
protection within a state and the initial legalization levels in a human rights treaty. Instead, it assumes (perhaps more realistically) that such treaties are too onerous even at their inception to be fully adhered to without incurring significant costs or generating significant domestic opposition. Many states are unwilling or unable to incur these costs or to expose themselves to such opposition. Why, then, would they choose to ratify treaties containing commitments they are unlikely to meet?

Although ratification may signal a genuine desire to strive for compliance, ${ }^{97}$ it may also reflect the political benefits states gain (for example, from their citizens or from powerful states with a human rights agenda) from the expressive act of ratification. In this view, ratification functions "as a pleasing statement not necessarily intended to have any real effect on outcomes. It declares to the world that the principles outlined in the treaty are consistent with the ratifying government's commitment to human rights." 98 But states also know that their failure to live up to this commitment may not be detected. Outside of Europe, treaty review procedures are generally weak and only limited opportunities exist to impose direct or indirect sanctions for noncompliance. ${ }^{99}$ Because of this disjunction between a treaty's formal requirements and the practical opportunities for its enforcement, states can provide domestic levels of human rights protection that are lower than a treaty in fact requires. Under this set of assumptions, overlegalization occurs where opportunities to detect, expose, or remedy noncompliance increase over time, forcing states closer to the commitments formally enshrined in a treaty's text. ${ }^{100}$

Challenges to this second variant of overlegalization at first appear far from compelling. It hardly seems justifiable for a state to contest efforts to compel adherence to obligations that it willingly assumed. But if many states in fact fail to comply with the human rights treaties they ratify, as a recent comprehensive quantitative study concludes, ${ }^{101}$ increases

97. According to one assessment, states intend to comply with their treaty commitments but are unable to do so, for example, because of unavoidable time lags associated with inplementation or because they lack technical or administrative capacity or adequate resources. See Abram Chayes \& Antonia Handler Chayes, The New Sovereignty: Compliance with International Regulatory Agreements 10 (1995) (describing "willful flouting" of treaties as infrequent). Proponents of this approach advocate "management" of compliance by nonconfrontational, nonbinding mechanisms that monitor behavior, build capacity, and resolve disputes informally, thereby persuading states to adhere to their treaty commitunents. See id. at 22-28.

98. Hathaway, supra note 8, at 2005-06 (internal citation omitted).

99. See id. at 1938, 2008 (noting that "the major engines of compliance that exist in other areas of international law are for the most part absent in the area of human rights," and describing human rights monitoring systems as "woefully inadequate").

100. Given its focus on enforcement, this type of overlegalization should be associated with increases in delegation, either to supranational tribunals or to domestic courts.

101. See Hathaway, supra note 8, at 1999 (concluding that noncompliance with human rights treaties is common and that ratification is often associated with worse human rights ratings than would otherwise be expected). But see Koh, Why Do Nations Obey?, 
in legalization could produce the same sorts of reactions by states that rely on weak enforcement mechanisms to obscure noncompliance as may be produced by overlegalization that changes initial treaty bargains. Increases in delegation that make it easier to detect noncompliance might thus be normatively unassailable, but still capable of producing a backlash in the form of treaty denunciations.

From a pragmatic perspective, these arguments raise critical questions of regime design. For example, should nonstate advocates for human rights or states with high compliance rates continue to accept treaties with strong substantive rules but weak enforcement mechanisms to maintain broad-based participation by states with poor human rights records? Or should they seek to "trap" noncomplying states in their formal commitments by encouraging supranational tribunals and domestic courts to undertake more stringent review of treaty obligations, even at the risk of exit by some states? ${ }^{102}$ The normative implications are even more challenging. In the area of international trade, scholars have argued that there is an optimal level of imperfection in treaties that gives states leeway to address the uncertainties of the international marketplace. ${ }^{103}$ According to these scholars, escape clauses and loopholes in a treaty's text ${ }^{104}$ and weak or opaque review procedures are essential to ensure that agreements bend rather than break when negative economic shocks make noncompliance efficient. ${ }^{105}$ Whether these concepts can be translated to the human rights context is uncertain given the deontological arguments that support such rights. But they, along with the prag-

supra note 58, at $2599 \& \mathrm{n} .2$ (arguing that empirical studies "seem[ ] largely to have confirmed" Professor Henkin's "hedged but optimistic" assertion that "'almost all nations observe almost all principles of international law and almost all of their obligations almost all of the time" " (citing Henkin, supra note 5, at 47)).

102. Cf. George W. Downs et al., Managing the Evolution of Multilateralism, 52 Int'1 Org. 397, 400-06 (1998) (discussing the relative merits of different types of multilateral structures relating to free trade and environmental protection, such as organizations with more or less inclusive memberships).

103. See George W. Downs \& David M. Rocke, Optimal lmperfection? Domestic Uncertainty and lnstitutions in International Relations 76-77 (1995).

104. See B. Peter Rosendorff \& Helen V. Milner, The Optimal Design of International Trade Institutions: Uncertainty and Escape, 55 lnt'l Org. 829, 830 (2001) (defining "escape clauses" of international agreements as "any provision[s] of an international agreement that allow[ ] a country to suspend the concessions it previously negotiated without violating or abrogating the terms of the agreement"). The derogation clauses in human rights treaties discussed above function as escape clauses in times of national emergency. See supra note 91.

105. See Downs \& Rocke, supra note 103, at 77; see also Catherine Powell, Dialogic Federalism: Constitutional Possibilities for Incorporation of Human Rights Law in the United States, 150 U. Pa. L. Rev. 245, 292 (2001) (stating that “[b]ecause international law is a low-viscosity system, noncompliance occurs "without irreparably tearing the fabric of the governing legal orders'" (quoting Daniel Halberstam, Comparative Federalism and the Issue of Commandeering, in The Federal Vision: Legitimacy and Levels of Governance in the United States and the European Union 213, 225 (Kalypso Nicolaidis \& Robert Howse eds., 2001))). 
matic issues discussed above, raise the unsettling possibility that the optimal level of compliance with a human rights treaty for a particular state might be less than perfect compliance, and that therefore increasing the treaty's legalization levels might be counterproductive.

\section{E. The Causes and Consequences of Overlegalization: A Preliminary Assessment}

The possibility that international human rights treaties can become overlegalized raises intriguing questions. First, what causes the agreements to evolve over time and become more heavily legalized? Second, which state and nonstate actors press for increased legalization? Finally, at what point does the move toward higher legalization levels result in overlegalization? Answers to these questions will depend upon variables such as the particular agreement at issue, its membership and subject matter, and the precise pathways by which legalization increases. This Section provides only a preliminary general assessment of these issues. A more detailed and contextualized analysis appears in Parts III and IV, which discuss the Commonwealth Caribbean backlash against human rights regimes and the ability of international relations theories to explain the backlash.

International relations scholars differ over what triggers human rights treaties to evolve from their origins. According to ideational and some liberal theorists, governments do not anticipate the domestic political consequences of treaty membership and as a result are vulnerable to pressures to expand the treaty. ${ }^{106}$ Other liberal scholars, by contrast, assert that governments are fully aware that their initial decision to ratify a human rights agreement will create political pressure for further diminutions of sovereignty and that they design treaties accordingly. ${ }^{107}$

As this analysis makes clear, a diverse set of actors may press for treaty evolution. Executive or legislative officials may see advantages to revising a treaty's legalization levels after it enters into force. In such a case, overlegalization is less likely to occur since states themselves control the pace and extent of change. Nonstate actors-both domestic and transnational advocacy networks-can also seek to augment legalized commitments to achieve their objectives, often by enlisting the support of national courts or supranational tribunals. National courts augment legalization by giving a treaty direct effect or by construing domestic law in harmony with it-acts that increase the treaty's obligatory character by making its rules binding domestically as well as internationally. ${ }^{108}$ Supra-

106. See, e.g., Kahler, supra note 53, at 681 (reviewing legalization studies supporting conclusion that sometimes "governments have not foreseen the consequences of links between their own domestic politics and legalized international institutions").

107. See, e.g., Moravcsik, Origins, supra note 34, at 243 (discussing formation of European Convention on Human Rights).

108. See Joel P. Trachtman, Bananas, Direct Effect and Compliance, 10 Eur. J. Int'l L. 655,659 (1999) (arguing that when courts give international agreements direct effect, the 
national jurists also pursue expansionist strategies, as the ECHR and ECJ illustrate. The greater independence of these tribunals, their access to private parties with the incentive to challenge treaty violations, and their links to national courts have allowed them to expand the substantive scope and legalization levels of the agreements they interpret "without triggering noncompliance, withdrawal, or reform by national governments." 109

Where governments do not control a treaty's evolution, just how far can treaty commitments expand before states begin to resist them? Early liberal studies argued that once supranational tribunals had established relationships with national courts and private parties, supranational review would generate a "one-way ratchet" toward increasing levels of legalization and incorporation into domestic law. ${ }^{110}$ Recent liberal scholarship has identified more complex interactions among supranational tribunals and state and nonstate actors which challenge this assumption. Contrary to prior findings, "[n] egative feedback loops may also emerge" in the relationships among these actors, diminishing the scope and importance of international commitments and lowering levels of treaty compliance. ${ }^{111}$ Ideational scholars make similar claims regarding points in the spiral model of human rights change at which governments can return to repressive practices. 112

Finally, for any pathway of treaty evolution, the pace of change must also be considered. The growth rate endorsed by a state's executive or legislative bodies may lag behind the rate of change that judicial and nonstate actors seek to impose. In Europe, for example, it took more than thirty years for all governments to ratify the European Convention's optional judicial review clauses, thus enabling a structural revision of the treaty to make such review mandatory. ${ }^{13}$ Evolutionary strategies adopted

agreements can be automatically implemented and thus are more heavily legalized than treaties not given such effect); see also Keohane et al., supra note 47, at 466-67 (arguing that control of governments is at its apex where "autonomous national courts can enforce international judgments against their own governments").

109. Id. at 479-80; see also Alter, supra note 16, at 492 (noting how ECJ acted to increase obligation, precision, and delegation of European Union (EU) treaties).

110. Burley \& Mattli, supra note 82, at 60 (discussing history of the ECJ).

111. Alter, supra note 16, at 512. As Karen Alter demonstrates in her study of the ECJ, the very success of the court in expanding the reach of European integration may have precipitated a backlash against it. Alter notes the limitations member states have placed on the ECJ's powers and the resistance some national courts have shown to implementing EU law. Id. at 512-15.

112. See Risse \& Sikkink, supra note 51, at 18.

113. See Keohane et al., supra note 47, at 485 (noting that creation of Protocol 11, making jurisdiction of ECHR compulsory and permitting individuals direct access to the court, occurred after three-decade period during which all European governments voluntarily recognized ECHR's jurisdiction and granted individuals access to European Commission on Human Rights); see also Moravcsik, Explaining, supra note 47, at 181 (noting that human rights commitments "develop slowly, even among stable and advanced democracies"). 
by national courts or supranational tribunals may proceed more rapidly, as the histories of the ECJ and the Human Rights Committee reveal. ${ }^{114}$

The disjunctions between these differing rates of change highlight potential fault lines of overlegalization within evolving treaty systems. They also suggest that judicial actors pressing for increased legalization must exercise caution to avoid "provok[ing] a backlash that contribute[s] to disintegration" of a treaty. ${ }^{115}$ In the case of the European Community, for example, such a backlash took the form of amendments to the EC treaties adopted by member states to "reverse or qualify" the effects of expansive ECJ rulings or to "constrain the ECJ's activism." 116 These governmental responses to overlegalization were largely incremental, however. Full-scale exit from the Community by a state dissatisfied with the ECJ's legalization efforts was not a viable option given the broad crosssection of issues contained in the EC treaties and the adverse effects of denunciation on domestic interest groups. As the next Part explains, however, no similar issue linkages deterred Commonwealth Caribbean states from denouncing their human rights obligations. As a result, when the region's highest court issued a highly unpopular decision that increased the treaties' legalization levels in the area of capital punishment, exiting the treaties became a viable political strategy for Caribbean governments.

\section{The Human Rights Backlash in the Commonwealth Caribbean}

This Part describes the human rights backlash in the Caribbean. It begins by identifying the common political and legal structures shared by Commonwealth Caribbean nations as well as divergences among the three states who denounced human rights treaties-Jamaica, Trinidad \& Tobago, and Guyana. It then turns to a roughly chronological narration of events beginning in the I980s and leading up to the denunciations of human rights treaties and petition procedures by these three states between 1997 and 2000. The narrative focuses in particular on a watershed decision of the Privy Council, Pratt $v$. Attomey-General for Jamaica, ${ }^{17}$ which generated a new set of interactions among supranational tribunals, national courts, private litigants, and transnational advocacy networks. The case, and the interactions it precipitated, illustrate one way in which a human rights agreement can become overlegalized. These events also provide a factual foundation for assessing how accurately the interna-

114. See Helfer \& Slaughter, supra note 7, at 290-93, 338-66 (identifying strategies used by ECJ and Human Rights Committee to augment the legalized qualities of the respective treaties subject to their review).

115. Alter, supra note 16, at 490; see also Moravcsik, Explaining, supra note 47, at 182 ("Strongly pressuring countries to accept binding jurisdiction and the individual right of petition before they are ready to accept it voluntarily is to invite open noncompliance ....").

116. Alter, supra note 16 , at 513 .

117. [1994] 2 A.C. 1 (P.C. 1993) (appeal taken from Jam.). 
tional relations theories described in Part I explain the Caribbean human rights backlash.

\section{A. Political and Legal Systems and Efforts to Protect Human Rights}

1. Domestic Regime Types. - Jamaica, Trinidad \& Tobago, Guyana, and the nine other independent nations that comprise this region are all former colonies of the United Kingdom and present members of the British Commonwealth. ${ }^{18}$ Upon achieving independence beginning in the early 1960 s, ${ }^{119}$ each nation retained key features of British law and politics, including Westminster-style parliaments ${ }^{120}$ and common law legal systems. ${ }^{121}$ Caribbean nations deviated from the British model, however, by adopting written constitutions that endorsed judicial review and a rule of constitutional supremacy over legislative and executive action. ${ }^{122}$

In terms of domestic regime type, all but one of the states in the Commonwealth Caribbean are liberal democracies. ${ }^{123}$ Their govern-

118. See The Commonwealth, Who We Are, at http://www.thecommonwealth.org/ dynamic/Country.asp (last visited Aug. 12, 2002) (on file with the Columbia Law Review) (listing members of the Commonwealth). The twelve nations are Antigua \& Barbuda, The Bahamas, Barbados, Belize, Dominica, Grenada, Guyana, Jamaica, St. Kitts \& Nevis, St. Lucia, St. Vincent \& the Grenadines, and Trinidad \& Tobago. Guyana and Belize, although not geographically part of the Caribbean, are generally included in the term "Commonwealth Caribbean" because of their historical and political links to Britain. See Rose-Marie Belle Antoine, Commonwealth Caribbean Law and Legal Systems 3 \& n.1 (1999) (noting that Guyana and Belize are geographically part of South and Central America, respectively, but arguing that the "Commonwealth Caribbean" is a political region created from the British colonial experience).

119. Jamaica and Trinidad \& Tobago became sovereign nations in 1962. Guyana followed in 1966. Laurel B. Francis, Caribbean Community States and State Succession, in Caribbean Perspectives on International Law and Organizations 84, 84 \& nn.3-4, 85, 87 n. 15 (B.G. Ramcharan \& L.B. Francis eds., 1989).

120. See Arend Lijphart, Democracies: Patterns of Majoritarian and Consensus Government in Twenty-One Countries 1-20 (1984) (discussing the Westminster model of democracy); Anthony Payne, Westminster Adapted: The Political Order of the Commonwealth Caribbean, in Democracy in the Caribbean: Political, Economic, and Social Perspectives 57, 60-72 (Jorge 1. Domínguez et al. eds., 1993) (evaluating Caribbean adaptation of Westminster model based on characteristics of "constitutionalism," "civilian supremacy," "bureaucratic and police neutrality," "competitive elections," and "pluralist representation").

121. Antoine, supra note 118, at 28-30. This is true even for Guyana, whicb retains only remnants of a Roman law system imposed by the Dutch. Id. at 51 .

122. Id. at 41, 83; Sir Fred Phillips, Freedom in the Caribbean: A Study in Constitutional Change 124 (1977). For the three nations under study, these constitutions were drafted by local state and nonstate actors, albeit with strong support from the British Colonial Office. 1d. at 79-80 (describing drafting of constitutions of Jamaica, Trinidad \& Tobago, and Guyana and characterizing them as "autochthonous" or "home-grown" instruments (citing K.C. Wheare, The Constitutional Structure of the Commonwealth 93-95 (1960))); A.W. Brian Simpson, Human Rights and the End of Empire: Britain and the Genesis of the European Convention 870-73 (2001) (discussing support of Colonial Office for inclusion of bills of rights clauses in domestic constitutions of former British colonies).

123. See supra note 45 (defining liberal democracies). 
ments are chosen by free and fair elections among competing political parties, their judiciaries are independent (if sometimes underfunded), ${ }^{124}$ and state actors protect basic civil and political liberties as well as property rights while upholding the rule of law. ${ }^{125}$ lndeed, the strength and resiliency of liberal democratic structures in the Commonwealth Caribbean are unique among developing nations and contrast sharply with the nearby nations of Central and South America, which have been governed by autocratic or unstable regimes until a democratizing trend took hold in the $1980 \mathrm{~s} .{ }^{126}$

Guyana is the only longstanding exception to these regional commonalities. ${ }^{127}$ After the country's last free election under British rule in 1964, Guyana was governed for more than twenty years by Forbes Burnham, an autocratic socialist leader who declared his ruling party para-

124. See Albert Fiadjoe, Caribbean Public Law 151-53 (1996) (noting constitutional guarantee of judicial independence and discussing increasing development of lower court independence); Telford Georges, The Scope and Limitations of State Machinery, in Human Rights and Development: Report of a Seminar on Human Rights and Their Promotion in the Caribbean 40, 47 (1nt'l Comm'n of Jurists \& The Org. of Commonwealth Caribbean Bar Ass'ns eds., 1977) (arguing that judiciary is "adequate[ly]" independent with exception of lifetime tenure provisions). But see Antoine, supra note 118, at 223-26 (arguing that although judicial independence is embedded in Commonwealth Caribbean constitutions, problems of limited qualified personnel and financial resources may undermine achievement of true autonomy).

125. See Freedom House, Democracy's Century: A Survey of Global Political Change in the 20th Century 1, 4, at http://www.freedomhouse.org/reports/century.pdf (last visited Aug. 12, 2002) (on file with the Columbia Law Review) (identifying Commonwealth Caribbean states in the year 2000 as "democracies" in which "leaders are elected in competitive multi-party and multi-candidate processes in which opposition parties have a legitimate chance of attaining power or participating in power"); see also Ivelaw L. Griffith \& Trevor Munroe, Drugs and Democratic Governance in the Caribbean, in Democracy and Human Rights in the Caribbean 74, 82 (Ivelaw L. Griffith \& Betty N. Sedoc-Dahlberg eds., 1997) ("Relative to other states, Caribbean states have over the last fifty years been exceptional in the consistency of fair and free elections, the observation of political rights and civil liberties, competitive party systems, and the rule of law."); Merle McCormack, A Non-Governmental Organisation Perspective on Human Rights Action in the Caribbean, in International Human Rights Law in the Commonwealth Caribbean 348, 348 (Angela D. Byre \& Beverley Y. Byfield eds., 1991) ("Commonwealth Caribbean countries have, by and large, retained a high level of Parliamentary democracy . . . .).

126. See Jorge 1. Donínguez, The Caribbean Question: Why Has Liberal Democracy (Surprisingly) Flourished?, in Democracy and the Caribbean, supra note 120, at 1, 2-3; cf. Lutz \& Sikkink, Justice Cascade, supra note 35, at 7 (noting "regional wave of redemocratization between 1978 and 1991" in Latin America).

127. Grenada is another limited exception to the region's strong liberal democratic history. The 1979 revolution in that country led to a four-year suspension of democratic political structures. See Clifford E. Griffin, Democracy and Political Economy in the Caribbean, in The Political Economy of Drugs in the Caribbean 113, 134 n.2 (Ivelaw L. Griffith ed., 2000); see also McCormack, supra note 125, at 350 (noting that the independence of the judiciary has been somewhat undermined in Grenada). Another minor exception is the nation of Antigua \& Barbuda, where there have been claims of electoral fraud and corruption since 1976 with respect to the Antigua Labor Party. See Griffin, supra, at 136 n.2. 
mount to the state, suppressed free elections, compromised the judiciary, and violated human rights. State socialism and one-party control began to erode after Burnham's death in 1985 and accelerated after free elections were held in 1992. ${ }^{128}$ Additional free elections and changes of government followed, but as of 2001 Guyana was still making a slow and unsteady transition to democratic rule. ${ }^{129}$

2. Domestic and International Protection of Human Rights. - Another point of regional commonality (again with only partial applicability to Guyana) is a moderately good record of protecting human rights in domestic legal systems. ${ }^{130}$ According to annual surveys by Freedom House, the Commonwealth Caribbean ranks well above the global average in the enjoyment of political rights and civil liberties. ${ }^{131}$ In addition, Commonwealth Caribbean constitutions contain detailed bills of rights closely modeled on the European Convention on Human Rights and the Universal Declaration on Human Rights. ${ }^{132}$ Promotion of human rights also

128. See lvelaw L. Griffith, Democracy and Human Rights in Guyana, in Democracy and Human Rights in the Caribbean, supra note 125, at 156, 158-59; W. Marvin Will, NGOs and 1GOs as Promoters of Liberal Democracy in the Caribbean: Cases from Nicaragua and Guyana, in Democracy and Human Rights in the Caribbean, supra note 125 , at $51,60-67$.

129. See Bureau of W. Hemisphere Affairs, U.S. Dep't of State, Background Note: Guyana (2001), available at http://www.state.gov/r/pa/ei/bgn/1984.htin (on file with the Columbia Law Review); U.S. Dep't of State, 1999 Country Reports on Human Rights Practices: Guyana (2000), available at http://www.state.gov/www/global/human_rights/ 1999_hrp_report/guyana.html (on file with the Columbia Law Review) [hereinafter 1999 Guyana Country Report].

130. See Val T. McComie, Legal Contribution of the Caribbean to the Inter-American System, in Caribbean Perspectives on International Law and Organizations, supra note 119 , at 432, 436 ("Respect for human rights is deeply rooted in the peoples of the Caribbean ... ."); McCormack, supra note 125, at 349-50 (noting that in English-speaking Caribbean "human rights problems have tended to be isolated and incidental rather than systemic").

For a discussion of problematic areas, including the criminal justice system, arbitrary detentions, and extra-judicial killings, see Florizelle O'Connor, The Jamaica Council for Human Rights: A Non-Governmental Organisation Case Study, in International Human Rights Law in the Commonwealth Caribbean, supra note 125, at 331, 333-45. A more detailed discussion of the human rights problems associated with Caribbean criminal justice systems appears infra Part Ill.C.

131. The Freedom House ratings range from 1 to 7 for political rights and for civil liberties, respectively, with 1 being the most rights-protective rating. In the period between 1973 and 2000, the ratings for Jamaica ranged from 1,2 to 2,3; for Trinidad \& Tobago from 1,1 to 2,3; and for Guyana from 2,2 to 5,5. Freedom House, Freedom in the World Country Ratings, 1972-1973 to 2000-2001, available at http://www.freedomhouse.org/ research/freeworld/FHSCORES.xls, (last visited Aug. 12, 2002) (on file with the Columbia Law Review). Guyana received the least rights-protective ratings (from 3,3 to 5,5) between 1974 and 1992 when democratic political structures were compromised and Freedom House designated the country as only "partly free." Guyana's rating has remained at 2,2 since 1993. Id.

132. Antoine, supra note 118 , at $157-58$. 
occurs through domestic NGOs and a system of ombudsmen who hear individual complaints of government abuses. ${ }^{133}$

The region's commitment to protecting human rights is not limited to the domestic sphere. Newly independent Commonwealth Caribbean governments also supported international institutions, ${ }^{134}$ including those relating to human rights. ${ }^{135}$ Jamaica and Guyana were early signatories to the ICCPR, in 1966 and 1968 respectively, and their ratifications followed nine years later in 1975 and $1977 .{ }^{136}$ Trinidad \& Tobago ratified the treaty in 1978 two years after revising its constitution. ${ }^{137}$ Jamaica ratified the Optional Protocol to the ICCPR (Optional Protocol) in 1975, as did Trinidad \& Tobago in 1980 , both well before the rapid wave of ratifications in the 1990s; Guyana followed suit in 1993 (after its first free postindependence elections in 1992). ${ }^{138}$ Adherence to Inter-American human rights rules and institutions was slower and more halting, largely because the Organization of American States (OAS) was created without Caribbean participation and because its basic instruments did "not reflect the reality and the interests of the Caribbean." 139 Jamaica did not ratify the American Convention until 1978, Trinidad until 1991 (at which time

133. Id. at 303-18; Rose D'Sa, National Institutions Concerned with the Promotion of Human Rights in Commonwealth Countries, in International Human Rights Law in the Commonwealth Caribbean, supra note 125, at 317, 324-27.

134. Prior to independence in the late $1950 \mathrm{~s}$, Caribbean governments formed a shortlived Federation of the West Indies. Phillips, supra note 122, at 21-77. Shortly thereafter, they formed a Caribbean Free Trade Association and later a Caribbean Common Market (CARICOM). G. Pope Atkins, Latin America and the Caribbean in the lnternational System 185-87 (1999).

135. This accords with Andrew Moravcsik's study of the European htıman rights system, which argues that newly emergent liberal democracies look to international human rights regimes "to 'lock in' and consolidate democratic institutions." Moravcsik, Origins, supra note 34 , at 220 .

136. 1CCPR Ratification Chart, supra note 84 , at 181 .

137. 1d. at 182. See also Phillips, supra note 122, at 191-97 (discussing constitutional reforms in Trinidad \& Tobago).

138. United Nations, 1 Multilateral Treaties Deposited With the Secretary-General: Status as of 31 December 2001, at 226-27, U.N. Doc. ST/LEG/SER.E/20, U.N. Sales No. E.02.V.4 (2002), available at http://untreaty.un.org/ENGL.1SH/bible/englishinternet bible/partl/chapterIV/treaty6.asp (on file with the Columbia Law Review) [hereinafter Optional Protocol Ratification Chart]; see Helfer \& Slaughter, supra note 7, at 344 n.314 (noting increase in Optional Protocol ratifications between 1991 and 1995).

139. McComie, supra note 130 , at 432 ; see also B.G. Ramcharan, Caribbean Community Perspectives on International Law and Organization, in Caribbean Perspectives on International Law and Organizations, supra note 119, at 1, 28 (noting that "Caribbean Community States have not been entirely at home in the OAS" and that "they have insisted on establishing and developing their own organizations"). Although Trinidad \& Tobago and Jamaica joined the OAS in 1967 and 1969, respectively, Guyana was precluded from joining under a rule barring membership to any nation in a territorial dispute with an existing OAS member. That rule was revised in the 1980 s, allowing Guyama to join in 1991. McComie, supra note 130, at 435-36; Organization of American States, Charter of the Organization of American States: General lnformation of the Treaty: A-41, available at http://www.oas.org/juridico/english/sigs/a-41.html (last visited Aug. 12, 2002) (on file with the Columbia Law Review) [hereinafter OAS Ratification Chart]. 
it also accepted the jurisdiction of the Inter-American Court of Human Rights ${ }^{140}$ ), and Guyana has yet to ratify the treaty. ${ }^{141}$

As a result of these ratifications, individuals who believed that the states had violated their rights under the ICCPR could file petitions with the U.N. Human Rights Committee, and those who asserted violations of the American Convention could file petitions with the Inter-American Commission on Human Rights. Each tribunal then reviewed the allegations in the petitions, sought responses from defending governments, and determined whether the countries had in fact violated their treaty obligations. The tribunals' findings were set out in nonbinding written decisions that often contained recommendations for the government concerned as to the measures necessary to remedy any violations. ${ }^{142}$

3. Domestic Legal Systems: The Role of the Privy Council. - Although Commonwealth Caribbean states gained political independence from the United Kingdom beginning in the 1960s, they did not sever their legal ties to that country. In addition to local trial and appellate courts, each state retained the London-based Judicial Committee of the Privy Council as its highest court of appeal. The Privy Council is comprised of a panel of British judges (all members of the House of Lords) which acted as the court of last resort for Britain's colonies, and which continues to serve that function for several Commonwealth states, including those in the Caribbean. ${ }^{143}$

Judicial review by the Privy Council is also an important component of human rights protection in the Commonwealth Caribbean. Beginning in the years immediately following independence, the court heard numerous appeals in which it interpreted the individual rights clauses in Caribbean constitutions. It began this task with circumspection, narrowly construing rights or relying on other constitutional provisions to limit their scope. ${ }^{144}$ By the 1980 s, however, the Privy Council's jurisprudence was divided between decisions that strictly interpreted individual rights

140. See American Convention, supra note 26, art. 62, S. Exec. Doc. F, 95-2, at 58, 1144 U.N.T.S. at 159 (setting out procedures for a state party to the American Convention to recognize the jurisdiction of the Inter-American Court of Human Rights).

141. American Convention Ratification Chart, supra note 84.

142. See Helfer, supra note 1, at 296-301 (describing procedures used by U.N. and regional human rights tribunals). In the case of Trinidad \& Tobago, the Commission could refer disputes to the Inter-American Court of Human Rights for a legally binding ruling. See American Convention, supra note 26, arts. 61-62, S. Exec. Doc. E, 95-2, at $57-58,1$ I 44 U.N.T.S. at 159 (setting forth procedures for referral of cases to InterAmerican Court involving states that have recognized the court's jurisdiction).

143. Office of the Privy Council, Jurisdiction of Judicial Committee (2000), available at http://www.privy-council.org.uk/output/Page32.asp (on file with the Columbia Law Review).

144. See Phillips, supra note 122, at 124-27, 143-44, 159-60 (reviewing decisions narrowly construing freedom of expression, property protections, the reach of the judicial power, guarantees against unreasonable searches, and rights of redress). 
clauses and others that endorsed a purposive and generous construction used by other common law courts and supranational tribunals. ${ }^{145}$

Throughout this period, the Privy Council's powers of judicial review remained controversial. As early as the 1970 s, government officials and academics targeted the court as a vestige of colonialism. ${ }^{146}$ Yet until the mid-1990s, Caribbean states (except Guyana ${ }^{147}$ ) made little effort to cast off the Privy Council as their highest court of review. ${ }^{148}$ Although advocates of self-determination may find this puzzling, cogent pragmatic and political arguments explain the region's reluctance to sever its links to the London-based jurists.

From a practical perspective, the instances of Privy Council review were rather infrequent in fact, even when they were available in theory. Filing appeals in London was costly for litigants, and over the years the court developed doctrines to limit the exercise of its appellate jurisdiction, particularly in criminal cases. ${ }^{149}$ These factors reduced the number of cases that the Privy Council decided on appeal from local Caribbean courts, and thus limited its ability to alter the Caribbean legal landscape. ${ }^{150}$

145. Compare Robinson v. The Queen, [1985] A.C. 956, 966-67 (P.C. 1985) (appeal taken from Jam.) (strictly construing constitutional provisions relating to right to legal representation), and Riley v. Attorney Gen. of Jam., [1983] 1 A.C. 719, 725-26 (P.C. 1982) (appeal taken from Jam.) (rejecting claim that extended stays on death row contravened constitutional prohibition on inhuman or degrading treatment), with Antoine, supra note 118, at 80-81 (mentioning Thornhill v. Attorney Gen., [1981] A.C. 61, 71 (P.C. 1979) (appeal taken from Trin. \& Tobago), and discussing Minister of Home Affairs v. Fisher, [1980] A.C. 319, 328 (P.C. 1979) (appeal taken from Berm.) (both adopting rightsprotective constructions of Caribbean constitutions)).

146. See Caribbean Task Force, Report of the Caribbean Task Force 102-03 (1974); see also Phillips, supra note 122, at 194, 625 (discussing criticism of appeals to the Privy Council and recommending creation of a regional appellate court to hear such appeals instead of Privy Council); cf. Sandra Fullerton Joireman, Inherited Legal Systems and Effective Rule of Law: Africa and the Colonial Legacy, 39 J. Mod. Afr. Stud. 571, 572 (2001) (labeling legal systems inherited by former European colonies in Africa as "the political detritus of colonisation").

147. Guyana severed its formal link to the Privy Council in 1970. See Antoine, supra note 118, at 89 n.6, 109 (citing Judicial Committee of Privy Council (Termination of Appeals) Act 1970, and discussing Guyanese case law after Guyana severed link to Privy Council).

148. See Hugh A. Rawlins, The Privy Council or a Caribbean Final Court of Appeal?, 6 Caribbean L. Rev. 235, 236 (1996) (stating that proposals to replace Privy Council with regional court of appeal have been treated "either as an intellectual debate for academic gratification or as a political or administrative exercise for the agenda of regional meetings").

149. See Antoine, supra note 118, at 230-34 (describing limitations on Privy Council jurisdiction, including in criminal cases, and concluding that "the Privy Council does not actually operate as a full appellate court"); Roget V. Bryan, Comment, Toward the Development of a Caribbean Jurisprudence: The Case for Establishing a Caribbean Court of Appeal, 7 J. Transnat'l L. \& Pol'y 181, 207 (1997) (noting expense of Privy Council appeals).

150. From 1985 to 1994, there were 214 appeals from Commonwealth Caribbean courts to the Privy Council. The court decided 163 appeals after a hearing while it 
For important questions of constitutional law, however, the political arguments for retaining appeals to the Privy Council were compelling. ${ }^{151}$ First, Privy Council review, paid for by Britain, was cheap for the Caribbean governments; second, the court was "perceived to be incorruptible and aloof from local pressures"; and finally, it was staffed by "able common law judges." ${ }^{152}$ The first rationale explains why Caribbean governments, overseeing new nations with many demands on the public fisc, supported the Privy Council. The second explains why the Caribbean public supported the court, and the third explains why Caribbean legal elites supported it. ${ }^{153}$ As explained in the next section, however, this constellation of governmental, public, and elite backing shifted significantly in the 1990s.

\section{B. Criminal Justice Systems and the Pratt Case}

1. The Rise of Death Rows in the Caribbean. - Beginning in the $1980 \mathrm{~s}$, crime rates in the Commonwealth Caribbean, and homicide rates in particular, rose sharply. Government officials blamed South American drug cartels (which used the Caribbean as a transshipment point for drugs bound for the United States) and the general decline in the region's economic growth. ${ }^{154}$ They responded by ending the unofficial moratoria on executions that had been in place since the 1970 s. $^{155}$

dismissed 68 appeals without a hearing. During the same period, litigants filed 292 petitions for special leave to appeal. Of these, the court granted only 87. M.A. De La Bastide, The Case for a Caribbean Court of Appeal, 5 Caribbean L. Rev. 401, 402-03 (1995).

151. Although much of the Privy Council's appellate jurisdiction is discretionary and requires leave to appeal, Caribbean constitutions grant litigants a right of appeal in cases alleging violations of constitutional rights or freedoms. Antoine, supra note 118, at 230-31.

152. Joseph O'Neill, The Ascent of Man, Granta, Winter 2000, at 187, 192; see also Jamaicans For Justice, Guide Sheet on the Privy Council and the Proposed Caribbean Court of Justice, at http://www.jamaicansforjustice.org/guide.htm (last visited Aug. 13, 2002) (on file with the Columbia Law Review) (noting that Privy Council was "free from any interference or pressure from politicians" in the Caribbean).

153. See Antoine, supra note 118, at 237-38 (discussing arguments in favor of retaining Privy Council jurisdiction and noting that incorruptibility argument appealed "to a people fearful of political interference in a society which they view as politically partisan and sometimes corrupt").

154. See lvelaw Loyd Griffith, Drugs and Security in the Caribbean: Sovereignty Under Siege 53-92 (1997); Griffith \& Munroe, supra note 125, at 78; O'Neill, supra note 152 , at 191 .

155. See O'Neill, supra note 152, at 191 (reporting Trinidad \& Tobago moratorium from 1979 to 1992); O'Connor, supra note 130, at 334-35 (Jamaican moratorium from 1976 to 1980); Guyana Rejects UN Protocol, South America Report, Jan. 1999, available at LEX1S, IAC (SM) Newsletter Database File (on file with the Columbia Law Review) (reporting that Guyana resumed executions in 1985). 
Contrary to a trend in other parts of the world, Commonwealth Caribbean nations had never abolished the death penalty. ${ }^{156}$ Some even made death a mandatory punishment for most, if not all, murder convictions. ${ }^{157}$ Capital punishment was also highly popular with citizens, and it became even more so in the wake of rising homicide rates. ${ }^{158}$ As a result of these combined pressures, an increasing number of criminal defendants received capital sentences and were placed on death row to await execution.

During the 1980 s and early 1990 s, complaints by these death row inmates began to reach the Privy Council, the Inter-American Commission, and the U.N. Human Rights Committee. One legal argument in particular began to appear with increasing frequency-the claim that a long period of detention on death row in itself was degrading or inhuman treatment or punishment proscribed by national constitutions and human rights treaties. ${ }^{159}$ This argument, which challenged what came to

156. See Amnesty Int'l, State Killing in the English Speaking Caribbean: A Legacy of Colonial Times 2 (2002), at http://web.amnesty.org/aidoc/aidoc_pdf.nsf/index/ AMR050032002ENGLISH/\$File/AMR0500302.pdf (on file with the Columbia Law Review) [hereinafter State Killing] ("Against the international trend away from the use of the death penalty, executions have increased in the English speaking Caribbean . . . in recent years." (footnote omitted)); see also Bernard Babb, Fresh Move Towards Caribbean Court of Appeal, Caribbean Wk., Oct. 26-Nov. 8, 1996, at 2 (noting that "[n] early all Caribbean territories have retained the death penalty in their constitutions").

157. See, e.g., Offences Against the Person (Amendment) Act, No. 14-1992, $115 \mathrm{Jam}$. Gazette (Supplement) 1, 1-4 (Nov. 27, 1992) (on file with the Columbia Law Review) (amending section 2(1) of the Offences Against the Person Act to define "capital murder" and prescribe a penalty of death for murder committed, inter alia, against certain persons by virtue of their employment, position or status, as well as for murder committed in the course of certain other crimes, including "robbery," "burglary or housebreaking," "arson," or "any sexual offence"); Offences Against the Person Act, 3 The Laws of Trinidad and Tobago, ch. 11:08, $\$ 4$ (1990) ("Every person convicted of murder shall suffer death."); United Nations, Human Rights Committee, Second Periodic Report of States Parties Due in 1987: Guyana, U.N. Doc. CCPR/C/GUY/99/2 (1999), available at http://www.unhchr. $\mathrm{ch} /$ tbs/doc.nsf/(Symbol)/CCPR.C.GUY.99.2.En?Opendocument (on file with the Columbia Law Review) (discussing Guyana criminal laws imposing sentence of death upon conviction of murder). But see infra note 226 (discussing a recent Privy Council decision holding mandatory death sentences unconstitutional).

158. See Griffin, supra note 127, at 241-42 tbl.13.6 (reporting 1994 survey in which ninety-six percent of Trinidadians expressed support for capital punishment); Annabel Pilling, A Hanging Offence, The Times (London), Sept. 21, 1999, at D5 (noting results of February 1999 poll revealing that eighty-seven percent of adult Jamaicans favored capital punishment); Peter Richards, Rights-Caribbean: Region Stands Firm on Death Penalty, Inter Press Serv., June 9, 1999, available at LEXIS, Inter Press Service File (on file with the Columbia Law Review) (reporting surveys showing support for death penalty at eighty-eight percent in Barbados and seventy percent in Trinidad \& Tobago).

159. See, e.g., Guy. Const. (Constitution of the Co-operative Republic of Guyana Act, 1980) pt. Il, tit. $1, \S 141$ (1) ("No person shall be subjected to . . . inhuman or degrading punishment or other treatment.”); Jam. Const. ch. Ill, § 17(1) (same); Trin. \& Tobago Const. ch. 1, $\$ 5(2)$ (b) ("Parliament may not . . impose or authorise the imposition of cruel and unusual treatment or punishment."); American Convention, supra note 26, art. 5(2), S. Exec. Doc. F, 95-2, at 42, 999 U.N.T.S. at 174 ("No one shall be subjected to . . 
be known as the "death row phenomenon," did not contest the legality of capital punishment per se but rather the protracted delays associated with waiting for execution while appealing a conviction and sentence. ${ }^{160}$

2. The Pratt Case. - The Privy Council considered the death row phenomenon argument in a November 1993 decision known as Pratt v. Attomey-General for Jamaica. ${ }^{161}$ The procedural history of Pratt is tortuous, with nearly a decade and a half of domestic appeals and international petitions. But the case merits detailed attention, both to illustrate the relationships between the Privy Council and the tribunals and to provide needed context for the legal and political responses to the Privy Council's decision reversing an earlier ruling and recognizing the death row phenomenon as a human rights violation. ${ }^{162}$

In January 1979, Earl Pratt and 1van Morgan were convicted of murder and sentenced to death. The Jamaican Court of Appeal affirmed their convictions and death sentences in December 1980, but did not issue reasons for its decision until September 1984. The defendants could have petitioned the Privy Council for leave to appeal at any time after the Court of Appeal affirmed their convictions, although their practical ability to do so was severely hampered without a written decision. 1nstead, the defendants filed international petitions with the lnter-American Commission and the Human Rights Committee. ${ }^{163}$

ln the first petition, brought to the 1nter-American Commission in June 1981, Pratt complained about various unspecified procedural errors during his capital trial and appeal. The Commission rejected this claim in October 1984, although it asked Jamaica to commute his death sentence on humanitarian grounds. ${ }^{164}$ Pratt then petitioned the Human Rights Committee in January 1986. His accomplice Morgan later filed a related petition and the two cases were joined. The petition alleged a number of violations of the 1CCPR, including a claim based on the death row phenomenon. ${ }^{165}$ In March 1986, while that petition was pending, the defendants sought leave to appeal to the Privy Council. In July of that year, the Privy Council refused to allow the appeal, although it expressed

cruel, inhuman or degrading treatment or punishment."); ICCPR, supra note 26, art. 7, S. Exec. Doc. E, 95-2, at 15, 999 U.N.T.S. at 175 (same).

160. See William A. Schabas, The Abolition of the Death Penalty in International Law 127-36, 236-38 (2d ed. 1997) (discussing application of death row phenomenon by different international human rights tribunals).

161. [19941 2 A.C. 1 (P.C. 1993) (appeal taken from Jam.).

162. See Riley v. Attorney Gen. of Jam., [1983] 1 A.C. 719, 724-27 (P.C. 1982) (appeal taken from Jam.) (concluding that delays in carrying out executions did not violate the "inhuman or degrading punishment or other treatment" clause in Section 17 of Jamaican Constitution).

163. Pratt, [1994] 2 A.C. at 9-22.

164. Pratt v. Jamaica, Case 9054, Inter-Am. C.H.R. 111, 113, OEA/ser.L/V/II.66, doc. 10 rev. 1 (1985).

165. Pratt v. Jamaica, Communication Nos. 210/1986 \& 225/1987, U.N. GAOR, Hum. Rts. Comm., 44th Sess., Supp. No. 40, at 222, U.N. Doc. A/44/40 (1989). 
concern over the Court of Appeal's nearly four-year delay in issuing a written decision. ${ }^{166}$

The defendants' petition to the Human Rights Committee was more successful. In July 1986, the Committee issued an interim decision requesting that Jamaica stay the executions of Pratt and Morgan pending a review of their allegations. Jamaica refused to comply, however, and in February 1987 it issued a warrant of execution for both men. Later that month the Governor General did issue a stay, apparently because the defendants' petitions had been scheduled for hearings in March 1987 by both the lnter-American Commission and the Human Rights Committee. ${ }^{167}$

The Commission was the first of the two tribunals to act. In July 1987, it informed Jamaica that the nearly four-year detention on death row while defendants awaited the Jamaican Court of Appeal's decision "was tantamount to cruel, inhuman and degrading treatment" in violation of the American Convention. ${ }^{168}$ In response to this decision, Jamaica once again vacillated on executing Pratt and Morgan, initially dellying and then granting a stay while the defendants' parallel petition to the Human Rights Committee was pending. In March 1988, more than two years after the defendants first filed that petition, the Committee declared their claims to be admissible. A further thirteen months elapsed before the Committee issued its decision on the merits in April 1989. The Committee found a violation of the ICCPR based on the Court of Appeal's delay in giving reasons for affirming the defendants' convictions, and it recommended that Jamaica commute their death sentences. ${ }^{169}$ But the Committee rejected the death row phenomenon claim, reasoning that "prolonged judicial proceedings do not per se constitute cruel, inhuman or degrading treatment even if they can be a source of mental strain for the convicted prisoners." 170

166. Pratt, [1994] 2 A.C. at 22-23.

167. Id. at 23-24. The Commission's authority to reexamine Pratt and Morgan's cases three years after it dismissed their petition is unclear. The American Convention and the Commission's regulations preclude the Commission from considering a complaint that is pending before another human rights tribunal or that is "substantially the same as one previously studied by the Commission." American Convention, supra note 26, art. 47(d), S. Exec. Doc. F, 95-2, at 54, 1144 U.N.T.S. at 152; Reg. Inter-Am. C.H.R., art. 39(1) (b), reprinted in Inter-Am. Ct. H.R., Basic Docunıents Pertaining to Human Rights in the InterAmerican System 75, 89, OEA/Ser.L.V/Il.71, doc. 6 rev. 1 (1987). Although the defendants apparently provided the Commission with additional information after its 1984 ruling, that in itself does not explain the Commission's failure to follow its established rules of procedure. In addition, the Commission never published the 1987 decision in its official annual report and its existence became widely known only when the Privy Council issued its ruling in the case six years later. Schabas, supra note 160, at 287.

168. See Schabas, supra note 160, at 287 (discussing and quoting unpublished Commission decision).

169. Pralt, [1994] 2 A.C. at 24-26.

170. Pratt, U.N. Doc. A/44/40, at 222 . The Committee cautioned, however, that in capital cases "an assessment of the circumstances of each case would be necessary." ld. For 
Again Jamaica equivocated over whether to carry out the death sentences while it considered what legal weight to afford the tribunals' recommendations. The defendants then filed a motion for constitutional redress, which the Jamaican courts rejected. ${ }^{171}$ When the Privy Council finally reviewed the defendants' constitutional claims, they had been incarcerated on death row for more than fourteen years.

1n its November 1993 decision, the Privy Council canvassed the differing approaches to the death row phenomenon adopted by national courts and by the ECHR in the eleven years since its earlier judgment. Although these courts were divided over the issue, the Privy Council sided with those domestic and international jurists who had found prolonged detention on death row incompatible with constitutional or treaty-based bans on inhuman or degrading treatment or punishment. ${ }^{172}$ The Privy Council acknowledged that much of the delay between sentence and execution could be attributed to capital defendants' efforts to invoke all available appellate procedures, and not necessarily to government error or flaws in the criminal justice system. Nevertheless, the court concluded that "[i]f the appellate procedure enables the prisoner to prolong the appellate hearings over a period of years, the fault is to be attributed to the appellate system that permits such delay and not to the prisoner who takes advantage of it." 173

Turning to the question of remedies, the Privy Council considered how to balance the government's interest in speedy post-conviction review of capital cases against a defendant's interest in a full and fair hearing of his legal challenges. Facing a Jamaican judicial system that was slow and unresponsive, the court held that a delay in carrying out an execution exceeding five years would be presumptively unconstitutional and require a commutation of the death sentence to life imprisonment. Within this five-year window, the court allocated approximately two years to complete all domestic appeals and eighteen months to petition the Human Rights Committee. ${ }^{174}$ Because Pratt and Morgan's death row de-

a discussion of the Committee's subsequent death row case law, see Helfer, supra note 1 , at 327-31.

171. Pratt, [1994] 2 A.C. at 27. Section 25 of the Constitution of Jamaica allows any person alleging that any of his or her rights under the Constitution have been violated to "apply to the Supreme Court for redress." Jam. Const. ch. Ill, \$25(1).

I72. Pratt, [1994] 2 A.C. at 30-33 (discussing decisions from Canada, ECHR, India, United States, and Zimbabwe).

I73. Id. at 33 .

174. ld. at 35. The court in Pratt appeared to hold that this eighteen-month period applied to petitions filed only with the Human Rights Committee. In a later ruling, however, the Privy Council suggested that the eighteen-month window was applicable even where a death row defendant petitioned both the Committee and the Inter-American Commission in succession. See Thomas v. Baptiste, [2000] 2 A.C. 1, 21 (P.C. 1999) (appeal taken from Trin. \& Tobago) (stating that state could have prescribed for the tribunals a maximum of eighteen months for death row defendants to complete international petitions "whether the petitioner made only one application or applied successively to more than one international body or made successive applications to the same body"). 
tention substantially exceeded this five-year limit, the Privy Council held that " $[\mathrm{t}]$ o execute these men now after holding them in custody in an agony of suspense for so many years would be inhuman punishment within the meaning of" the Jamaican Constitution. ${ }^{175}$

3. The Domestic Effects of Pratt. - The Pratt case had an immediate and extreme impact on Caribbean criminal justice systems. Jamaica promptly commuted the death sentences of 105 prisoners already detained on death row for more than five years. Trinidad \& Tobago commuted the sentences of fifty-three death row inmates and Barbados commuted nine death sentences. ${ }^{176}$ Local appellate courts put other cases on hold to concentrate on capital appeals. ${ }^{177}$ And ambiguities in the decision and its application to other Caribbean states compelled the Privy Council to devote a considerable portion of its docket to death row appeals from Caribbean courts between 1994 and 2000. ${ }^{178}$

The Pratt case also radically altered perceptions of the Privy Council among government officials, local judges, and some legal elites, who condemned its "revolutionary" break from past jurisprudence, its usurpation of Caribbean legislative powers, and the "great dislocation" it engendered in "the system of the administration of justice."179 The court's stature also declined among the Caribbean public, who criticized the overturning of death sentences by "London judges who did not have to live with the consequences of their decisions." 180 Eventually, both expert and popular opinion came to view Pratt as an attempt to undermine use of the death penalty, which had become a popular tool for combating the region's escalating murder rates. ${ }^{181}$

4. The International Effects of Pratt. - Pratt also had a pronounced effect on the international human rights regimes to which Caribbean states were parties. To understand why, recall that the Privy Council's

175. Pratt, [1994] 2 A.C. at 33.

176. David Simmons, Judicial Legislation for the Commonwealth Caribbean: The Death Penalty, Delay and the Judicial Committee of the Privy Council, 3 Caribbean L. Bull. 1, 6 (1998) [hereinafter Simmons, Death Penalty].

177. De La Bastide, supra note 150, at 407; see also Ramesh Lawrence Maharaj, The Death Penalty: Legal and Constitutional Issues, 9 Caribbean L. Rev. 137, 152 (I999) (noting "legislative and administrative reforms" of the domestic appeals process).

178. See Bob Howard \& Anne Westcott, Death Under the Sun, The Times (London), Jan. 18, 2000, at D16 (reporting statement by Privy Council judge that twenty-five percent of court's docket is devoted to death row appeals from the Commonwealth Caribbean).

179. Antoine, supra note 118, at 81,109 ; see also De La Bastide, supra note 150 , at 407-08 ("The question, however, is whether these are the sorts of decisions that should be taken in London by judges who have no contact at first hand with the societies to whom the decisions apply.").

180. O'Neill, supra note 152 , at 192.

181. Id. at 193; Simmons, Death Penalty, supra note 176, at 2 (Attorney General of Barbados asserting that Prall "frustrated the desires of Governments in this region to carry out the death penalty" and "infuriated populations who see their Governments rendered virtually powerless by decisions of legal policy set . . . by judges sitting in London and applying British and European notions"). 
choice of a five-year execution window was influenced by two factors. The first was the court's assessment of the functions and permissible delays of the domestic appellate process, a subject with which it was intimately familiar as the region's court of last resort. The second factor was the court's appraisal of the functions and abilities of human rights tribunals, a subject about which it was far less knowledgeable. ${ }^{182}$ This lack of understanding had serious consequences for the region's human rights regimes.

Consider first the Privy Council's statements in Pratt regarding the Inter-American Commission and the Human Rights Committee. The court expressed a generally positive view of the tribunals' roles in reviewing death row petitions. Notwithstanding the fact that the tribunals' decisions were not legally binding, the court took pains not to "discourage Jamaica from continuing its membership of these bodies and from benefiting from the wisdom of their deliberations,"183 and urged that their decisions "be afforded weight and respect" by the government. ${ }^{184}$ But the Privy Council also stated that either tribunal should complete its review of a petition "with reasonable dispatch and at most within eighteen months," and that petitions were likely to be "infrequent" once Jamaica eliminated the delays for domestic appeals. ${ }^{185}$

Both of these predictions were based on a misperception of how human rights petition procedures function. As for the time required to review death row petitions, the court in Pratt failed to recognize the tribunals' institutional incapacity to review cases quickly. ${ }^{186}$ The tribunals are part-time bodies which meet only a few times per year and manage an increasingly crowded docket with inadequate material and financial resources. ${ }^{187}$ For these reasons, each tribunal generally takes up to two years-and often longer-to process each case from its initial filing to a

182. For example, in a decision applying the Pratt principle to the Bahamas, the Privy Council initially set the execution window at three years and six months based on its conclusion that the Bahamas had failed to ratify either the American Convention or the Optional Protocol and thus no international petition procedures were available to individuals. Henfield v. Attorney Gen. of Bah., [1997] 1 A.C. 413, 423-25 (P.C. 1996) (appeal taken from Bah.). The court later corrected this error, recognizing that individuals could still petition the 1nter-American Commission concerning alleged violations of the American Declaration of the Rights and Duties of Man. Fisher v. Minister of Pub. Safety \& Immigration, [1998] 1 A.C. 673, 684-85 (P.C. 1997) (appeal taken from Bah.).

183. Pratt v. Attorney Gen. for Jam., [1994] 2 A.C. 1, 35 (P.C. 1993) (appeal taken from Jain.).

184. 1d. at 27.

185. 1d. at 35 .

186. Not until seven years later, after the denunciations had occurred, did the Privy Council acknowledge that "human rights bodies meet infrequently and are undermanned so that as things stand delays [beyond eighteen months] are almost inevitable." Lewis v. Attorney Gen. of Jam., [2001] 2 A.C. 50, 80 (P.C. 2000) (appeal taken from Jam.).

187. See Helfer \& Slaughter, supra note 7, at 347-48; Cathleen Caron, News from the Inter-American System, 7 Hum. Rts. Brief 13, 13 (1999). 
final decision on the merits. ${ }^{188}$ ln addition, the Privy Council failed to account for the fact that individuals can file petitions with the tribunals consecutively-by first petitioning the Inter-American Commission and, after it issues a decision, filing a second petition containing the same allegations with the Human Rights Committee. ${ }^{189}$ Thus, even assuming one tribunal could complete its review within eighteen months, the Privy Council made no allowance for an appropriate period of delay for cases in which capital defendants petitioned both tribunals.

5. The International Response to Pratt. - Taken together, the Privy Council's unduly optimistic timetable for supranational review and its failure to consider the filing of petitions with both tribunals created hydraulic pressure on Commonwealth Caribbean governments. On the one hand, the petition procedures they ratified would be utterly meaningless if they did not delay carrying out executions until the tribunals had concluded their review. ${ }^{190}$ On the other hand, by awaiting the tribu-

188. See Inter-Am. Comm'n on Human Rights, Non-Commuted Death Penalty Cases from the English-Speaking Caribbean: Statistics, at 2 n.5 (Jan. 2001) (on file with the Columbia Law Review) [hereinafter Inter-American Commission Death Penalty Statistics] (noting that Commission takes on average between twenty-four and thirty-six months to process petitions); Oldrich Andrysek, Gaps in International Protection and the Potential for Redress Through Individual Complaints Procedures, 9 Int'l J. Refugee L. 392, 403 (1997) (noting similar time periods for process petitions filed with Human Rights Committee). For a discussion of changing patterns of delay after Pratt, see notes 194-195 and accompanying text and Figure 3.

I89. Pratt and Morgan had followed this very approach, extending the international review of their respective claims to a total of more than six years. Petitioning the tribunals in a different order is not permitted, however. See American Convention, supra note 26, art. 47(d), S. Exec. Doc. F, 95-2, at 54, 1144 U.N.T.S. at 156 (stating that Inter-American Conmmission "shall consider inadmissible any petition or communication ... if . . [ $\mathrm{t}$ ] petition or communication is substantially the same as one previously studied by the Commission or by another international organization"). For a discussion of the different approaches to "successive petition forum shopping," see Helfer, supra note 1, at 306-07.

190. This is not to suggest that Caribbean governments habitually honored the tribunals' requests for interim measures seeking to prevent executions of defendants whose petitions were pending. To the contrary, the governments often refused to accede to the tribunals' requests for a stay and ignored their recommendations to commute death sentences. See Prince v. Trinidad \&c Tobago, Case 12.005, Inter-Am. C.H.R. 264, OEA/ ser.L/V/II.102, doc. 6 rev. 7-8 (I999), available at http://www.cidh.oas.org/annualrep/ 98eng/Admissibility/T\&T\%20I2005.htm (on file with the Columbia Law Review) (noting the first instance in which Trinidad \& Tobago complied with a request to stay an execution); Guerra v. Trinidad \& Tobago, Communication Nos. 575 \& 576/1994, U.N. GAOR, Hum. Rts. Comm., 50th Sess., Supp. No. 41, at 198-99, U.N. Doc. CCPR/C/57/1 (1996) (noting that government declined to give assurances that it would comply with Committee's request for interim measures not to execute defendant but stating that it was already bound by a domestic court's conservatory order preventing such execution); see also United Nations, Human Rights Committee, Consideration of Communications Under the Optional Protocol to the Covenant: Communication from Mr. Ashby, U.N. Doc. CCPR/C/SR.1352 (1996), available at http://www.unhchr.ch/tbs/doc.nsf/(Symbol)/ CCPR.C.SR.1352.En?Opendocument (on file with the Columbia Law Review) (noting Trinidad \& Tobago's refusal to comply with request for interim measures not to execute defendant who had filed petition with the Committee, and noting that States parties had 
nals' decisions, states risked running the five year clock and thus losing the ability to carry out any executions, even in cases where the tribunals' review ultimately disclosed no human rights violations.

This pressure was not lost on capital defendants and their council. As the following charts reveal, ${ }^{191}$ the number of death row petitions increased markedly in the years following Pratt. As shown in Figure 1, the number of petitions grew from between three and fifteen per year between 1989 and 1993 to between twenty-two and twenty-eight per year between 1994 and 1999. This increase was not spread evenly across the two tribunals, however. The Human Rights Committee received the overwhelming majority of cases filed in 1995 and 1996, whereas the lnterAmerican Commission received the bulk of the cases filed between 1997 and 1999. In addition, as illustrated in Figure 2, Jamaica and Trinidad \& Tobago-the Caribbean states with the region's largest death rows ${ }^{192}$ were the targets of the overwhelming majority of death row petitions both before and after the Privy Council's ruling.

Data concerning the time expended by the two tribunals to process death row petitions is also illuminating, particularly in light of the assertions by Trinidad \& Tobago and Jamaica (discussed below) that the tribunals were dilatory in reviewing death row petitions. With respect to the Human Rights Committee, Figure 3 reveals that between 1989 and 1993 (the year of the Pratt ruling), the Committee took on average between forty-four and fifty-six months to review petitions from initial filing to a final decision on the merits. After Pratt was decided, the review period increased slightly to a peak of forty-six months for petitions filed in 1995, but declined sharply to twenty-five months for petitions filed in 1996, fifteen months for petitions filed in 1997, and nineteen months for petitions filed in 1998. In all but one instance, however, these time periods

complied with such requests in more than 100 cases of defendants under sentence of death); Follow-up Activities Under the Optional Protocol, U.N. GAOR, Hum. Rts. Comm., 50th Sess., Supp. No. 40 vol. 1, at 92, U.N. Doc. A/50/40 (1995), available at http://www. unhchr.ch/tbs/doc.nsf/898586bldc7b4043c1256a450044f331/bbd592d8d48a76fec12563f 000586adc/\$F1LE/N9602481.pdf (on file with Columbia Law Review) (noting Jamaica's explicit refusal to implement the Committee's recommendations in nine cases decided under the Optional Protocol).

191. These charts were generated from a database of information collected from 200 petitions filed by criminal defendants under sentence of death between 1989 and 1999 , inclusive, against Commonwealth Caribbean states subject to the jurisdiction of the U.N. Human Rights Committee or the Inter-American Commission on Human Rights. See Database of Caribbean Death Row Human Rights Petitions (copy on file with author and with the Columbia Law Review). The database, which contains information current as of October 2001, includes petitions filed by defendants who received capital sentences that were later commuted. lnformation about the petitions in the database was obtained from published admissibility and merits decisions and from statistical information provided by the Inter-American Commission. Although case-specific information on unpublished decisions is confidential, inquiries made to the secretariats of both tribunals indicate that the number of unpublished decisions during this time period was extremely small.

192. See State Killing, supra note 156, at 3 (noting 2001 figures). 
FIGURE 1

Death Row Petitions from Commonwealth Caribbean Nations Filed with Human Rights Committee (UNHRC) and 1NTER-AMERICAN COMMISSION (IACHR)

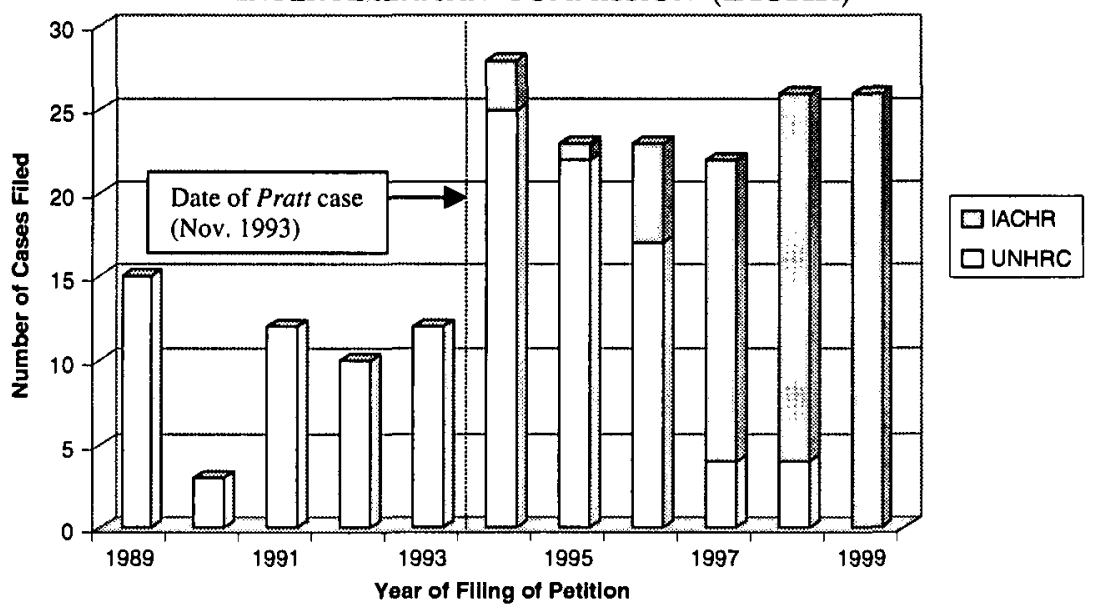

Figure 2

Death Row Petitions Filed with Human Rights Committee (UNHRC) AND 1NTER-AMERICAN COMMISSION (IACHR) BY State ANd Tribunal

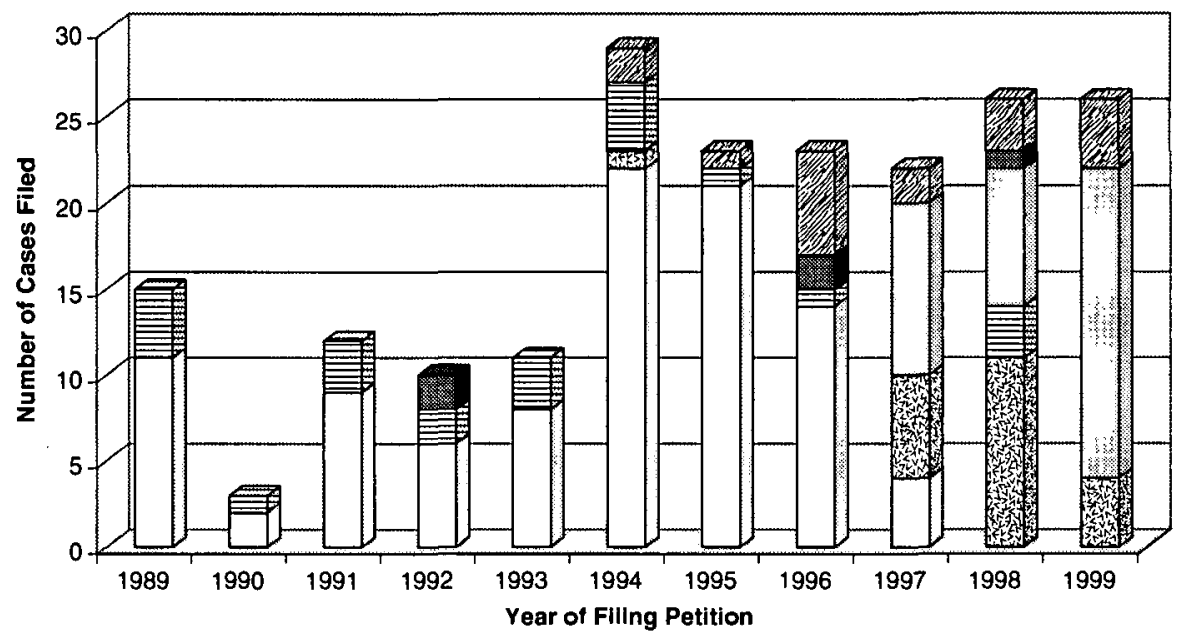

\begin{tabular}{|ll|}
\hline$\square$ Jamaica-UNHRC & Jamaica-IACHR \\
目 Trinidad \& Tobago-UNHRC & $\square$ Trinidad \& Tobago-IACHR \\
Other Caribbean-UNHRC & 囷 Other Caribbean-IACHR \\
\hline
\end{tabular}


exceeded the eighteen months allocated by the Privy Council for the tribunal to review petitions. ${ }^{193}$

The limited number of death row petitions filed with the Inter-American Commission prior to 1996 makes it difficult to assess the changes in review times before and after the Pratt case. With respect to petitions filed in 1996 and later, however, Figure 3 shows a rapid decline in review periods both for admissibility and merits decisions. ${ }^{194}$ In particular, the review period for decisions on the merits decreased from an average of thirty-six months for petitions filed in 1997 to fourteen months for petitions filed in 1999. ${ }^{195}$ Again, only in 1999 did review times decrease below the Privy Council's eighteen-month estimate.

Another trend that co-varied with the rise in the number of petitions after the Pratt case was an increase in and changing composition of the representatives assisting death row defendants. As Figure 4 illustrates, of the fifty-one death row defendants petitioning the tribunals between 1989 and 1993 , forty-six, or $90.1 \%$, appear to have been assisted by a third-party representative. The information from this period is incomplete, however. Many cases either fail to state whether a defendant was represented (in which case it is assumed that the defendant represented himself) or state that a defendant was represented without providing additional information. Where a British law firm or the advocacy group 1nterrights appeared on behalf of the defendant, however, the decisions clearly note that fact.

The representation patterns changed significantly in the wake of Pratt. A large majority of the 149 petitioners $(81.2 \%)$ during the period from 1994 to 1999 were represented by British law firms (often on a pro

193. The average review periods in Figure 3 for the Human Rights Committee's admissibility decisions includes only those petitions that the Committee declared inadmissible.

194. The dates on which the Commission decided the admissibility of petitions from death row defendants was not always made public in the case of petitions filed against Trinidad \& Tobago that were later referred to the Inter-American Court. 1n such instances, the date on which the Commission requested that the Court adopt provisional measures directing the state not to execute a defendant was substituted for the date of the admissibility decision. However, because the Commission's request for provisional measures usually preceded its determination of a petition's admissibility, this substitution reduces the average review periods for the Commission's "decisions on admissibility" as reflected in Figure 3. As a result, the actual average review periods are likely to be somewhat longer than those indicated in Figure 3.

195. This data tracks statistics collected by the Inter-American Commission, which aggregates average review periods for both admissibility and merits decisions in noncommuted death penalty cases against Jamaica and Trinidad \& Tobago. For Jamaica, the average review period declined from 27.5 months for petitions filed in 1997 to 10.5 months for petitions filed in 1998 and 7.6 months for petitions filed in 1999. For Trinidad, the average review period declined from twenty-three months for petitions filed in 1997 to fourteen months for petitions filed in 1998 and ten months for petitions filed in 1999 . Inter-American Commission Death Penalty Statistics, supra note 188, at 2 n.5. 
Figure 3

Review of Petitions to Human Rights Committee (UNHRC) and Inter-American Commission (IACHR) from Filing to Decision (ADMISSIBILITY AND MERITS)

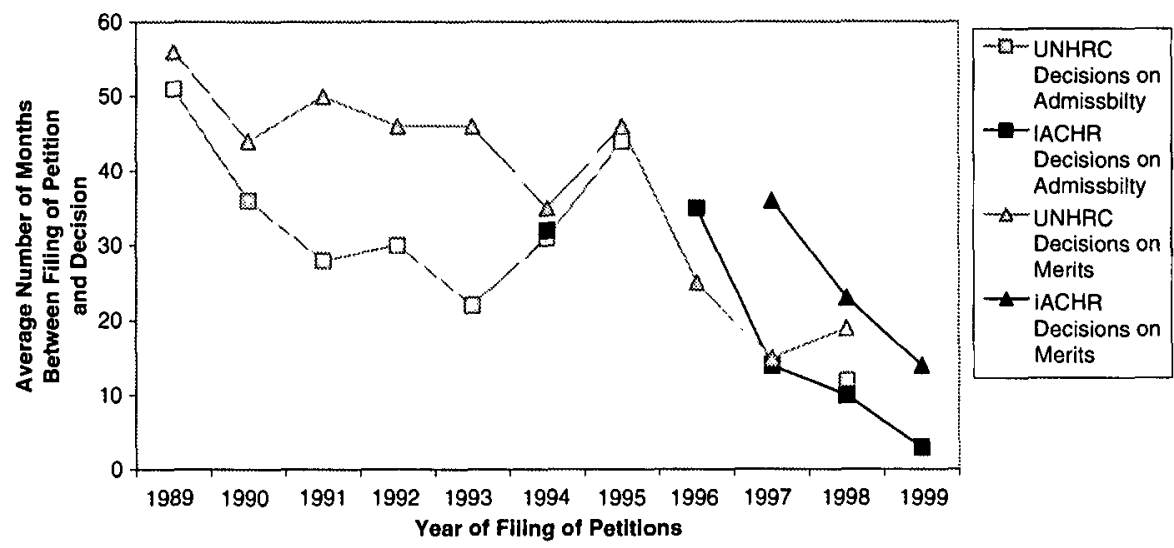

Figure 4

Representation of Death Row Defendants in Petitions from

Commonwealth Caribbean Nations Filed with Human Rights Tribunals

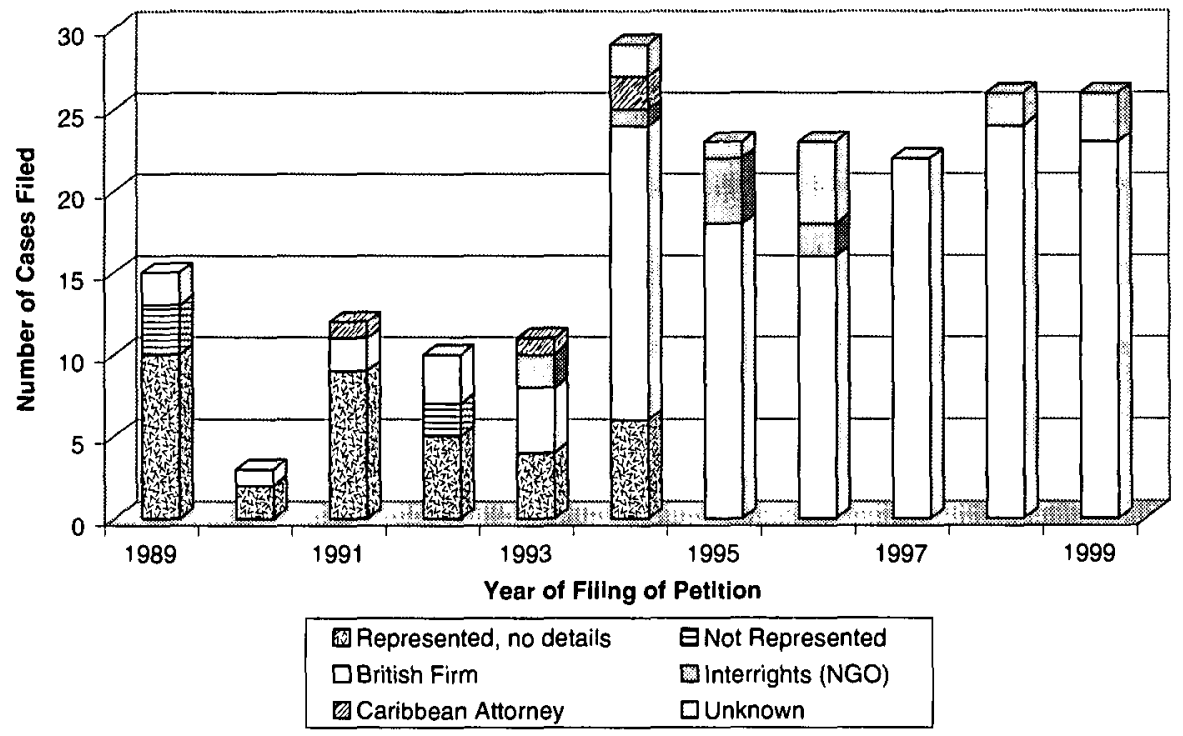


bono basis), ${ }^{196}$ with a smaller number $(4.7 \%)$ represented by 1 terrights. For those petitions for which information is available (136 of the 149 petitions), only two defendants were represented by Caribbean attorneys, and no defendants represented themselves.

6. The Domestic Response to Pratt. - When added together, the crowding of the tribunals' dockets and the delays in reviewing death row petitions often caused post-conviction review in capital cases to exceed the five-year execution window set in Pratt. Thus, simply by invoking domestic and supranational appellate review mechanisms, many capital defendants could effectively force Caribbean governments to commute their death sentences. ${ }^{197}$ The result was a near de facto abolition of the death penalty in Caribbean states subject to the Privy Council's jurisdiction, even though neither the 1CCPR nor the American Convention per se proscribes capital punishment. ${ }^{198}$

As the consequences of the Pratt ruling became clear, Caribbean governments and the Caribbean public began to perceive human rights tribunals as obstacles to imposing capital sentences and death row defendants as abusers of the tribunals' procedures. ${ }^{199} 1 \mathrm{n}$ an effort to meet the Privy Council's five-year deadline, governments had sought to expe-

196. See Penal Reform Int'l, Assistance for Prisoners Under Sentence of Death in the Commonwealth Caribbean, available at http://www.penalreform.org/english/ frset_region_en.htm (last visited Aug. 30, 2002) (on file with the Columbia Law Review) [hereinafter Assistance for Prisoners] (discussing pro bono assistance provided to death row defendants before Privy Council and human rights tribunals); O'Neill, supra note 152, at 196-97 (discussing letters sent by death row defendants to attorneys in the United Kingdom specializing in appeals before the Privy Council).

197. See Glenn McGrory, Reservations of Virtue? Lessons from Trinidad and Tobago's Reservation to the First Optional Protocol, 23 Hum. Rts. Q. 769, 778 (2001) (noting possibility of abolitionist lawyers "strategically seeking procedural delays" to commute death sentences for their clients).

198. See Scott Davidson, The Inter-American Human Rights System 267-74 (1997) (discussing circumstances under which the American Convention allows imposition of the death penalty); Natalia Schiffrin, Jamaica Withdraws the Right of Individual Petition Under the International Covenant on Civil and Political Rights, 92 Am. J. Int'l L. 563, 564 \& n.5 (1998) (noting that ICCPR does not prohibit capital punishment); see also Frances Williams, Jamaica Quits UN Accord, Fin. Times (London), Oct. 27, 1997, at 3 (characterizing the Pratt decision as creating "a de facto abolition of the death penalty").

199. See Christof Heyns \& Frans Viljoen, The Impact of the United Nations Human Rights Treaties on the Domestic Level, 23 Hum. Rts. Q. 483, 496 (2001) (noting that "official reason" for Jamaica's denouncement of the Optional Protocol was its frustration at delays in processing petitions by U.N. Human Rights Committee); Estrella Gutierrez, Rights-Americas: Trinidad and Tobago Stands Up to OAS, Inter Press Service, June 4, 1998, available at LEXIS, Inter Press Service File (on file with the Columbia Law Review) (reporting that Trinidad \& Tobago foreign minister characterized filing of petitions with multiple tribunals as "death row prisoners . . . abusing' ... recourse to human rights bodies”); Trinidad: Attorney-General Responds to Amnesty International's Charges, Cana News Agency, Apr, 18, 2000, available at LEXIS, BBC WorIdwide Monitoring File (on file with the Columbia Law Review) (quoting Trinidad \& Tobago Attorney General as stating that delay in reviewing claims by Human Rights Committee "has facilitated persons convicted of murder to escape the death penalty"). 
dite capital appeals in local courts. But they could not directly control the pace at which the tribunals reviewed international petitions. ${ }^{200}$

The governments initially sought relief from the Privy Council, arguing that the execution window set in Pratt was unreasonably short because "applications to the human rights bodies take on average two years."201 The governments requested that "either the periods of time relating to applications to the human rights bodies should be excluded from the computation of delay or the period of five years should be increased to take account of delays normally involved in the disposal of such complaints." ${ }^{02}$ The Privy Council categorically rejected this request, even in the face of a threat by Barbados to denounce the Optional Protocol if the court did not extend the time limits. ${ }^{203}$

Unable to ease the strictures of Pratt domestically, the two Caribbean governments with the largest death row populations next sought unilaterally to revise the tribunals' procedural rules to conform to the Privy Council's deadline. In August and October 1997, the Governors-General of Jamaica and Trinidad \& Tobago promulgated "instructions" to both tribunals that sought to impose detailed and precise timetables for review of death row petitions. ${ }^{204}$ According to the two governments, the instructions were an attempt "to co-operate with the international human rights institutions" while retaining the right to impose capital sentences within the time limits set in Pratt. ${ }^{205}$ If the tribunals followed the instructions, the governments agreed not to carry out executions while a petition was pending. But the time allocated to each tribunal was extremely short. To allow for the possibility that defendants would petition both tribunals in succession, the instructions granted seven months to each tribunal to complete its examination, far less time than either body had taken to review petitions in the past. Perceiving the instructions as threats to their authority, both tribunals refused to follow the instructions, ${ }^{206}$ and the Privy Council later invalidated them on constitutional grounds. ${ }^{207}$

200. McGrory, supra note 197 , at 777 ; Schiffrin, supra note 198 , at 566 .

201. Bradshaw v. Attorney Gen. of Barb., [1995] 1 W.L.R. 936, 941 (P.C. 1995) (appeal taken from Barb.).

202. Id.

203. Id.

204. Government Notice, Miscellaneous No. 150, I20 Jam. Gazette (Extraordinary) 945 (Aug. 7, 1997) (on file with the Columbia Law Review); Instructions Relating to Applications from Persons Under Sentence of Death, 36 Trin. \& Tobago Gazette (Extraordinary) 855 (Oct. 13, 1997) (on file with the Columbia Law Review).

205. Thomas v. Baptiste, [2000] 2 A.C. 1, 19 (P.C. 1999) (appeal taken from Trin. \& Tobago).

206. See, e.g., United Nations, Human Rights Committee, Consideration of Reports Submitted by States Parties Under Article 40 of the Covenant: Concluding Observations of the Human Rights Committee: Jamaica, U.N. Doc. CCPR/C/79/Add.83 (1997) (refusing to follow Jamaica's attempt to "unilaterally impos[e] timetables" for review of petitions).

207. Lewis v. Attorney Gen. of Jam., [2001] 2 A.C. 50, 85 (P.C. 2000) (appeal taken from Jam.); Thomas, [2000] 2 A.C. at 21. 
With their unilateral efforts to expedite review of death row petitions thwarted, Jamaica and Trinidad \& Tobago denounced their treaty obligations. But their denunciations, as well as that of Guyana, did not eliminate all avenues of supranational review. On October 23, 1997, Jamaica denounced the 1CCPR's First Optional Protocol, eliminating the right of individuals to petition the Human Rights Committee. ${ }^{208}$ Jamaica did not, however, withdraw from the American Convention, thereby preserving the right of aggrieved individuals to file complaints with the Inter-American Commission. As Figure 2 above illustrates, death row defendants in Jamaica capitalized on this remaining avenue of review by filing an unprecedented number of petitions with the Commission. But because Jamaica had never accepted the jurisdiction of the Inter-American Court, those complaints could only result in recommendations by the Commission rather than legally binding judgments of the court.

Trinidad \& Tobago's denunciations were more extensive. On May 26, 1998, the state denounced both the Optional Protocol and the American Convention. ${ }^{209}$ On the same date, it reacceded to the Optional Protocol with a broad reservation that sought to preclude the Human Rights Committee from reviewing any petitions from capital defendants. ${ }^{210}$ In a November 1999 decision, however, the Committee declared such a defendant's petition admissible, concluding that the reservation was incompatible with the object and purpose of the Optional Protocol and severable from the state's decision to reaccede to the treaty. ${ }^{211}$ In response, Trinidad \& Tobago denounced the Optional Protocol in its entirety on March $27,2000 . .^{212}$

Guyana's response was more curious. As noted above, Guyana had eliminated appeals to the Privy Council in 1970 and thus was not bound by the Pratt case. ${ }^{213}$ Its 1993 ratification of the Optional Protocol, in the year after its first free post-independence election, was motivated by the newly elected government's distrust of the local judiciary and its desire to make available to Guyanese an international body to review human rights

208. Optional Protocol Ratification Chart, supra note 138, at 226 n.1. Pursuant to Article 12 of the Optional Protocol, supra note 29, art. 12, Jamaica's denunciation became effective on January 23, 1998, three months after it was filed.

209. Pursuant to Article 12 of the Optional Protocol, supra note 29, art. 12, and Article 78 of the American Convention, supra note 26, art. 78, S. Exec. Doc. F, 95-2, at 61, 1144 U.N.T.S. at 161-62, the denunciation of the Optional Protocol took effect on August, 26, 1998 and the denunciation of the American Convention took effect on May 26, 1999, one year after it was filed.

210. The reservations prohibited the Human Rights Committee from receiving communications from "any prisoner who is under sentence of death in respect of any matter relating to his prosecution, his detention, his trial, his conviction, his sentence or the carrying out of the death sentence on him and any matter connected therewith." Optional Protocol Ratification Chart, supra note 138, at 229.

211. See Kennedy v. Trinidad \& Tobago, Communication No. 845/1999, U.N. GAOR, Hum. Rts. Comm., 55th Sess., Supp. No. 40 vol. 2, at 266, U.N. Doc. A/55/40 (1999).

212. Optional Protocol Ratification Chart, supra note 138, at 231 n.3.

213. See supra note 147 . 
abuses. $^{214}$ Yet when in March 1998 the Human Rights Committee issued its first decision against Guyana, recommending that two Guyanese death row defendants be released from prison, government officials criticized the Committee for violating national sovereignty. ${ }^{215}$ Guyana later denounced the Optional Protocol on January 5, 1999.216 On the same date, Guyana reacceded to the treaty with a death penalty reservation identical to the one previously filed by Trinidad \& Tobago. ${ }^{217}$

\section{Severing Links to the Privy Council and Creating a New Caribbean Court of Justice}

The denunciation of the human rights treaties and petition procedures by the three governments did not conclude the saga of the death row phenomenon in the Caribbean. Prior to May 26, 1999, the effective date of Trinidad's denunciation, thirty-two death row defendants in that country filed petitions with the Inter-American Commission. ${ }^{218}$ Beginning on June 14, 1998, the 1nter-American Court issued provisional measures directing the government not to execute these defendants pending a review of their claims by the Commission and the Court. ${ }^{219}$ Trinidad

214. Bert Wilkinson, Rights-Caribbean: Another Government Withdraws from UN Body, Inter Press Service, Nov. 18, 1998, available at LEX1S, Inter Press Service File (on file with the Columbia Law Review) [hereinafter Wilkinson, Another Government Withdraws]; Bert Wilkinson, Rights-Guyana: Let Prisoners Go Free, U.N. Body Says, lnter Press Service, May 19, 1998, available at LEXIS, Inter Press Service File (on file with the Columbia Law Review).

215. Yasseen v. Guyana, Communication No. 676/1996, U.N. GAOR, Hum. Rts. Comm., Supp. No. 40 vol. 2, at 162, U.N. Doc. A/53/40 (1998); Wilkinson, Another Government Withdraws, supra note 214.

216. Optional Protocol Ratification Chart, supra note 138, at 228, 231 n.2; Bert Wilkinsol1, Rights-Guyana: On the Verge of Restoring Executions, Inter Press Service, Sept. 25, 1999, available at LEXIS, Inter Press Service File (on file with the Columbia Law Review).

217. Optional Protocol Ratification Chart, supra note 138, at $231 \mathrm{n} .2$. After the Human Rights Comınittee's decision in Kennedy v. Trinidad \& Tobago, Communication No. 845/1999, U.N. GAOR, Hum. Rts. Comm., 55th Sess., Supp. No. 40 vol. 2, at 265-66, U.N. Doc. A/55/40 (1999), declaring Trinidad's death penalty reservation invalid, Guyana did not denounce the Optional Protocol entirely. Thus, all aggrieved individuals, including those on death row, may continue to file petitions with the Human Rights Committee. As of July 2002, seven petitions were pending against Guyana although their allegations are not publicly known. See Office High Comm'n Hum. Rts., U.N., Statistical Survey of Individual Complaints Dealt with by the Human Rights Committee Under the Optional Protocol to the lCCPR (2002), available at http://www.unhchr.ch/html/menu2/ 8/stat2.htm (on file with the Columbia Law Review).

218. See Hilaire v. Trinidad \& Tobago, Inter-Am. Ct. H.R. at 3-5 (June 21, 2002), available at http://www.corteidh.or.cr/T_y_t/Serie_c_94_ing.doc (on file with the Columbia Law Review) (collecting thirty-two cases referred by Inter-American Commission prior to May 1999).

219. Press Release, Inter-Am. Ct. H.R., Provisional Measures James et al., CDH-CP9/ 98 English (Sept. 1998), available at http://www1.umn.edu/humanrts/iachr/pr8-98.html (on file with the Columbia Law Review); see also Press Release, Inter-Am. Ct. H.R., James et al. Provisional Measures CDH-CP6/99 English (June 9, 1999), available at http:// 
publicly flouted the court's orders by issuing death warrants and by carrying out executions of some of the defendants. ${ }^{220}$

In March 1999, however, the Privy Council issued a divided, controversial ruling in which it held that the government would violate the due process clause of Trinidad \& Tobago's constitution if it executed defendants whose international petitions were still pending. ${ }^{221}$ The Privy Council thus stayed their executions pending the outcome of their appeals before the Inter-American Court ${ }^{222}$ (which, in June 2002, issued a judgment finding that Trinidad \& Tobago had violated the defendants' rights under the American Convention ${ }^{223}$ ). In September 2000, the Privy Council applied the same reasoning to the Jamaican constitution in an

www1.umn.edu/humanrts/iachr/pr16-99.html (on file with the Columbia Law Review) (extending provisional measures to additional defendants on death row in Trinidad \& Tobago). The Commission later found that the government had violated the defendants' rights under the American Convention, and it referred the cases to the Inter-American Court. Inter-American Commission Death Penalty Statistics, supra note 188, at 1 n.4 (noting referrals on May 25, 1999, Feb. 22, 2000, and Oct. 25, 2000). For a discussion of the court's judgment finding that Trinidad had violated the defendants' rights under the American Convention, see infra note 223.

220. See McGrory, supra note 197, at 773 \& $\mathrm{n} .16$ (discussing hangings in violation of Inter-American Court's orders); State Killing, supra note 156, at 22 (reporting that "Trinidad and Tobago has continued to execute defendants before the completion of the international judicial process" and refuting the state's denial that the executions are in violation of the lnter-American Court's orders); Trinidad: Attorney-General Rejects lnterAmerican No-Executions Order, Cana News Agency, June 25, 1998, available at LEXIS, BBC Worldwide Monitoring File (on file with the Columbia Law Review) (reporting statement by Attorney General of Trinidad \& Tobago that "state does not plan to respond to a 'no-executions' order from the Inter-American Court on Human Rights").

221. Thomas v. Baptiste, [2000] 2 A.C. 1, 21-24 (P.C. 1999) (appeal taken from Trin. \& Tobago).

222. Id. at 24, 29.

223. See Hilaire v. Trinidad \& Tobago, Inter-Am. Ct. H.R. at 70-72 (June 21, 2002), available at $h$ ttp://www.corteidh.or.cr/T_y_t/serie_c_94_ing.doc (on file with the Columbia Law Review). The court found violations of, inter alia, the right to life, the right to be tried within a reasonable time, the right to an effective recourse, the right to humane treatment, and the right of all persons sentenced to the death penalty to apply for amnesty, pardon, or commutation of their sentence. ld. The court held that Trinidad was obligated, inter alia, to amend the Offences Against the Person Act to remove "the mandatory death penalty," to retry the defendants under the amended criminal code, to modify the conditions of its prisons to conform to international human rights standards, to commute the death sentences of those defendants who had not been executed, and to pay compensation with respect to one defendant. 1d. at 39, 72-74. The Attorney General of Trinidad \& Tobago has responded publicly to the judgment. Gov't Info Servs., Gov't of the Republic of Trin. \& Tobago, The Attorney General Responds to the Ruling of the Inter American Court on Human Rights (July 10, 2002), at http://www.gov.tt/news/ AGHumaRightsResponse.asp (on file with the Columbia Law Review). She noted that the government will amend the Offences Against the Person Act and that the Privy Council's Pratt decision will eventually bar the defendants' executions. Id. It is unclear from her statement, however, what other measures, if any, the government will take to comply with the Inter-American Court's judgment. See id. 
appeal brought by six death row defendants who had filed petitions with the Human Rights Committee and the Inter-American Commission. ${ }^{224}$

The pressure created by these decisions led Caribbean governments to cut their ties to the Privy Council. In February 2001, eleven Caribbean states finalized an agreement to replace the British court with a new Caribbean Court of Justice which will act as the region's highest court of appeal. ${ }^{225}$ Pressure to ratify the agreement increased in the spring of 2002 after the Privy Council ruled that the mandatory imposition of death sentences for all murder convictions was unconstitutional. ${ }^{226}$ Once the agreement enters into force, the link between the Commonwealth Caribbean and the Privy Council will be severed, and with it, many human rights advocates fear, the last bar to wholesale imposition of the death penalty in the Caribbean. ${ }^{227}$

\section{Caribbean Human Rights Protections in the Twenty-first Century}

In closing this Part, a brief review of the consequences of the Caribbean backlash against human rights seems warranted. Although the foregoing narrative has focused on issues relating to capital punishment, the impact of the governments' actions are in fact far broader and have left the regional legal landscape relating to human rights protection in a state of flux.

First, the backlash narrowed the opportunities for supranational review of human rights violations. Individuals in Jamaica and Trinidad \& Tobago, the region's two most populous states, ${ }^{228}$ can no longer petition

224. Lewis v. Attorney Gen. of Jam., [2001] 2 A.C. 50, 85 (P.C. 2000) (appeal taken from Jam.).

225. See Canute James, Controversial Caribbean Court Will Go Ahead, Fin. Times (International), Feb. 20, 200I, available at WL Fintimes Database (on file with the Columbia Law Review); Caribbean: Eleven Caribbean Leaders Sign Agreement to Set Up Caribbean Court of Justice, BBC Monitoring Summary of World Broadcasts, Feb. 17, 2001, at L/I (agreement signed Feb. I5, 200I). The court will commence operations once three countries have ratified the agreement and deposited five years of dues in a special trust fund. See Owen Bowcott, Caribbean Severs Link to Privy Council, The Guardian (Manchester), Feb. I5, 2001, at 12. The court is "unlikely to sit before 2003." Id.

226. See Reyes v. The Queen, Appeal No. 64 of 2001, If 43 (P.C. Mar. 11, 2002) (appeal taken from Belize), available at http://www.privy-coumcil.org.uk/files/pdf/ 2002_No.11.pdf (on file with the Columbia Law Review) (holding that mandatory death penalty for appellant's conviction of murder by shooting violates prohibition on inhuman or degrading punishment in Constitution of Belize); Canute James, Death Penalty Ruling Could Speed Up Plans for Caribbean-wide Court, Fin. Times. (U.S.), Mar. 15, 2002, available at WL Fintimes Database (on file with the Columbia Law Review) (stating that Caribbean governments are expected to speed up plans to establish Caribbean Court of Justice in wake of Privy Council's ruling).

227. See Bowcott, supra note 225, at I2 ("The decision to establish a shared Caribbean court of justice-advocated as a means of establishing full legal independence for the region and throwing off one of the last vestiges of colonialism-is likely to speed up the rate of hangings.").

228. The World Almanac and Book of Facts, at 867-68 (William A. McGeveran Jr. ed., 2002). 
the Human Rights Committee regarding violations of any of the rights guaranteed under the 1CCPR-including rights wholly unrelated to the criminal justice system. ${ }^{229}$ If the demand for international review remains high, this may increase the workload of the lnter-American Commission, which retains the authority to review petitions alleging violations of the American Convention (in the case of Jamaica) or the nonbinding American Declaration of the Rights and Duties of Man (in the case of Guyana and Trinidad, which are parties to the OAS Charter but not to the American Convention). ${ }^{230}$ Opportunities for supranational review in the remainder of the region are only slightly more promising. ${ }^{231}$

Second, the backlash fundamentally altered domestic judicial procedures for protecting human rights. Once the Caribbean Court of Justice commences operations, it will have the ultimate authority to interpret the region's constitutions. The new court will thus be empowered to decide whether to follow the Privy Council's precedents across a wide range of civil liberties issues, and whether to construe the bills of rights in Caribbean constitutions in harmony with international human rights standards. Although the Law Lords had begun to adopt broad and purposive

229. Guyana is still a party to the Optional Protocol because its reservation covering the death penalty is likely to be viewed as invalid by the Human Rights Committee. See supra text accompanying note 211 (describing the Committee's invalidation of Trinidad \& Tobago's death penalty reservation, which is identical to Guyana's). All three states continue to be parties to the ICCPR, and thus are obligated to submit periodic reports to the Human Rights Committee on the measures tbey have taken to protect the rights in the Covenant. In practice, however, such reports are often late and only partly illuminate the human rights situation in a particular state. See Anne F. Bayefsky, The UN Human Rights Treaty System: Universality at the Crossroads 8, 21 (2000). It is for this reason that individual petition procedures are often seen as the most effective way to review compliance with human rights treaties. See Rein A. Myullerson, Monitoring Compliance with International Human Rights Standards: Experience of the UN Human Rights Committee, 1991-1992 Canadian Hum. Rts. Y.B. 105, 107 (1992) (“[I]t is only through the consideration of individual communications that complete conformity of national legislation and practice with the requirements of international law can be assessed.").

230. See Natasha Parassram Concepcion, Note, The Legal Implications of Trinidad \& Tobago's Withdrawal from the American Convention on Human Rights, 16 Am. U. Int'l L. Rev. 847, 861-62 (2001) (noting that even after Trinidad \& Tobago's denunciation of American Convention, individuals may still file petitions with the Inter-American Commission alleging violations of the American Declaration on the Rights and Duties of Man). The Commission's decisions interpreting the Declaration are not legally binding, however, and may not be referred to the Inter-American Court. Id. at 859-60.

231. Because all twelve states that comprise the Commonwealth Caribbean are members of the OAS, OAS Ratification Chart, supra note 139, the 1nter-American Commission may receive communications alleging that these states have violated the nonbinding American Declaration. Concepcion, supra note 230, at 860 . Of the twelve states, only Barbados is a party to both the American Convention and the 1CCPR's Optional Protocol. St. Vincent \& the Grenadines is also a party to the latter treaty. American Convention Ratification Chart, supra note 84; Optional Protocol Ratification Chart, supra note 138. Although Barbados threatened to denounce the American Convention after the Pratt case, see Gutierrez, supra note 199, neither it nor any other state in the region withdrew from their human rights treaty obligations. 
constructions of the constitutions that considered international treaties and decisions as persuasive authorities, ${ }^{232}$ it is unknown whether the Caribbean Court of Justice will continue this approach.

\section{II. Viewing the Caribbean Backlash Through Three Optics}

What explains the actions of these Caribbean governments? The number and variety of state and nonstate actors involved in these events and the complexity of their interactions suggest that no single factor can be identified as the definitive cause of the backlash. It is possible, however, to achieve greater explanatory clarity by viewing the events through three different optics-one focused on the Caribbean backlash as a dispute over capital punishment, the second addressing the judicial imperialism of the Privy Council, and the third emphasizing the overlegalization of international obligations. Each of these optics emphasizes the causal contributions of a particular facet of the Caribbean case study. Filtering the denunciations through these three lenses reveals that although certain aspects of the backlash are unique to the region and unlikely to be replicated elsewhere, other features may prove informative for other treaty regimes and the ways in which those regimes might become overlegalized.

\section{A. The Caribbean Backlash as a Capital Punishment Dispute}

One optic focuses on the Caribbean treaty denunciations as principally if not exclusively caused by a dispute over the death penalty. Governments, legal elites, and the Caribbean public shared a strong preference for capital punishment as a way to deter the region's persistently high violent crime rate. According to one official (the Attorney General of Trinidad \& Tobago), the legality of the death penalty was an essential condition of Caribbean participation in human rights regimes. ${ }^{23.3}$ The

232. See Reyes v. The Queen, Appeal No. 64 of 2001, II 17-24, 26, 40-42 (P.C. Mar. 11, 2002) (appeal taken from Belize), available at http://www.privy-council.org.uk/files/ pdf/2002_No.1 l.pdf (on file with the Columbia Law Review) (stating that "[a] generous and purposive interpretation is to be given to constitutional provisions protecting human rights," and citing American Convention, European Convention, ICCPR, and decisions of Inter-American Commission, ECHR, and the Human Rights Committee as persuasive authority). For additional Privy Council decisions referring to international human rights sources, see Attorney Gen. of H.K. v. Lee Kwong-Kut, [1993] A.C. 951, 953, 967-68 (P.C. 1993) (appeal taken from H.K.) (citing decisions of ECHR and comments of Human Rights Committee); Vincent v. The Queen, [1993] 1 W.L.R. 862, 868 (P.C. 1993) (appeal taken from Jam.) (referring to decision of Human Rights Conmittee); Riley v. Attorney Gen. of Jam., [1983] A.C. 719, 720 (P.C. 1982) (appeal taken from Jam.) (citing to decision of ECHR); Ong Ah Chuan v. Pub. Prosecutor, [1981] A.C. 648, 651 (P.C. 1980) (appeal taken from Sing.) (citing decisions of ECHR); see also supra Part II.A.3 (discussing methodological approach of Privy Council to interpreting Caribbean constitutions).

233. Maharaj, supra note 177 , at 150 ("It was on this basis that . . Commonwealth Caribbean States organised their domestic legal and administrative procedures in capital cases and it was on this understanding that Trinidad and Tobago accepted the right of condemned prisoners to petition the international human rights bodies."). 
evolution of capital punishment norms supports this claim. When Caribbean states first ratified human rights treaties, between the 1960s and the $1980 \mathrm{~s}$, the text of the treaties, the case law of the tribunals, and the judgments of the Privy Council all supported the view that death sentences and delays in executing them did not violate international or constitutional law. Restrictions on capital punishment existed, but moves toward abolition were only encouraged, not required.

The legal norms governing capital punishment shifted after the Pratt case, but the Caribbean preference for capital punishment did not. Initially, governments sought to reconcile their human rights commitments with their intent to carry out executions. But when faced with a perceived irreconcilable conflict between their domestic commitment to the death penalty and their international commitment to the human rights petition system, the governments chose exit-first from the tribunals' jurisdiction, and then, when that failed to ease constraints on executions, from the Privy Council. In the end, the regional preference for capital punishment was strong enough to outweigh the weaker preference for maintaining commitments to constitutional and human rights systems that effectively incorporated abolitionist norms. Supporting this conclusion is the fact that two of the three denouncing states immediately sought to reaffirm their treaty commitments for human rights unrelated to capital punishment.

Viewed as a story about the death penalty, the case study at first appears to have little resonance beyond its particular facts. Examined more broadly, however, the study provides evidence of how states may respond when international agreements expand into areas that clash with strongly held domestic preferences. Such norm shifts can create a form of overlegalization by increasing a treaty's levels of obligation and precision. ${ }^{234}$ Norm shifts are particularly prevalent in the human rights arena, where treaties under the stewardship of international tribunals have been imbued with an inherently expansionist character. ${ }^{235}$ But they are also plausible outcomes in areas as diverse as trade, intellectual property, arms control, or environmental law, where the consequences of treaty ratification become clear only after agreements are interpreted by international bodies or applied by the parties over time to a diverse series of factual settings.

The plausibility of an exit strategy in response to norm shifts will vary depending upon such variables as: (1) the mix of obligations and institutions a treaty contains; (2) the costs to a state's reputation and to the

234. See supra Part I.D.1 (describing overlegalization that changes initial treaty bargains).

235. See Laurence R. Helfer, Consensus, Coherence and the European Convention on Human Rights, 26 Cornell lnt'l L.J. 133, 134 (1993) (analyzing ways in which ECHR has expanded the European Convention to keep pace with evolving legal standards). 
credibility of its commitment to comply with other treaties; ${ }^{236}$ and (3) the willingness of a state to eschew exit in exchange for a greater voice in shaping the regime's future. ${ }^{237}$ Commitments negotiated as a "package deal," such as the WTO's family of agreements, are likely to be far stickier than single-subject treaties or treaties that permit issue-specific reservations ex ante. ${ }^{238}$ But the Caribbean backlash demonstrates that the potential for exit is genuine, even for relatively robust treaty systems and states once committed to some form of international supervision.

\section{B. The Caribbean Backlash as a Consequence of Judicial Imperialism}

A second framing of the case study focuses on the Privy Council as an illegitimate legacy of colonialism. On this reading, the backlash achieved the judicial independence that was an inevitable, if delayed, consequence of earlier political independence. So long as the Privy Council's judgments were consonant with local values, the benefits of retaining appeals to London-free justice from learned jurists incorruptible by local politicians-outweighed the court's status as a vestige of colonial rule. But once the court began to articulate norms in conflict with local values, the court came to be perceived as engaging in a form of "judicial imperialism" 239 by "super-impos[ing] . . E Eurocentric notions and values" on the region. ${ }^{240}$

236. That Jamaica and Trinidad \& Tobago believed that the credibility costs of exit were high is suggested by their efforts to remain as treaty parties after the Prall decision. Rather than denouncing the treaties immediately, the governments first sought to convince the Privy Council and then the human rights tribunals to extend review periods in capital cases. See supra text accompanying notes 201-207.

237. See Weiler, supra note 14, at 2412, 2423, 2427 (arguing that members of the European Community began to exercise greater voice in EC's decisionmaking processes as their option to exit the Community diminished).

238. See Steve Charnovitz, Triangulating the World Trade Organization, 96 Am. J. Int'1 L. 28, 31 (2002) (stating that negotiators of Uruguay Round trade agreements sought "a 'package deal' of interlocked commitments rather than a collection of stand-alone agreements"); Ernst-Ulrich Petersmann, Constitutionalism and International Organizations, 17 Nw. J. Int'l L. \& Bus. 398, 442 (1996-1997) (characterizing agreements relating to services and intellectual property as part of "global package deals" negotiated within the GATT/WTO). In a sense, human rights treaties are also "package deals," a fact illustrated by the different sets of rights or different formulations of rights in agreements covering the same subject matter. See, e.g., Helfer, supra note 1, at 301-02 (comparing the civil and political rights provisions of the ICCPR and the European Convention). But such packages are restricted to the protection of individual liberties or group rights and are not linked to wholly unrelated subjects of international regulation. In addition, the WTO treaties do not permit state-specific reservations while human rights conventions usually do. See Final Act, supra note 18, art. XVI, para. 5.

239. Rose-Marie B. Antoine, Opting Out from the Optional Protocol-ls This Inhumane?, 3 Caribbean L. Bull. 28, 37 (1998) (noting claims by others that Pratt decision was an example of judicial imperialism).

240. Sinimons, Death Penalty, supra note 176, at 10; see also Bryan, supra note 149, at 197-98 \& nn. 129-130 (collecting statements by Caribbean judges that Privy Council's death penalty cases "did not conform to the judicial reality of the Caribbean region"); De 
The explanatory power of this optic is uncertain, however. Had Caribbean states merely been seeking an excuse to generate the regional political support necessary to sever links to a court steeped in the values of the old empire, they could easily have done so immediately after the Pratt case. Guyana had already chosen this route, and proposals for other states to follow suit had been made repeatedly since the early days of independence. ${ }^{241}$ lnstead, they chose as a first best strategy to expedite petitions to the human rights tribunals but retain appeals to the court. By doing so, Caribbean governments acknowledged the Privy Council's legitimacy and signaled their willingness to persuade the Law Lords that Pratt was erroneous as a principle of Caribbean constitutional theory and unworkable as a rule of.Caribbean criminal justice.

The judicial imperialism argument acquires greater force from the Privy Council's response to the governments' requests for accommodation. The court refused to acknowledge the clear evidence that Pratt's inflexibility had made it impossible for Caribbean states to permit human rights petitions to be heard within a reasonably deliberative period of time. Instead, it increased the strictures of its death row jurisprudence, invalidating the time limits the states had sought to impose on the tribunals and staying executions while petitions were pending. Far from adopting an incremental approach to introducing a new legal norm, the court's actions forced the norm upon a resistant legal and political culture. Even for established national courts, this approach might be criticized as politically inastute; but it was especially poor politics for a postcolonial court adopting a new rule that mapped perfectly onto a legal fault line dividing former colonies from the old empire. ${ }^{242}$

What predictive power does this imperial story have for relationships between national court judges and national political actors outside of the British Commonwealth? Given its sui generis postcolonial status, the Privy Council's role in promoting the backlash seems minimally relevant to national courts whose constitutional review functions are firmly anchored in their domestic political structures. There are, however, in the Privy Council's missteps important lessons for the increasing number of national courts engaging in a dialogue with foreign and international

La Bastide, supra note 150, at 407-08 (discussing effect of Privy Council rulings on Caribbean courts).

241. See supra notes $146,148$.

242. This analysis also implies that, whatever its formal powers, the Privy Council may in fact lie somewhere between a domestic court and a supranational tribunal. Its failure to perceive this hybrid status provides further insight into the causes of the backlash. The court's inflexible death row phenomenon rulings suggest that it viewed itself as a true domestic court with the ultimate power to say what the law is and to compel governments to act. A supranational tribunal would have been more circumspect, proceeding incrementally and flexibly because it could not assume compliance and had to rely instead on the persuasive power of its reasoning. The Privy Council's status is also relevant in assessing the case study's implications for international relations theory, a subject addressed in infra Part IV.C. 
jurists over human rights and constitutional norms. ${ }^{243}$ Courts participating in this growing trend toward "judicial globalization" permit their domestic jurisprudence to be shaped by outside influences and seek to harmonize-or at least reconcile-domestic, foreign, and international standards. ${ }^{244}$ Although many judges and commentators have praised this development, others, most notably in the United States, have questioned its legitimacy. ${ }^{245}$

When courts incorporate international norms into their domestic law, either directly (by giving a treaty direct effect) or more obliquely (by interpreting domestic norms consistently with a state's international commitments or by engaging in a dialogue with supranational tribunals that review those commitments), they augment a treaty's delegation variable by establishing themselves as potential enforcers of treaty norms. As several international relations scholars have noted, governmental actions are most constrained when international agreements are highly "embedded" in domestic legal systems and can be enforced by autonomous national courts. ${ }^{246}$ Sometimes governments acquiesce in this approach, in effect agreeing that domestic judges should serve as helpmeets for compliance. But where judges incorporate international norms on their own authority, the possibility of overlegalization increases.

243. See Claire L'Heureux-Dubé, The Importance of Dialogue: Globalization and the International Impact of the Rehnquist Court, 34 Tulsa L.J. 15, 16 (1998) (Justice of the Canadian Supreme Court stating that " $[\mathrm{m}]$ ore and more courts, particularly within the common law world, are looking to the judgments of other jurisdictions, particularly when making decisions on human rights issues"). For other examples of national courts in the Americas, Africa, and Asia following or carefully consulting the jurisprudence of human rights tribunals, see Slaughter, Judicial Globalization, supra note 16, at 1109-12 (European, South African, and Zimbabwean courts, and decision of Privy Council in Pratt); Developments in the Law-International Criminal Law, The International Judicial Dialogue: When Domestic Constitutional Courts Join the Conversation, 114 Harv. L. Rev. 2049, 2052-59 (2001) [hereinafter Developments in the Law] (Canadian, Indian, South African, and Zimbabwean courts). Somewhat ironically, these commentators cite the Privy Council's decision in the Prall case as a salutary example of the ways in which judges consult foreign and international judicial decisions to interpret domestic laws. See Slaughter, Judicial Globalization, supra note 16, at 1110; Developments in the Law, supra, at 2054.

244. Slaughter, Judicial Globalization, supra note 16 , at 1104.

245. Compare, e.g., Atkins v. Virginia, 122 S. Ct. 2242, 2250 n.21 (2002) (holding that the execution of mentally retarded defendants violates the Eighth Amendment of U.S. Constitution, and citing as persuasive evidence of a "consensus" against such executions the "overwhelming[] disapprov[al]" of "the world community"), with id. at 2254 (Rehnquist, C.]., dissenting) ("[I]f it is evidence of a national consensus for which we are looking, then the viewpoints of other countries simply are not relevant."); see also Knight v. Florida, 528 U.S. 990, 990-91 (1999) (Thomas, J., concurring in the denial of certiorari) (rejecting reliance by Justices Breyer and Stevens on foreign and international law sources to support defendant's claim that death row phenomenon violated Eighth Amendment's ban on cruel and unusual punishment).

246. Keohane et al., supra note 47 , at 467 . 
Although the case study confirms that it can be risky for judges to act as domestic "transmission belt[s]" 247 for international or foreign legal concepts, the risks will surely vary from jurisdiction to jurisdiction. In the case of the Commonwealth Caribbean, the risks were particularly great because of the Privy Council's colonial legacy and the potential for resistance to judicial rulings that domesticated legal concepts taken from the old empire. Similar concerns are likely to arise in dualist jurisdictions that strictly separate national and international law or limit the role of courts in enforcing international commitments, ${ }^{248}$ even if they do not cause the kind of radical judicial restructuring that occurred in the Caribbean. Conversely, where judicial consultation of foreign and international legal sources is a constitutional mandate (as in South Africa ${ }^{249}$ ), resistance to a judgment that relies on those sources is likely to be weak. Perhaps the most delicate balancing will be required of courts in states transitioning toward greater permeability to international influence, as is now occurring in the United Kingdom after Parliament's enactment of legislation incorporating the European Convention into domestic law. ${ }^{250}$

\section{The Caribbean Backlash as Overlegalization of International Law}

A third optic, one that draws upon but extends the insights of the previous two, concerns the Privy Council's overlegalization of Caribbean governments' treaty commitments. Consider first the effect of the court's death row rulings on each of the three legalization variables. ${ }^{251}$ The court increased the obligation of the treaties in two ways: first by fixing a domestic constitutional standard-the five-year execution window-by reference to the international petition system, and later by prohibiting governments from executing defendants while their petitions were pending. It increased the treaties' precision by particularizing the content of the degrading punishment norm shared by both international and domestic instruments. And it enhanced delegation by urging states to respect the decisions of the human rights tribunals and encouraging capital defendants to file petitions with them, thereby increasing the likelihood

247. Levit, supra note 58 , at 329 .

248. See generally John H. Jackson, Status of Treaties in Domestic Legal Systems: A Policy Analysis, 86 Am. J. Int'l L. 310, 314-19 (1992) (exploring differing roles of treaties in monist and dualist legal systems).

249. S. Afr. Const. ch. $2, \S 39(1)$ (b) (directing courts and tribunals to "consider intemational law" when interpreting the Bill of Rights); see also id. ch. 14, $\$ 233$ (directing courts to interpret legislation consistently with international law whenever reasonably possible).

250. See, e.g., Chris Ryan, Human Rights and Intellectual Property, 23 Eur. Intell. Prop. Rev. 521, 523-25 (2001) (discussing recent intellectual property decisions responding to Human Rights Act of 1998, which made the European Convention directly enforceable in courts in the United Kingdom).

251. See supra Part 1.A (explaining the three criteria-obligation, precision, and delegation-by which legalized characteristics of international agreements may be measured). 
that those petitions would later result in commutation of their sentences. In each instance, the Privy Council expanded the legalized quality of the Caribbean governments' human rights obligations. What began as agreements with both hard and soft law elements became much harder law in practice. What were initially international recommendations with no binding force were transformed into decisions with practical binding effect.

The Privy Council's actions also engendered both types of overlegalization identified in this Article. ${ }^{252}$ On the one hand, by effectively abolishing capital punishment where the treaties did not require abolition, the court altered the terms to which Caribbean nations had consented when they first ratified the treaties. ${ }^{253}$ This change created significant domestic opposition to both the tribunals and the Privy Council and generated strong domestic pressures in favor of exit. On the other hand, the Privy Council engendered overlegalization by improving enforcement opportunities unrelated to capital punishment itself. Putting the death penalty and the death row phenomenon to one side, Caribbean governments were granting capital defendants fewer rights than the treaties required. These treaty breaches-relating to unfair or delayed trials and appeals and inadequate conditions of detention-were revealed in the numerous nonbinding decisions the human rights tribunals issued after reviewing petitions from capital defendants. ${ }^{254}$ ln many cases, the tribunals recom-

252. See supra Part I.D (discussing difference between overlegalization that changes initial treaty bargains and overlegalization that improves enforcement opportunities).

253. See supra Part III.A (discussing the Caribbean backlash as a capital punishment dispute).

254. See, e.g., Lamey v. Jamaica, Cases 11.826, 11.843, $11.846 \& 11.847$, Inter-Am. C.H.R. 996, 1071-72, 231-37, OEA/ser.L/V/II.111, doc. 20 rev. (2000), available at http:/ /www.cidh.org/annualrep/2000eng/ChapterlII/Merits/Jamaica.11.826.htm (on file with the Columbia Law Review) (violations of Articles 5(1) and (2), and 1(1) of the American Convention based on mandatory nature of death penalty, delayed and unfair trial procedures, lack of legal aid, and conditions of detention on death row); Morgan v. Jamaica, Communication No. 720/1996, U.N. GAOR, Hum. Rts. Comm., 54th Sess., Supp. No. 40 vol. 2, at 221, U.N. Doc. A/54/40 (1998), available at http://www.unhchr.ch/tbs/ doc.nsf/(symbol) /472d043ca55dd6b180256714004008e8? opendocument (on file with the Columbia Law Review) (finding violation of Article 10(1) of the ICCPR based on inadequate conditions of detention, including lack of medical treatment); Morrison v. Jamaica, Communication No. 635/1995, U.N. GAOR, Hum. Rts. Comm., 53d Sess., Supp. No. 40 vol. 2, at 123-25, U.N. Doc. A/53/40 (1998), available at http://www.unhchr.ch/tbs/doc. nsf/(symbol)/dbe98945ec059398802566d5003b510d?opendocument (on file with the Columbia Law Review) (violations of Article 9(2) and (3), Article 14(3)(c), Article 10(1), and Article 7 (1) based on defendant not being informed of the charges against him until three or four weeks after his arrest, not being tried until two and a half years after arrest, and being ill-treated in custody); Smart v. Trinidad \& Tobago, Communication No. 672/ 1995, U.N. GAOR, Hum. Rts. Comm., 53d Sess., Supp. No. 40 vol. 2, at 149, U.N. Doc. A/ 53/40 (1998), available at http://www.unhchr.ch/tbs/doc.nsf/(symbol)/1990c66b9a 892223802566d4003cb607?opendocument (on file with the Columbia Law Rrview) (violations of Article 9(3) and Article 14(3)(c), based on two-year lag between arrest and trial). See generally Henry v. Jamaica, Communication No. 230/1987, U.N. GAOR, Hum. Rts. Comm., 47th Sess., Supp. No. 40, at 210, 218, U.N. Doc. A/47/40 (1991), available at 
mended that the defendants' death sentences be commuted. ${ }^{255}$ Prior to Pratt, Caribbean governments mostly ignored these recommendations. ${ }^{256}$ After Pratt, the Privy Council required the governments to commute death sentences whenever appellate and international review procedures exceeded five years. By imposing the same remedy for domestic law violations of the degrading punishment ban that the tribunals had recommended for these other treaty breaches, the court effectively ended the governments' ability to shirk compliance with their human rights commitments.

As this discussion reveals, however, the overlegalization produced by the Privy Council's rulings occurred indirectly and thus requires a more nuanced analysis. Had the court sought to increase the legalized quality of the obligation and delegation variables in a straightforward way, it could have instructed Caribbean governments that the human rights tribunals' recommendations were henceforth to be treated as binding. Similarly, the clearest method for the court to increase the precision variable would have been to interpret the treaties as themselves requiring a definite time limit on death row detention. ${ }^{257}$ The Pratt case adopted neither of these direct approaches. Instead, the Privy Council interpreted a parallel provision of domestic law in a way that indirectly augmented the treaties' legalization levels and allowed litigants and advocates to use the petition system strategically to effectively abolish capital punishment.

The Privy Council's indirect approach to legalization should hardly be surprising, however. As a formal matter, the court's interpretation of Caribbean constitutional texts rather than treaties conformed to the longstanding British rule that treaties can become binding as domestic law only through parliamentary enactments. ${ }^{258}$ Any attempt by the court to disregard this settled rule and augment the tribunals' authority directly would have been politically unpalatable to Caribbean governments. But it would also have ceded to the tribunals control over how to interpret and apply the degrading punishment norm and diminished the court's

http://www.unhchr.ch/tbs/doc.nsf/(symbol)/91167d85d50848abcl256aaee0049fa3b? opendocument (on file with the Columbia Law Review) ("In capital punishment cases, the obligation of States parties to observe rigorously all the guarantees for a fair trial set out in article 14 of the Covenant admits of no exception.").

255. See, e.g., Morgan, U.N. Doc. A/54/40, at 222 (recommending commutation of death sentences); Smart, U.N. Doc. A/53/40, at 149 (same); Lamey, Cases 11.826, 11.843, 11.846 \& 11.847, 1nter-Am. C.H.R. at 1072, OEA/ser.L/V/Il.111, doc. 20 rev. (same).

256. See supra note 190 (citing cases illustrating governments' refusal to comply with tribunals' recommendations or requests for interim measures).

257. Recall that in the decisions preceding the Privy Council's Pratt decision, the U.N. Human Rights Committee rejected the death row phenomenon as a violation of the ICCPR, whereas the 1nter-American Commission appeared to treat it as a breach of the American Convention (although without indicating the maximum period of time that a defendant could be detained on death row). See supra Part I1.B.2.

258. See Lewis v. Attorney Gen. of Jam., [2001] 2 A.C. 50, 83-84 (P.C. 2000) (appeal taken from Jam.). 
ability to tailor the Caribbean legal landscape to its own conceptions of criminal justice.

The Privy Council's actions illustrate that the incorporation of international norms or international review procedures into domestic law is one important pathway by which national courts can increase a treaty's legalization levels. Although the Privy Council achieved this increase indirectly, the combined effect of its decisions fundamentally altered the legalized character of the treaties. And, unlike legalization trends elsewhere, Caribbean governments actively resisted an evolution limited to a single issue for which domestic opposition to change was exceptionally strong.

Equally important, the Privy Council mismanaged the integration of domestic and international legal systems that the Pratt case required. Instead of holding fast to a rigid rule, the court could have endorsed the death row phenomenon in principle on the egregious facts of Pratt but not imposed a five-year time limit for all future executions. In this way, the court could have fleshed out incrementally the contours of the degrading punishment norm in subsequent cases, tempering it to the realities of the region's criminal justice system and to a more realistic assessment of the review periods required by the human rights tribunals. Had the Privy Council adopted this course, it might have avoided the backlash altogether.

When filtered through this lens, the case study provides a cautionary lesson in the perils of overlegalization. It suggests that states intentionally design treaty regimes with both hard and soft law components precisely because they are wary of relinquishing their sovereignty and foresee advantages in retaining flexibility when unanticipated events occur. ${ }^{259}$ Judges who modify these conscious regime design choices risk a backlash, particularly where they advance legalization too far or too fast, or without the tacit support of a state's political actors. ${ }^{260}$ In short, regime design matters, and governments may actively resist efforts by international or national jurists to create more deeply legalized commitments or more stringent review procedures after they have signed on to a treaty.

\section{Assessing Competing International Relations Theories in Light of the Caribbean Treaty Denunciations}

In addition to the insights generated by the three optics discussed in the previous Part, the Caribbean case study can be used to assess the realist, ideational, and liberal international relations theories identified in Part I. This Part first reviews the hypotheses that each theory would apply to evaluate the case study and then explores the extent to which those

259. See supra Part I.D.

260. Cf. Goldstein \& Martin, supra note 20, at 621 ("If enforcement is too harsh, states will comply with trade rules even in the face of high economic and political costs, and general support for [trade] liberalization is likely to decline."). 
hypotheses explain the events in the Commonwealth Caribbean. In assessing the predictive power of each theory, this Part portrays a richer and more nuanced picture than would a formal analysis of international legal rules alone. It thus adds to the broader debate between international legal scholars and political scientists over how the legalization of international norms affects states' conduct.

\section{A. Assessing Realist Theory}

Recall that realist theories of international relations emphasize the interests of powerful states in pressing weaker states for or against compliance with human rights norms. According to realists' focus on interstate bargaining power, both noncompliance with international commitments and exiting from a treaty are less likely if powerful nations actively oppose such conduct, and more likely if such states support or acquiesce in treaty-inconsistent behavior. In the Caribbean, the two powerful states able to influence the domestic policies of governments in the region are first, the United States, and second, the United Kingdom (and, more broadly, the European Union, of which it is a member). As is explained below, these states adopted divergent positions with respect to Caribbean human rights practices and Caribbean governments actively and successfully resisted any external pressures.

Consider first the United States. Although the United States exerts significant economic and political influence in the Caribbean, ${ }^{261}$ in light of its domestic use of the death penalty and its opposition to international efforts to abolish capital punishment, it was hardly likely to challenge the Caribbean governments' denunciations. ${ }^{262}$ Research for this Article has not revealed any attempt by the United States to oppose or protest Caribbean governments' treaty denunciations or their carrying out of death sentences. To the contrary, the State Department's country reports for Guyana and Trinidad \& Tobago contain only short and uncritical descriptions of the denunciations--including the governments' justifications for their actions-and the report on Jamaica is silent on the matter. ${ }^{263}$ Similarly, at a 1999 meeting of OAS government representa-

261. See Atkins, supra note 134, at 139-46, 166-67; Robert A. Pastor \& Richard D. Fletcher, Twenty-first Century Challenges for the Caribbean and the United States: Toward a New Horizon, in Democracy in the Caribbean, supra note 120, at 255, 264-72.

262. See, e.g., EU Drops Divisive Death Penalty Resolution at the UN, Agence France Presse, Nov. 18, 1999, available at LEXIS, Agence France Presse File (on file with the Columbia Law Review) (noting successful opposition by United States to EU-sponsored resolution in U.N. General Assembly calling on all states to suspend use of the death penalty); cf. Schabas, supra note 160, at 262 (labeling Jamaica, Trinidad \& Tobago, and United States "enthusiastic [death penalty] retentionist" states).

263. See 1999 Guyana Country Report, supra note 129; Bureau of Democracy, Hum. Rts. \& Lab., U.S. Dep't of State, 1999 Country Reports on Human Rights Practices: Jamaica (Feb. 25, 2000), available at http://www.state.gov/www/global/human_rights/1999_hrp_ report/jamaica.html (on file with the Columbia Law Review); Bureau of Democracy, Hum. Rts. \& Lab., U.S. Dep't of State, 1999 Country Reports on Human Rights Practices: 
tives commenting on Trinidad \& Tobago's denunciation, the United States delegation did not issue a condemnation but focused instead on granting regional tribunals additional resources to process cases expeditiously. ${ }^{264}$ The United States's position contrasts sharply with that of European governments, nine of which filed formal objections to the Caribbean denunciations of the Optional Protocal with the Secretary General of the United Nations. ${ }^{265}$

As for the United Kingdom, the Commonwealth Caribbean's close legal and political ties to that country allowed it to exert significant pressure on the region to abolish capital punishment. ${ }^{266}$ For its five dependent territories in the Caribbean, Britain abolished capital punishment outright in 1991.267 Such legislative action was not possible for independent Commonwealth members, but the British government used a variety of tools to urge Caribbean nations to halt executions. ${ }^{268}$ As Foreign Secretary Robin Cook stated in the late 1990s, "“[w]e need to use our diplomatic clout, our technical assistance and our human rights projects to persuade other countries not to use the death penalty." 269 Additional pressure came from the European Union, which in June 1998 made the

Trinidad \& Tobago (Feb. 2, 2000), available at http://www.state.gov/www/global/human_ rights/1999_hrp_report/trinidad.html (on file with the Columbia Law Review).

264. OAS News, Ambassadors Stress Need to Strengthen Regional Human Rights System, Sept.-Oct. 1999, available at http://www.oas.org/OASNews/1999/English/ September-Oct/art5.htm (on file with the Columbia Law Review) [hereinafter Ambassadors Stress Need].

265. Optional Protocol Ratification Chart, supra note 138 (noting objections of Denmark, Finland, France, Germany, ltaly, the Netherlands, Poland, Spain, and Sweden).

266. The ties of the Commonwealth were not as strong as might be expected, however. In particular, the United Kingdom had little success after the Second World War in maintaining control over local political structures in its former colonies, including control over their human rights policies. See Krasner, supra note 3, at 187 (noting inability of United Kingdom to maintain influence over local political structures "by contracting with local leaders regarding constitutional arrangements").

267. Shelley Emling, As Crime Rises, Caribbean Governments Turn to Hanging, Flogging, Austin American-Statesman, Oct. 17, 1998, available at LEXIS-NEXIS Academic Universe, Austin American-Statesman File (on file with the Columbia Law Review); see also Jim Loney, Caribbean States Resent British Pressure Over Gays, AAP Newsfeed, Feb. 20, 1998, available at LEXIS, AAP Newsfeed File (on file with the Columbia Law Review) ("Britain is pressing its current and former overseas territories to amend laws that ban homosexuality and allow capital and corporal punishment through much of the region."). Those possessions are Anguilla, British Virgin Islands, the Cayman Islands, Montserrat, and the Turks \& Caicos lslands.

268. Stephen Breen, Trinidad Begins Executing Killers, The Scotsman, June 5, 1999, at 12 (noting "strong pressure from Britain and Europe to abolish the death penalty"); Emling, supra note 267, at A23 ("For years, Britain has pressured [its] former colonies to abolish the death penalty, which the European Union has long opposed.").

269. See Maharaj, supra note 177, at 143 (quoting speech of British Foreign Secretary to Amnesty International). 
worldwide abolition of capital punishment a foreign policy priority. ${ }^{270}$ Under the new policy, EU officials expressed their opposition to the death penalty in demarches to Caribbean governments and allocated over half a million Euros for a legal assistance project to death row prisoners in the Caribbean. ${ }^{271}$

In response to these British and European pressures, Caribbean states were generally united in their resistance. The fifteen-member Caribbean Community (CARICOM) strongly opposed the EU's attempt to link the abolition of capital punishment to the provision of monetary aid, and Caribbean governments publicly defended the denunciations and use of capital punishment on sovereignty grounds. ${ }^{272}$ For example, at the 1999 OAS meeting mentioned above, the Ambassador of Barbados expressed concern that "powerful countries [we]re beginning to abrogate the right to make laws and establish the way in which smaller countries should conduct their business." 273

In sum, the case study supports the core realist claim that powerful states pressure weaker ones over the latters' compliance with international human rights commitments. In particular, the study illustrates that powerful states may increase pressure after weaker states have exercised their right to exit from a treaty. The efficacy of such coercive efforts is less certain, however. Although the precise pathways of power cannot be conclusively mapped, the case study suggests that coercion will fail where powerful states are divided and target states-even weak ones-unite in opposition. In the Caribbean, external pressure by European states was counterbalanced by tacit support of the United States and by a robust regional response that resisted conforming domestic criminal justice to international or foreign standards.

270. Council of the European Union, Guidelines to EU Policy Toward Third Countries on the Death Penalty, June 3, 1998, available at http://www.eurunion.org/ legislat/DeathPenalty/Guidelines.htm (on file with the Columbia Law Review).

271. Eur. Comm'n, Commission Staff Working Document: Report on the Implementation of the European Initiative for Democracy and Human Rights in 2000, at 15, available at http://europa.eu.int/comm/external_relations/human_rights/doc/ sec01_801.pdf (last visited Aug. 12, 2002) (on file with the Columbia Law Review) (noting financial support given to Penal Reform International to provide legal assistance to death row defendants in the Caribbean); Eur. Union, EU Annual Report on Human Rights 14, 60 (I999), available at http://europa.eu.int/comm/external_relations/human_rights/ doc/report_99_en.pdf (on file with the Columbia Law Review) (noting diplomatic contacts with The Bahamas, Jamaica, and Trinidad \& Tobago urging the abolition of capital punishment).

272. See Caribbean Community Rejects EU Link Between Aid and Ending Death Penalty, Cana News Agency, Feb. 27, 1999, available at LEXIS, BBC Worldwide Monitoring File (on file with the Columbia Law Review); see also Press Release, Organization of American States, Trinidad and Tobago Denunciation of OAS Human Rights Convention Effective Today, E-056/99ie (May 26, I999), available at http://www.oas.org/oaspage/ press2002/en/press99/0526991.htm (on file with the Columbia Law Review) (noting Trinidad \& Tobago ambassador's defense of the death penalty as within states' domestic jurisdiction, a statement supported by ambassador from St. Vincent \& the Grenadines). 


\section{B. Assessing Ideational Theory}

What lessons does the case study hold for ideational theory generally and the five-step spiral model of human rights change in particular? ${ }^{274}$ In the 1980s, Commonwealth Caribbean states were far advanced along the spiral. They were (with the exception of Guyana and Granada) liberal democracies that had ratified one and often multiple human rights treaties, including individual petition procedures. Human rights norms were embedded in their domestic constitutions, judicial review of rightslimiting government actions was generally robust, and local NGOs engaged in human rights advocacy. ${ }^{275}$ By the late 1990s, three Caribbean governments had denounced human rights petition procedures and all states in the region had resisted efforts by the Privy Council, European governments, and transnational advocacy networks to curtail or abolish their use of the death penalty.

Does the spiral model account for this sort of backlash? The model predicts that human rights changes are not always unidirectional, a hypothesis that the case study supports. But the model's creators also claim that most instances of repression or backlash will occur earlier in the spiral in states with far worse human rights records than those of the Commonwealth Caribbean. ${ }^{276}$ More importantly, in light of the "norm shift" that occurred in the Americas and elsewhere in the I980s and early 1990 s, some ideational scholars have asserted that "human rights norms have reached consensual ('prescriptive') status on the international level by now," such that states will no longer invoke national sovereignty to oppose charges of rights abuses and will be hard pressed to engage in "norm denial" when interacting with other state and nonstate actors. ${ }^{277}$

As the case study reveals, however, Caribbean governments engaged in precisely such norm denial and invocations of sovereignty notwithstanding their prior commitment to human rights treaties and institutions. ${ }^{278}$ This suggests that norm clashes (and even norm erosion) can occur at much later points in the spiral than ideationalists had predicted, well after a state has become a member of a human rights regime. More broadly, discursive efforts by state and nonstate actors to shame, cajole, and ultimately persuade Caribbean governments to comply with their treaty obligations were largely unsuccessful with respect to death penalty issues. To the contrary, support for capital punishment appears to have increased over time among both state actors and the public.

274. See supra Part I.C.1 (discussing the spiral model of human rights change).

275. See supra Part I1.A.2.

276. See supra notes $64-65$ and accompanying text.

277. See Risse \& Ropp, supra note 62, at 266.

278. Larry Rohter, 1n the Caribbean, Support Growing for the Death Penalty, N.Y. Times, Oct. 4, 1998, at Al 4 (noting statements by Attorney General of Trinidad \& Tobago that Inter-American Court's review of death penalty petitions was an "infringement of its sovereignty" and that "[t]he death penalty is not a human rights issue"). 
From an ideational perspective, what explains these events? ldeational studies note the existence of "blocking factors," domestic forces that prevent the spiral model from moving forward toward the final stage of rule-consistent behavior. These forces include "countervailing national norms and value structures which emphasize [ ] sovereignty and domestic cohesion more than human rights principles."279 Governments violating human rights commitments consciously appeal to these national norms and values structures "to increase their own legitimacy and to orchestrate a nationalist response to the increasing transnational network pressures." 280

Commonwealth Caribbean governments invoked two countervailing national norms in reaction to the flood of international petitions that followed the Pratt decision: (1) maintaining public order and security, and (2) upholding the domestic rule of law. ${ }^{281}$ The first justification resonated strongly with the Caribbean public, given the continuing high crime rates in the region and the popularity of using capital punishment to deter crime. ${ }^{282}$ The second justification resonated with legal elites, for it allowed governments to frame the issue as a binary choice between complying with the mandatory constitutional requirements of Pratt (itself grounded on the well-establislıed human rights principle barring degrading punishment), or the practices of international tribunals alleged to be incompatible with those requirements. ${ }^{283}$

Invoking these countervailing norms allowed Caribbean governments not only to amass popular support for their actions, but also to shore up regional backing for capital punishment and resistance to external pressures. When faced with demands from state and nonstate actors, Caribbean governments publicly and collectively reaffirmed each others' right to impose the death penalty even if that required denouncing inter-

279. Risse \& Ropp, supra note 62 , at 261 .

280. Id.

281. See Maharaj, supra note $I 77$, at 152-53.

282. See supra note $I 58$ and accompanying text.

283. In public statements that accompanied the denunciations, both Trinidad \& Tobago and Jamaica justified their actions by reference to the domestic constitutional constraints imposed by the Privy Council. See Ministry of Foreign Affairs, Republic of Trinidad and Tobago, Notice to Denounce the American Convention on Human Rights (May 26, 1998), available at http://www.oas.org/juridico/english/Sigs/b-32.html (on file with the Columbia Law Review); see also Simeon C.R. McIntosh, Cruel, Inhuman and Degrading Punishment: A Re-Reading of Pratt and Morgan, 8 Caribbean L. Rev. 1, 4 (1998) ("The Jamaican Government has . . . explained its decision [to denounce the Optional Protocol] as one of 'agony' over how to respect Jamaica's various human rights treaty commitments, and yet, at the same time, have death penalty decisions carried out within five (5) years, as required by Pratt and Morgan."); Press Release, Organization of American States, Trinidad and Tobago P.M. Tells OAS That Death Penalty is Not a Human Rights Issue (Sept. 24, 1999), available at http://www.oas.org/OASpage/press2002/en/Press99/ 092399.htm (on file with the Columbia Law Review) (noting that treaty denunciations were required for continuing to impose capital punishment consistent with state's constitutional obligations). 
national agreements. For example, in January 1999, attorneys general from twelve Caribbean states urged their governments to denounce the human rights agreements and reratify them with death penalty reservations. ${ }^{284}$ Similarly, at a meeting of the OAS in June 1998, Caribbean foreign ministers broke from the rest of the OAS Assembly to express their unanimous support for Trinidad's decision to denounce the American Convention. ${ }^{285}$

These collective affirmations of regional autonomy fit with ideational theory, but in a strikingly different way than studies had predicted. Ideational scholars assert that the states "most susceptible to network pressures are those that aspire to belong [or already belong] to a normative community of nations," 286 or "an emerging community of liberal states." 287 The Commonwealth Caribbean, a region of liberal democracies with a common political, legal, and historical identity, fits the definition of such a community. But unlike larger groupings of liberal states, Caribbean nations privileged a particular interpretation of human rights norms that excluded capital punishment. Ideationalists predicted that membership in a liberal or normative community would figure prominently in whether a state was susceptible to external pressure for human rights changes, and the case study supports this. But whereas ideationalists believed that such membership would favor compliance with international norms, the case study demonstrates that such membership can also weigh against compliance. Stated another way, membership in a normative community of Commonwealth Caribbean states reduced, rather than enhanced, states' vulnerability to external pressure and prevented them from being relegated to an "outgroup" of human rights violators. ${ }^{288}$

Two facets of the case study help to explain the strength of Caribbean resistance. The first relates to the contested and evolving nature of the human rights norms surrounding capital punishment. As explained above, a clear norm shift occurred in the years following Caribbean states' ratification of the human rights agreements. ${ }^{289}$ Rather than challenging the death penalty directly, capital defendants reframed death row detention as a distinct human rights problem. Once the Privy Council accepted this argument, Caribbean states were forced to operate under constitutional time constraints in tension with allowing defendants to petition the human rights tribunals.

284. Amnesty International: USA Midnight Shame: USA Executes Child Offender, Feb. 5, 1999, available at LEX1S, M2 Presswire File (on file with the Columbia Law Review).

285. Caribbean: Caribbean States Support Trinidad and Tobago Human Rights Stance at OAS, BBC Monitoring Summary of World Broadcasts: Africa, Latin America and the Caribbean, June 6, 1998, at L/2; Row Over Decision to Quit Convention; Government Removes Obstacle to Death Penalty, Latin Am. Regional Rep., June 16, 1998, available at LEXIS, Latin American Newsletters File (on file with the Columbia Law Review).

286. Keck \& Sikkink, supra note 54, at 29.

287. Risse \& Sikkink, supra note 51, at 24.

288. Id. at 27 .

289. See supra notes $223-224$ and accompanying text. 
Ideational studies predict that efforts to promote domestic change will depend upon the issues around which advocacy strategies coalesce. Although physical harm to vulnerable or innocent individuals is a compelling subject for transnational pressure, "what constitutes bodily harm and who is vulnerable or innocent may be highly contested."290 The case study supports this issue-specific sensitivity. In particular, the sharp contestations over the human rights dimension of death row detention (and the Caribbean-European fault line around which divisions formed) allowed Caribbean states credibly to engage in norm denial after the norm shift occurred, and to use that denial to justify their withdrawal from the treaties. ${ }^{291}$

The second feature of the case study that implicates ideational theory concerns the pressure from nonstate actors. As the petition filing data described in Part II demonstrates, British law firms and organizations such as Interrights (both of which fit the definition of transnational advocacy networks) were especially active in bringing cases to the human rights tribunals following the Pratt decision. ${ }^{292}$ Indeed, they were involved with a large majority of petitions filed by defendants on death row in the Caribbean. Not only were these petitions effective in delaying executions (often beyond the Privy Council's five-year window), but they also raised a slew of substantive challenges to capital sentences. Thus, nonstate actors imposed ample pressure on Caribbean governments "from above" to commute capital sentences in individual cases.

Pressure "from below" was inadequate, however. Although some Caribbean human rights organizations had forged links with transnational allies, local public opinion overwhelmingly favored capital punishment. Other than the Catholic Church, few domestic nonstate actors favored abolishing the death penalty. ${ }^{293}$ The relatively thin support for abolition among domestic nonstate actors supports the core ideational claim that "[e]ffective [transnational advocacy] networks must involve reciprocal information exchanges, and include activists from target countries as well as those able to get institutional leverage." ${ }^{294}$ In the absence of such local pressure, the boomerang pattern of influence-in which nonstate actors pressure governments from both above and below-is unlikely to emerge.

290. Keck \& Sikkink, supra note 54, at 27.

291. Cf. Risse \& Sikkink, supra note 51, at 24 ("[1]t is possible that denial and backlash is a normative phase particular to a period in which new international norms have emerged, but when they are still strongly contested internationally.").

292. See supra note 196 and accompanying text and Figure 4.

293. See O'Neill, supra note 152, at 194 (stating that Catholic church provided the only "visible dissent" to Caribbean death penalty policies); State Killing, supra note 156, at 5 ("The community working against the death penalty in the [English speaking Caribbean], while dedicated, is small and faces regular physical threats and vilification in the media."); see also supra note 158 and accompanying text.

294. Keck \& Sikkink, supra note 54, at 28-29. 
These two features-an increase in legalization focused solely on capital punishment and the absence of domestic groups favoring abolition-worked in tandem to remove pressures in favor of treaty compliance. Had the rise in legalization levels been distributed across a broad range of issues, local human rights advocates might have had stronger incentives to challenge the governments' actions. After all, a breach of one treaty right could have increased the risk that the governments would violate other rights. But the distinct treatment of capital punishment allowed the boomerang pattern of influence to break down and subjected the issue to blocking factors not applicable to human rights as a whole.

In sum, the case study's support for ideational hypotheses is equivocal. On the one hand, the mechanisms by which principled ideas are transmitted, including the role of transnational advocacy networks, the focus on norm evolution, and the tactics governments use to block human rights advances, provide important insights that help to explain the Caribbean backlash. Yet the case study calls into question the largely progressive and sanguine narrative of human rights change that ideational scholars have sketched. Ideational theory seems especially weak in its prediction that norm denial and rule violations are unlikely to occur among states that are fairly far advanced in the spiral of change. As the case study demonstrates, rights backlashes can occur even among liberal democracies that in the main are committed to protecting individual liberties and that are active players in human rights regimes.

\section{Assessing Liberal Theory}

To assess the case study's implications for liberal international relations theory, this Section first addresses liberal hypotheses regarding a state's regime type as an independent variable in predicting the nature of its relationships with international regimes. It then considers the case study's implications for liberal theories concerning compliance with treaty commitments and evolution of human rights regimes, including the critical variables of a treaty's incorporation into national law, the impact of supranational adjudication, and the role of private parties in enforcing international obligations.

1. Differences in Regime Type as an Explanatory Variable. - For liberal scholars, the regime type of a state is a critical predictor of how it will interact with international regimes. ${ }^{295}$ At this level of analysis, the case study provides provocative, although ultimately inconclusive, new evi-

295. Some liberal scholars have asserted that liberal states are more likely than nonliberal states to comply with thejr international commitments. See, e.g., Simmons, Legalization, supra note 46, at 594-95 (summarizing theories regarding propensity of liberal democratic states to comply with their international commitments). Recent studies have become increasingly nuanced, however, using more fine-grained evidence to differentiate among different types of liberal states and among liberal democracies, rule of law societics, and nonliberal regimes. See supra notes 45-47. For a more detailed discussion of liberal theory, see supra Parts I.B, I.C.2. 
dence. Jamica and Trinidad \& Tobago-two of the three states that denounced human rights treaties and petition procedures-are liberal democracies, with long-standing commitments to liberal values, including independent judicial review and the protection of civil liberties. The third state, Guyana, is a regional outlier. It is a transitional democracy, struggling to overcome the consequences of its autocratic and socialist post-independence past, whose respect for liberal institutions and individual rights is only recently and shallowly entrenched.

Despite these differences in regime type, all three states denounced human rights treaties. Moreover, the two liberal governments denounced international regimes more comprehensively than did their nonliberal neighbor, and they were far more assertive in defending their actions domestically and internationally and in criticizing the tribunals. ${ }^{296}$ These facts cut against the liberal claim that liberal democracies are more likely than other states to engage with international institutions and adhere to their international commitments.

Yet a contrary inference is also possible. Trinidad \& Tobago and Jamaica could simply have ignored their treaty commitments in practice while nominally remaining parties to the treaties. By following the formal denunciation procedures that the treaties themselves authorized, the two governments demonstrated a form of respect for human rights regimes rather than the "[o]rganized [h]ypocrisy" that some international relations scholars have associated with insincere treaty ratifications. ${ }^{297}$ In addition, the two liberal states had nonfacetious justifications for their actions, including the Privy Council's misperceptions about the time required to review death row petitions, the contested treatment of the death row phenomenon as a human rights issue, and the governments' attempt to expedite the tribunals' review periods prior to denouncing the treaties. Whatever one thinks of these rationales, they are far more persuasive than the justifications offered by nonliberal Guyana, which was not bound by the strictures of Pratt and which denounced the ICCPR's Optional Protocol after the Human Rights Committee issued its first unfavorable decision against it. ${ }^{298}$

This interpretation should not be overstated, however. Both Trinidad \& Tobago and Jamaica often refused to implement the tribunals' recommendations even when they were parties to the treaties. And Trinidad openly flouted the internationally binding provisional measures orders of the Inter-American Court of Human Rights by hanging defendants who had filed petitions with the Inter-American Commission prior to

296. See supra Part II.B.6.

297. Krasner, supra note 3 , at 32 (noting lack of correlation between human rights treaty ratifications and respect for human rights norms).

298. See supra notes 2I4-217 and accompanying text. Guyana's denunciation might also be viewed as an attempt to show solidarity with its two regional neighbors, with whom it had been actively promoting a new Caribbean Court of Justice. See supra notes 225-227 and accompanying text. 
the effective date of the state's denunciation. ${ }^{299}$ This behavior contrasts sharply with the practice of other liberal democracies, particularly in Europe, which are far more respectful of international human rights tribunals. ${ }^{300}$

When the Caribbean region is viewed as a whole, however, additional evidence supporting the liberal regime type hypothesis emerges. The nine other liberal democratic members of the Commonwealth Caribbean did not denounce human rights treaties, although they were equally bound by the time constraints of Pratt and their attorneys general had called for denunciations. And two states in the region ratified human rights instruments after the Privy Council issued its ruling in late 1993, including Barbados which was considering denouncing the American Convention. ${ }^{301}$ Admittedly, the statistical evidence provided in Part II reveals that death row petitions filed against these other Caribbean nations were sparse, reducing the pressure to abrogate international review to meet the Privy Council's five-year timetable. ${ }^{302}$ Nevertheless, when viewed in the aggregate, the case study supports the inference that most liberal democracies in a region under strong pressure to change domestic criminal justice policies refrained from abrogating (and in two cases extended) their treaty commitments.

Finally, an important cautionary note about the robustness of the foregoing conclusions is warranted. The case study involves an extremely small data set of twelve sovereign states, ten of which qualify as liberal democracies and only three of which actually denounced human rights treaties. In addition, Commonwealth Caribbean nations other than the Bahamas, Jamaica, and Trinidad \& Tobago have small populations and even smaller death rows, ${ }^{303}$ making comparisons among states in the region difficult. Similarly, generalizing about the conduct of nonliberal

299. See supra notes $218-220$ and accompanying text.

300. See supra notes $17,82-83$ and accompanying text.

301. American Convention Ratification Chart, supra note 84 (noting June 4, 2000 acceptance of jurisdiction of Inter-American Court by Barbados); ICCPR Ratification Chart, supra note 84 (noting June 10, 1996 accession to ICCPR by Belize); see also Gutierrez, supra note 199 (reporting that Barbados may denounce American Convention).

302. See supra Figure 2.

303. See MichaeI Dorman, Caribbean Islands Battle Rising Crime, Newsday, Mar. 14, 1999, available at 1999 WL 8I62017 (on file with the Columbia Law Review) (citing Amnesty International report stating that there are "nearly 250 prisoners on death rows in the Caribbean," of which 104 were incarcerated in Trinidad \& Tobago, forty-seven were incarcerated in Jamaica, and forty were incarcerated in the Bahamas); Serge F. Kovaleski, Death Penalty Gaining Favor in Caribbean Isles; Rise in Violent Crime Sparks Public Outrage, Ft. Lauderdale Sun-Sentinel, Sept. 5, 1998, at 21 A, available at $1998 \mathrm{WL} 12827602$ (on file with the Columbia Law Review) (citing Amnesty International report stating that twenty-four prisoners were on death row in Guyana and nine prisoners were on death row in Belize); Richards, supra note 158 (stating that St. Lucia, with a population of less than 150,000 , had seven prisoners condemned to death); see also The World Almanac and Book of Facts, supra note 228, at 867-68 (listing populations of Conmonwealth Caribbean nations). 
states based solely on Guyana's conduct is problematic. That nation was the region's only long-standing nondemocracy, but it both ratified and withdrew from the Optional Protocol after a slow transition to democracy had commenced. Given these empirical limitations, it is impossible to determine with precision whether the case study supports or undermines liberal claims about the explanatory power of regime types.

2. Incorporation and Supranational Judicial Review as Explanatory Variables. - If the conclusions about the liberal regime type hypothesis are equivocal, the case study offers more definitive insights regarding the two variables of incorporation and supranational judicial review that liberal scholars (and others) have identified as central to promoting compliance with international commitments. As with the ECJ and ECHR, the critical interactions occurred among international tribunals, domestic courts, and private litigants, but the story that unfolded was far different from the one told in Europe. The puzzling question is why a de facto incorporation of international norms into domestic law and a domestic court's interactions with international tribunals produced not compliance but backlash.

The story begins with supranational judicial review, in which all three denouncing states had agreed to participate. That review, however, resulted in nonbinding recommendations by the two tribunals-recommendations that defending states often ignored. Supranational review (and the human rights violations it exposed) was thus only a weak constraint on governments seeking to impose death sentences, even if they did not always execute defendants while petitions were pending. Even in cases where states violated the treaties, governments could easily resist the tribunals' entreaties and ensure that their domestic laws remained unaltered. . $^{304}$

The Pratt case changed this legal landscape in crucial ways. First, it adopted a new human rights norm-the death row phenomenon-that was far more favorable to capital defendants than preexisting law and that imposed significant constraints on executions. Second, it signaled to Caribbean governments that the region's highest court considered supranational review to be a useful supplement to domestic appeals in capital cases, even while it acknowledged that the governments were not bound to commute death sentences if the tribunals so recommended. Third, the case publicized the existence of supranational judicial review to death row defendants and their advocates, raising hopes that the governments would give the tribunals' decisions the "weight and respect" the court believed they deserved. ${ }^{305}$

The most important aspect of Pratt, however, was its de facto incorporation of elements of international human rights regimes into domes-

304. See supra note 190 (discussing responses by Trinidad \& Tobago and Jamaica to decisions and recommendations of human rights tribunals).

305. Pratt v. Attorney Gen. for Jam., [19941 2 A.C. 1, 27 (P.C. 1993) (appeal taken from Jam.). 
tic law. This incorporation had both substantive and procedural dimensions. Substantively, the Privy Council endorsed as a matter of domestic constitutional law a claim that international tribunals had been wrestling with as a matter of treaty construction for several years: that prolonged death row detention was degrading or inhuman. lndeed, the court used international decisions as persuasive support for its ruling. In the process, the Privy Council validated the tribunals' own efforts to limit states' authority in capital cases.

But the procedural incorporation aspect of the Privy Council's ruling was even more striking. Pratt expressly considered petitions to human rights tribunals when deciding how much of a delay in carrying out executions was constitutionally permissible. In effect, the Privy Council fixed a domestic constitutional standard by reference to the international petition system. The court's subsequent death row decisions confirmed and extended this approach, striking down the time limits Trinidad and Jamaica had sought to impose on the tribunals and barring executions while the defendants' international petitions were under review. ${ }^{306}$

Consider the effect of these rulings on the authority of the human rights tribunals and the treaties they interpret. Here was a domestic court that appeared to be entering into a partnership with the tribunals, validating their efforts, promoting the filing of new cases by private parties, and even authorizing a remedy (binding provisional measures) that the tribunals themselves were powerless to impose. ${ }^{307}$ The practical effect of the court's rulings was to increase markedly the embeddedness of treaty rules and supranational review in domestic law. According to the liberal hypothesis discussed in Part 1.C.2, this should have resulted in greater compliance with international commitments, especially in states with independent judiciaries and a strong commitment to protecting individual liberties. For a time, this proved to be true. But this increased compliance with international norms quickly backfired as governments sloughed off both their treaty obligations and the Privy Council's review.

Can liberal theory account for this behavior? On the one hand, recent liberal scholarship rejects the claim that international regimes have an inherently expansionist character that precludes backlashes. ${ }^{308}$ 1t also asserts that governments do not always anticipate the domestic political consequences of participating in international regimes, particularly where such regimes include supranational tribunals to which private par-

306. Thomas v. Baptiste, [2000] 2 A.C. 1, 21, 24, 29 (P.C. 1999) (appeal taken from Trin. \& Tobago); Lewis v. Attorney Gen. of Jam., [2001] 2 A.C. 50, 85 (P.C. 2000) (appeal taken from Jam.).

307. In the case of the American Convention, the Inter-American Commission had the authority to ask the Inter-American Court of Human Rights to issue provisional measures binding as a matter of international law on any state accepting the Court's jurisdiction. In the Commonwealth Caribbean, only Trinidad \& Tobago (and, since June 2000, Barbados) could have been subject to such binding orders. American Convention Ratification Chart, supra note 84.

308. See Alter, supra note 16 , at 512-13. 
ties have access. ${ }^{309}$ These factors suggest that the evolution of international regimes is often difficult to predict and that later iterations of a treaty system are not necessarily superior to earlier ones. ${ }^{310}$ At the same time, however, scholars have asserted that high levels of incorporation and supranational judicial review "make it much more difficult for governments to retreat from their legalized commitments when the [unanticipated political] consequences become clear." 311 That result plainly did not occur in the Commonwealth Caribbean.

A related liberal hypothesis helps to explain why the treaty denunciations occurred notwithstanding the domestic incorporation of international norms. In explaining the success of the ECJ and ECHR in achieving increased levels of treaty compliance, liberal scholars have stressed the links between supranational tribunals, national courts, and the private litigants who use domestic and international litigation to press for legal and political change. ${ }^{312}$ They have focused on how the incentives of each of these actors favored the forging of strong relationships between the judges, and how the mutual pursuit of self interest drove the expansion of the treaties. ${ }^{313}$

In the Commonwealth Caribbean, however, the self interest of each of these three actors was not mutually reinforcing. Instead, it exacerbated the clash between domestic and international legal systems and increased the political reaction against the supranational-domestic judicial partnership. Consider first the litigation incentives of capital defendants and their counsel. The timetable set by the Pratt case meant that death sentences could be overturned not only by convincing domestic courts that the government had violated a defendant's constitutional rights, but also by extending domestic and international review processes beyond the five-year window. Death row defendants and their counsel thus had strong incentives to file petitions with one or both tribunals and to convince the Privy Council to embed the international petition system in Caribbean domestic laws. The British law firms that represented the vast majority of Caribbean defendants before both the tribunals and the Privy Council were well situated to achieve these objectives. ${ }^{314}$

309. Keohane et al., supra note 47 , at $477-78$ (noting that state compliance with international commitments is enhanced where individuals and groups have direct access to international tribunals).

310. Cf. Goldstein \& Martin, supra note 20, at 630 (arguing that earlier and less legalized GATT may have been superior at achieving progressive liberalization of international trade to later, more legalized WTO).

311. Kahler, supra note 53 , at 682 .

312. See supra notes $82-83$ and accompanying text (discussing how European tribunals forged links with domestic courts and domestic litigants interested in seeking compliance with their rulings).

313. Burley \& Mattli, supra note 82 , at 60 (stating that "[t]he glue that binds this community of supra- and subnational actors is self-interest").

314. See Assistance for Prisoners, supra note 196 (discussing pro bono assistance provided to defendants in both judicial fora); see also supra Figure 4 (identifying 
From the tribunals' perspective, the large number of death row petitions provided fresh opportunities to enhance their authority. The cases allowed the tribunals to clarify the scope and content of the treaties, to publicize the petition procedures, and to exert pressure on governments to alter their treaty-incompatible practices. But exercising these functions requires time and resources, and the tribunals had insufficient quantities of both to review cases within the eighteen-month window the Privy Council had set. ${ }^{315}$ The result was that governments, rather than being shamed, cajoled, or persuaded into voluntarily implementing the tribunals' recommendations, strongly resisted the de facto partnership between the Privy Council and the tribunals that Pratt engendered.

The actions of the Privy Council also appeared to serve its rational self interest. During the 1980 s and early 1990 s, the court had begun to develop a more rights-protective jurisprudence and to engage in a dialogue with other national courts and supranational tribunals over the individual rights provisions common to both Caribbean constitutions and human rights treaties. ${ }^{316}$ Pratt continued this trend and thus ensured that the Privy Council would remain an important player in policing Caribbean criminal justice systems through its powers of constitutional review. Pratt also came at a time when other British territories and members of the Commonwealth were severing their links with the Privy Council. ${ }^{317}$ Given the active use of capital punishment in the Caribbean, accepting death row detentions as a form of degrading punishment ensured that the court would continue to have an active appellate docket and would not fall into desuetude.

In isolation, therefore, the behavior of each of these three actors appeared rational. Together, however, they made it impossible for Caribbean governments both to allow the international petition process to run its course and to carry out the executions that their citizens were clamoring for.

Two other aspects of the case study are relevant to this analysis of incentives. The first concerns whether the Privy Council should be treated as a domestic court. The Privy Council is nominally the Commonwealth Caribbean's highest court of appeal. But its location in London,

representation of Caribbean death row defendants by British law firms and advocacy groups).

315. This statement must be qualified for the lnter-American Commission, which expedited its review of Caribbean death row petitions filed in 1998 and 1999. See supra note 195 and accompanying text. The eighteen-month window would not, however, be adequate to permit defendants to petition two tribunals in succession. See supra note 189 and accompanying text.

316. See supra Part Il.A.3 and note 232 (discussing evolution of Privy Council's jurisprudence and collecting cases discussing decisions of international human rights tribunals).

317. These include, during the 1990s, Australia, Fiji, Hong Kong, Malaysia, and Singapore. New Zealand is also considering abolishing appeals to the Privy Council. De La Bastide, supra note 150 , at 402 . 
its staffing by British Law Lords, its colonial legacy, and the power of local governments to abolish appeals to it suggest that the Privy Council has a sui generis status somewhere between an international and a domestic court $^{318}$ In Europe, the national courts that were essential players in expanding international commitments were accepted parts of the domestic legal order. The Privy Council, by contrast, was a distant judicial body steeped in different legal culture. ${ }^{319}$ In this setting, it is not surprising that the Privy Council's death row rulings were perceived as externally imposed norms that did not receive the habitual acquiescence that even unpopular national court rulings receive in societies with independent judiciaries and commitments to the rule of law.

The second aspect of the case study that is relevant to actor incentives concerns the distributional effects of the Pratt decision and the international petitions it engendered. Liberal scholars have noted that the distribution of costs and benefits is relevant to how nonstate actors mobilize in the aftermath of supranational judicial rulings. ${ }^{320}$ They have theorized that successful pressure for compliance with such rulings is more likely where their benefits fall on a narrowly defined group (particularly a group that has previously mobilized in favor of policy change) but their burdens are more widely distributed. Conversely, countermobilization against implementing judicial decisions is more likely if the costs of compliance are more narrowly focused. ${ }^{321}$

An analysis of the distributional effects of the Caribbean death penalty cases helps to explain the backlash, although the effects do not precisely track scholars' predictions. The benefits of the human rights tribunals' death row decisions flowed to a relatively small group of individuals (convicted criminal defendants), but a group that was a highly disfavored segment of Caribbean society with little if any political clout. The burdens of these decisions (that is, the effects of reduced criminal penalties) were widely distributed, but they were also deeply felt because of the popular belief that tough criminal sanctions deterred violent crime. To the extent that benefits also accrued to nonstate actors and legal counsel advocating criminal justice reform or abolition of the death penalty, most of those actors were located outside of the Commonwealth Caribbean, limiting the political pressure they could exert on governments to implement the tribunals' recommendations.

In sum, the case study provides important support for the liberal hypothesis that linkages among international tribunals, domestic courts, and private litigants are critical to determining compliance with international commitments. But where most liberal studies have focused on how

318. Cf. Barry Phillips, Pratt \& Morgan v. Attorney-General for Jamaica, 88 Am. J. Int'l L. 775, 776 (1994) (Case Note) (stating that after Pratt, "the Privy Council could now be said to be developing into a human rights court for the British Commonwealth").

319. See supra Part III.B (discussing judicial imperialism by Privy Council).

320. See Alter, supra note I6, at 508.

321. Id. 
these linkages can expand the legalized nature of treaty systems or enhance compliance, the Caribbean case study reveals how these interactions can also cause a counterreaction against further legalization and compliance.

\section{Conclusion}

The Commonwealth Caribbean backlash against human rights regimes at first appears puzzling. Why would three governments that generally respect the rule of law, protect individual liberties, and support international treaty regimes denounce human rights agreements and withdraw from the jurisdiction of human rights tribunals?

At least in part, the answer lies in the overlegalization of the human rights commitments that these three states had undertaken. Overlegalization can occur where a treaty develops higher levels of obligation, precision, and delegation than existed when a state first ratified the treaty. In its overlegalized form, a human rights treaty constrains a government's ability to balance the protection of individual liberties against other pressing social concerns, and thus generates domestic opposition to compliance or pressure to revise or denounce the treaty. In the Commonwealth Caribbean, the Judicial Committee of the Privy Council indirectly enhanced the legalization levels of the 1CCPR and the American Convention when it interpreted domestic constitutional limitations on the maximum time defendants could spend on death row by reference to international human rights petition procedures. This interpretation effectively abolished the death penalty, a form of punishment that was overwhelmingly popular with the citizens of Guyana, Jamaica, and Trinidad \& Tobago to combat high rates of violent crime in those countries. When the governments could not reconcile this strong domestic preference for capital punishment with their international commitment to allow defendants to petition the human rights tribunals, they withdrew from the treaties.

Additional insights into the causes of the backlash are found in three competing international relations theories that seek to explain why states enter into and comply with human rights agreements. Each of the three theories-realist, ideational, and liberal-helps to explain why Commonwealth Caribbean states acted as they did. But events in the region also provide important new evidence to assess claims made by international relations theorists, to question some of their assumptions, and to challenge accepted hypotheses. In particular, the Caribbean backlash provides an unusual opportunity to test in a non-European setting the explanatory power of such variables as external pressure from powerful states, the persuasive pull of the idea of human rights, the incorporation of international agreements into domestic law, links between national and international jurists, and the role of domestic interest groups and transnational advocacy networks as constituencies for or against treaty compliance. 
Finally, if, as this Article suggests, the design of treaties matters to states and if treaties have a tendency to evolve toward higher levels of legalization or even overlegalization, scholars should broaden their scope of inquiry into the mix of hard and soft law elements that enhances states' compliance with their international commitments. In particular, scholars should consider when, how, and by whom legalization levels are modified, and the conditions under which linkages between domestic and supranational state and nonstate actors can expand compliance opportunities without eliciting hostile reactions from national governments. 